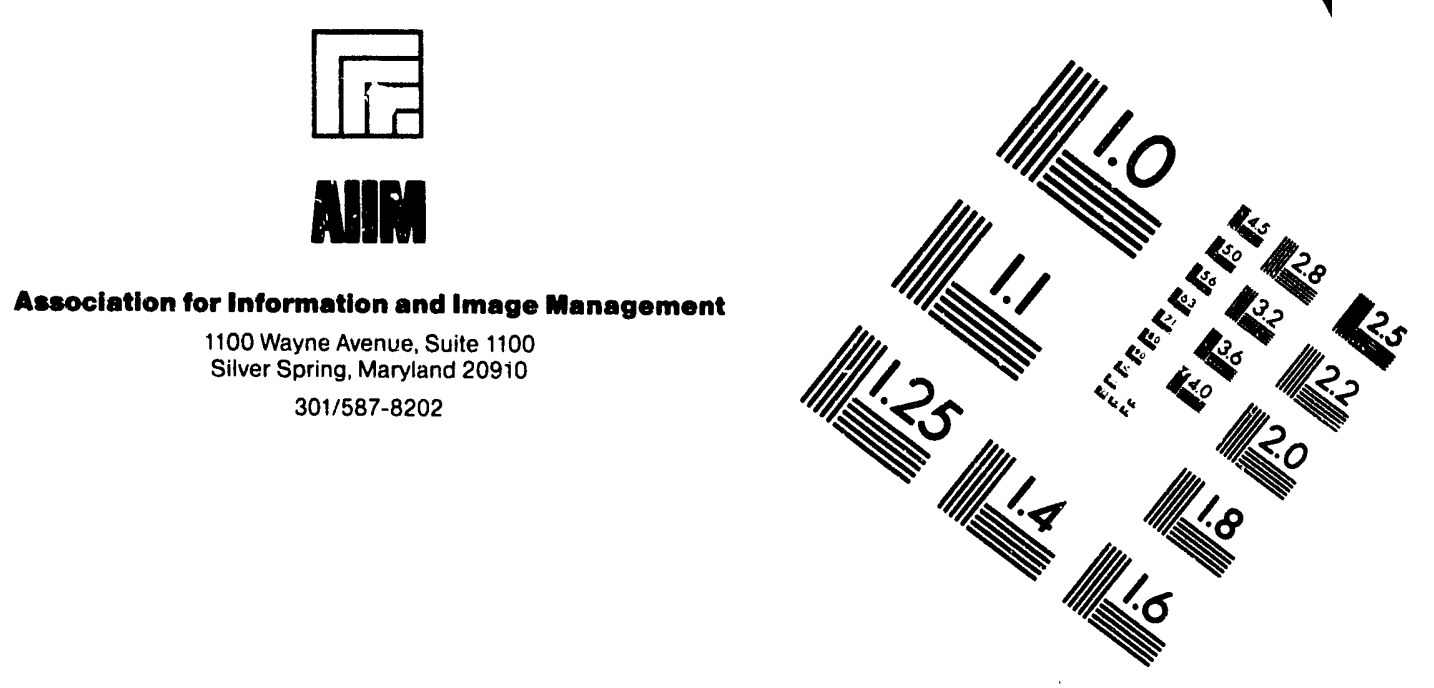

\title{
Centimeter
}

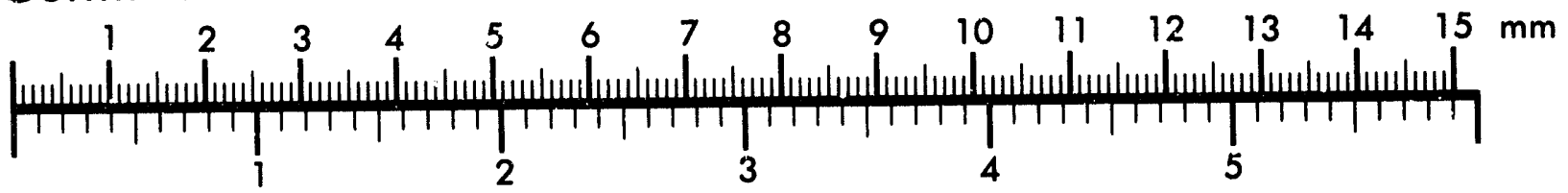
Inches
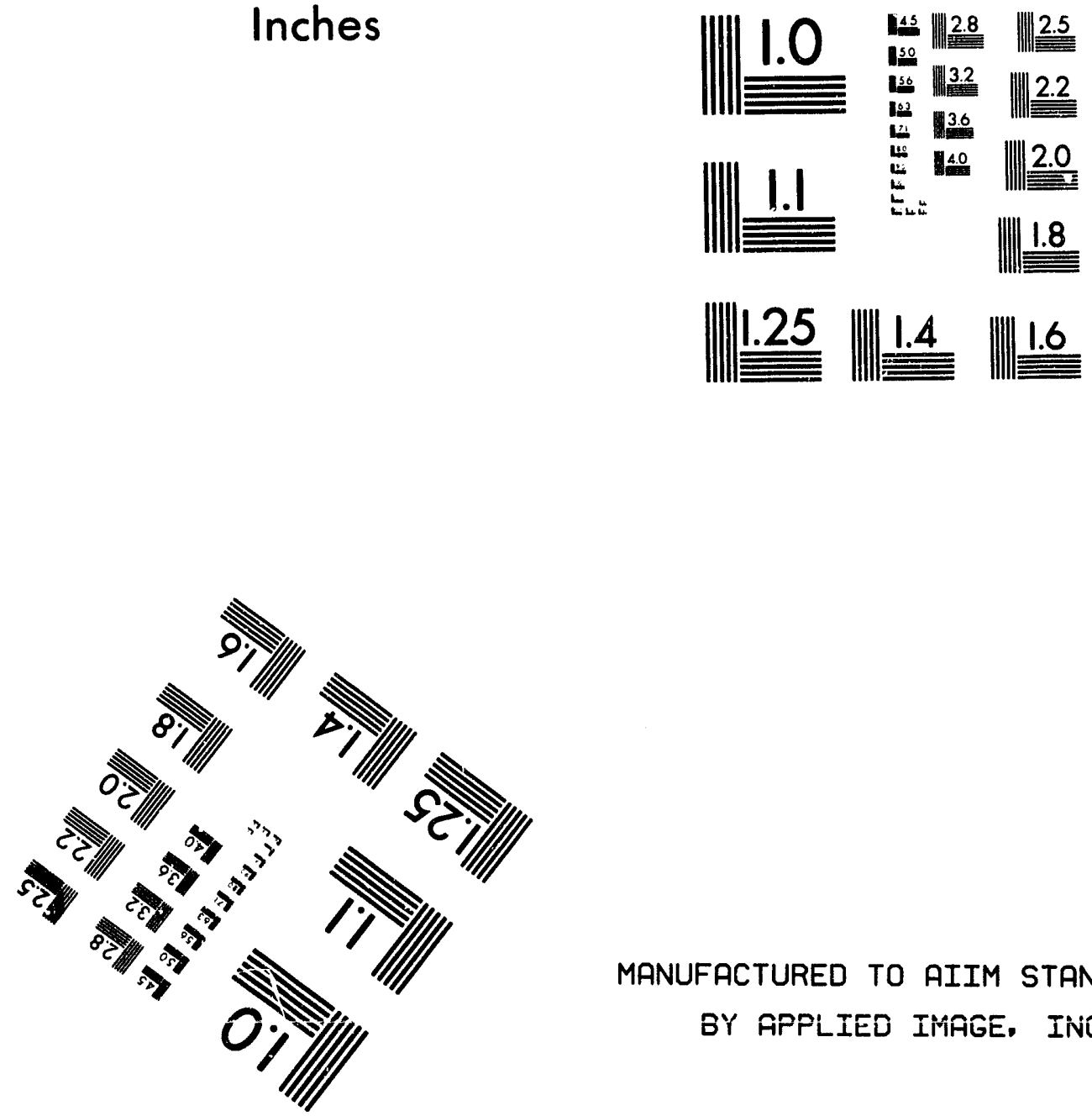

MANUFACTURED TO AIIM STANDARDS

BY APPLIEO IMAGGE, INC.

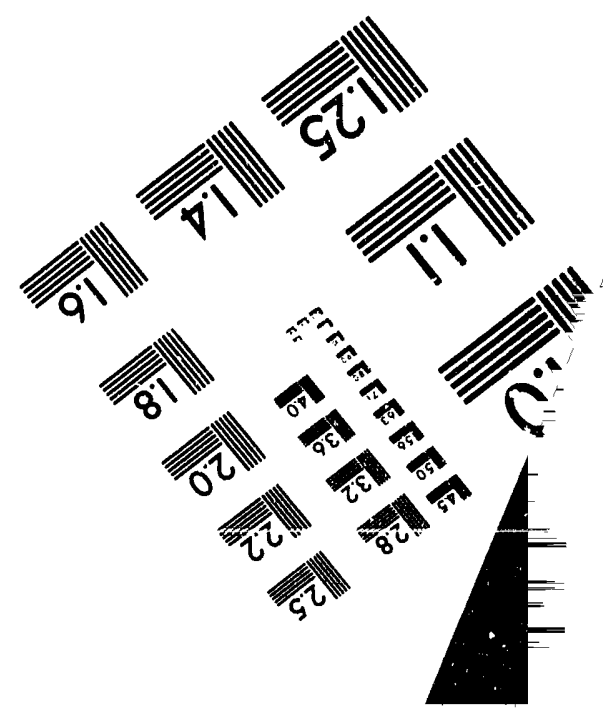



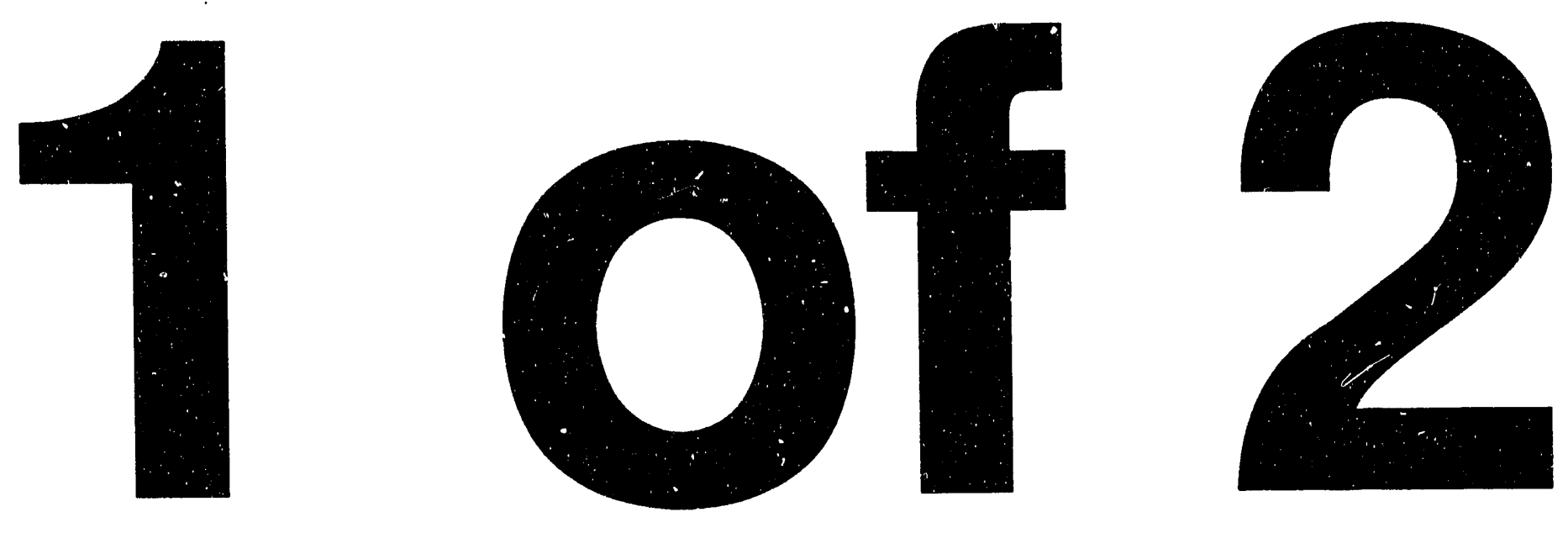


\section{Tank Farm Surveillance and Waste Status Summary Report for April 1993}

B. M. Hanlon

Date Published

July 1993

Prepared for the U.S. Department of Energy Office of Environmental Restoration and Waste Management

\footnotetext{
(2) Westinghouse Hanford Company Richland, Washington 99352

Hanford Operations and Engineering Contractor for the

U.S. Department of Energy under Contract DE-AC06-87FL10930
} 
WHC-EP-0182-61

APPROVAL

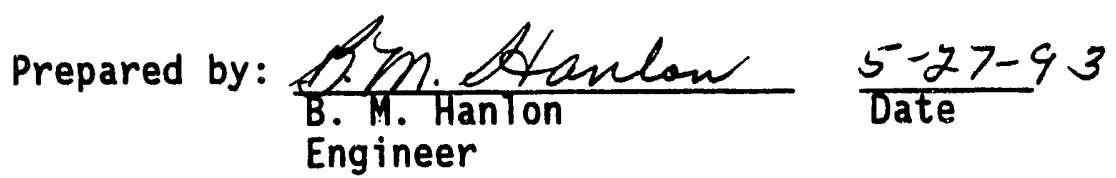

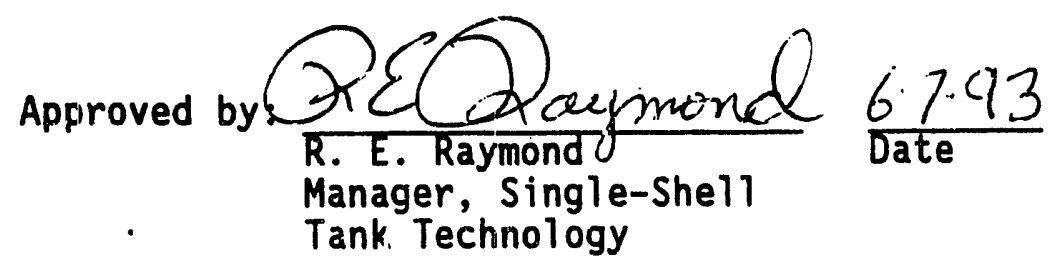

i i 


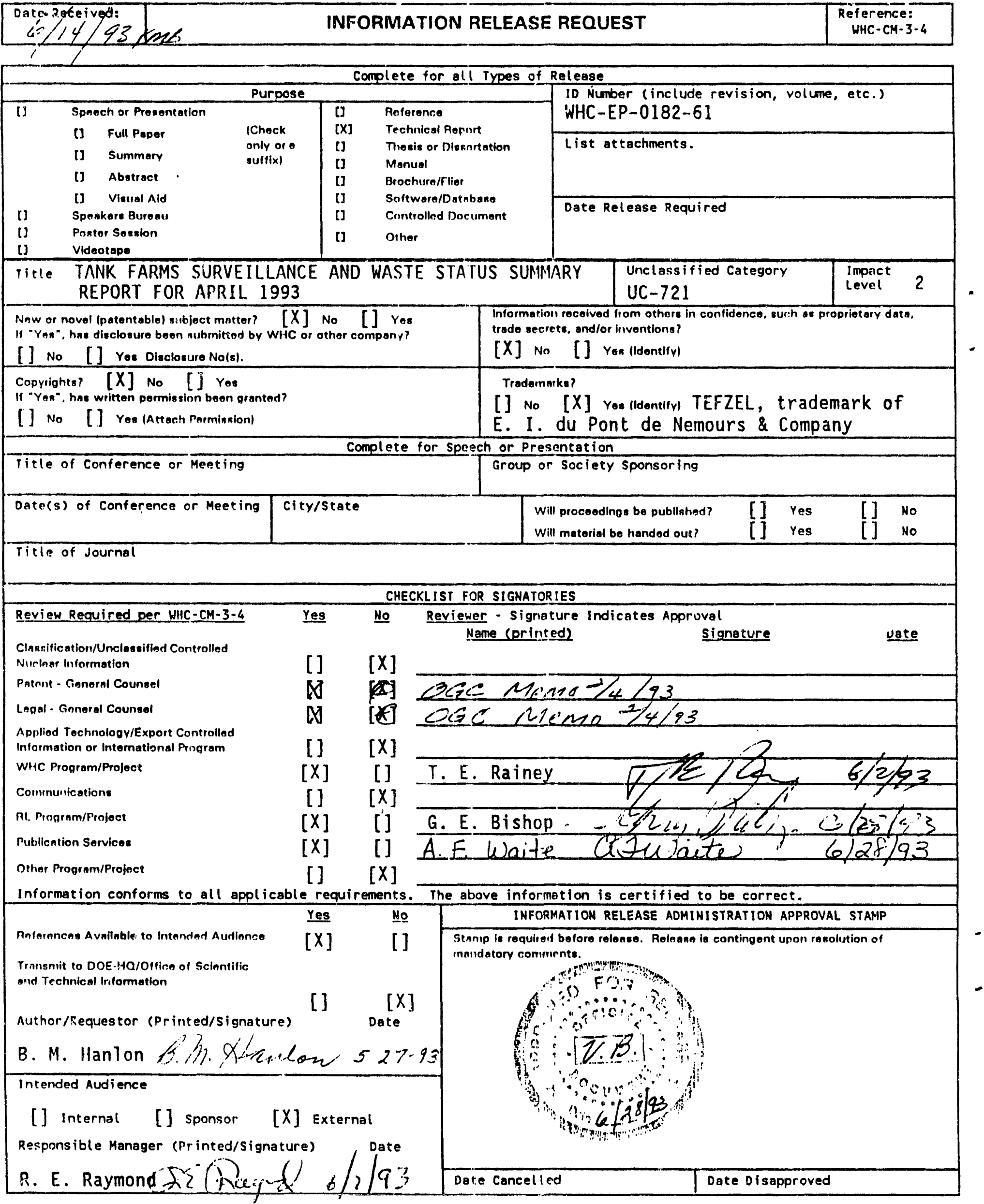


WHC-EP-0182-61

TANK FARM SURVEILLANCE AND WASTE STATUS

SUMMARY REPORT FOR APRIL 1993

B. M. Hanlon

ABSTRACT

This report is the official inventory for radioactive waste stored in underground tanks in the 200 Areas at the Hanford Site. Data that depict the status of stored radioactive waste and tank vessel integrity are contained within the report. This report provides data on each of the existing 177 large underground waste storage tanks and 49 smaller catch tanks and special surveillance facilities, and supplemental information regarding tank surveillance anomalies and ongoing investigations. This report is intended to meet the requirement of $U$. S. Department of Energy-Richland Operations Office Order 5820.2A, Chapter I, Section 3.e. (3) (DOE-RL, 1990, Radioactive Waste Management, U. S. Department of Energy-Richland Operation Office, Richland, Washington) requiring the reporting of waste inventories and space utilization for Hanford Tank Farm Tanks. 
WHC-EP-0182-61

This page intentionally left blank. 


\section{CONTENTS}

SUMMARY

TANK STATUS

TANK INVESTIGATIONS

HIGHLIGHTS

Appendixes:

A. TANK AND EQUIPMENT CODE AND STATUS DEFINITIONS . . . . . . . . . . . . . A A-1

Tank and Equipment Code/Status Definitions . . . . . . . . . . . . A-3

B. TANK FARM CONFIGURATION, STATUS AND FACILITY CHARTS . . . . . . . . . . B-1

1 High-Level Waste Tank Configuration . . . . . . . . . . . . . . B-3

$\therefore$ Double-Shell Tank Instrumentation Configuration . . . . . . . . B-4

3 Single-Shell Tank Instrumentation Configuration . . . . . . . . B-5

4 Double-Shell Tank Status . . . . . . . . . . . . . . B-6

5200 E Single-She 11 Tank Status... . . . . . . . . . . . . . B-7

6200 W Single-Shell Tank Status . . . . . . . . . . . . . . . . . . B-9

7 Tank Farm Facilities Quick Reference . . . . . . . . . . . . . B-11

8 Hanford Tank Farms Facilities Chart . . . . . . . . . . . . B-12

C. MONTHLY SUMMARY . . . . . . . . . . . . . . . . . . . . . C-1

1 Monthly Summary . . . . . . . . . . . . . . . . . . . . C-3

2 Tank Use Summary . . . . . . . . . . . . . . . . . . . . . C-4

3 Inventory Summary by Tank Farm . . . . . . . . . . . . . . . . C-5

4 Inventory and Status by Tank - Doubie-Sheil Tanks . . . . . . . . C-6

5 Inventory and Siatus by Tank - Single-Shell Tanks . . . . . . . . C-9

D. PERFORMANCE SUMMARY . . . . . . . . . . . . . . . . . . . . . D-1

1 Performance Summary . . . . . . . . . . . . . . . . D-3

E. LIQUId STATUS ANC PUMPABLE LiQUid REMAINING IN TANKS . . . . . . . . . E-1

1 Liquid Status and Pumpabie Liquid Remaining in Tanks . . . . . . . E-3

F. PUMPING RECORD ............................ . . F-1

1 Pumping Record . . . . . . . . . . . . . . . . . . . F-3

G. CATCH TANKS AND SPECIAL SURVEILLANCE FACILITIES . . . . . . . . . . . . G-1

1 East and West Area Catch Tanks and Special

2 East Area Catch Tanks and Special Surveillance

3 West Area Catch Tanks and Special Surveillance
Facilities (Inactive) . . . . . . . . . . . . . G-5

H. LEAK VOlUME ESTIMATES . . . . . . . . . . . . . . . . . . . . H-1

1 Single-Shell Tank Leak Volume Estimates . . . . . . . . . . . . . H-3 
WHC-EP-0182-61

This page intentionally left blank. 


\section{LIST OF TABLES}

1 Watch List Tanks .................... . . 7

2 Tanks Containing $>1,000$ gram mole of Ferrocyanide (Watch List Tanks) . . . . . . . . . . . . . 8

3 Tanks with Potential for Hydrogen or Flammable Gas Accumulation Above the Flammability Limit (Watch List Tanks) . . . . . . . 10

4 Tanks Containing Concentritions of Organic Salts $>3 \%$ Weight TOC (Watch List Tanks) . . . . . . . . . 11

5 Single-She11 Tanks with High Heat Loads $(>40,000 \mathrm{Btu} / \mathrm{hr})$. . . . . . 12

6 Double-Shell Tank Waste Type and Space Allocation . . . . . . . . 14

7 Automatic Food Instrument Company (FIC) Gauges Out of Service . . . 15

8 Single-Shell Tanks Monitoring Compliance Status . . . . . . . 16

9 Double-Shell Tanks Monitoring Compliance Status ......... 21

\begin{tabular}{|c|c|c|}
\hline \multicolumn{3}{|c|}{ METRIC CONVERSION CHART } \\
\hline 1 inch & $=$ & 2.54 centimeters \\
\hline 1 foot & $=$ & 30.48 centimeters \\
\hline $1 \mathrm{gallion}$ & $=$ & 3.80 liters \\
\hline 1 ton & $=$ & 0.90 metric tons \\
\hline \multicolumn{3}{|c|}{${ }^{\circ} \mathrm{F}=\left(\frac{9}{5}{ }^{\circ} \mathrm{C}\right)+32$} \\
\hline \multicolumn{3}{|c|}{$\begin{array}{c}1 \mathrm{Btu} / \mathrm{h}=2.93071 \mathrm{l} \text { E-01 watts } \\
\text { (International Table) }\end{array}$} \\
\hline
\end{tabular}


WHC-EP-0182-61

This page intentionally left blank

X 
WHC-EP-0182-61

\section{TANK FARM SURVEILLANCE AND WASTE STATUS SUMMARY REPORT FOR APRIL 1993 \\ SUMMARY}

Note: Changes from the previous month are in bold print.

TANK STATUS

\begin{tabular}{|c|c|c|}
\hline Category & Quantity & Date of Last Change \\
\hline In-Service Tanks ${ }^{c}$ & 28 double-shall & $10 / 86$ \\
\hline Out-of-Service Tanks & 149 single-shell & $07 / 88$ \\
\hline Assumed Leaker Tariks ${ }^{f}$ & 67 single-shell & $10 / 92$ \\
\hline Sound Tanks & $\begin{array}{l}28 \text { double-shell } \\
82 \text { single-sheil }\end{array}$ & $\begin{array}{c}1986 \\
10 / 92 \\
\end{array}$ \\
\hline Interim Stabilized Tanks ${ }^{b, d}$ & 106 single-shel? & $04 / 93$ \\
\hline Not Interim Stabilized ${ }^{f}$ & 43 single-shell & $04 / 93$ \\
\hline Interim Isolated Tanks & 98 single-she 11 & $09 / 91$ \\
\hline Watch List Tanks & $\begin{array}{r}48 \text { single-she } 11 \\
6 \text { double-she } 11\end{array}$ & $\begin{array}{c}1991 \\
11 / 92 \\
\end{array}$ \\
\hline
\end{tabular}

Although all 149 single-shell tanks were removed from service (i.e., no longer authorized to receive waste) as of November 21, 1980, the category of "Out-of-Service" was not established until July 1988.

b of the 105 tanks classified as interim stabilized, 58 are listed as assumed leakers. The total of 105 interim stabilized tanks includes eight tanks that do not meet current established supernatant and interstitial liquid stabilization criteria: 104-B, 107-B, 110-B, 111-B, 110-BX, 102-T, 112-T, and 110-U. (These tanks did meet the criteria in existence when they were declared interim stabilized.)

c six double-shell tanks listed as "in service" are currently included on the Hydrogen Watch List and are thus prohibited from receiving waste in accordance with "Safety Measures for Waste Tanks at Kanford Nuclear Reservation," Section 3137 of the National Defense Authorization Act for Fiscal Year 1991, November 5, 1990, Public Law 101-510.

d of the 48 single-shell tanks on Watch Lists, 22 have beon Interim Stabilized.

ef the 48 single-shell tanks on Watch Lists, 20 have been Interim Isolated. details.

${ }^{\dagger}$ Nine of the tanks are both assumed leakers and not Interim Stabilized, See Appendix $H$ for more

\section{TANK INVESTIGATIONS}

This section includes all single-shell tanks or catch tanks on the Alert List for surface level or interstitial liquid level (ILL) decreases, or for drywell/lateral radiation level increases.

Tank 241-SX-102. On Apri1 30, 1993, the quarterly Liquid Observation Well (LOW) reading taken in Tank 241-SX-102 indicated a decrease of 0.2 feet from the established baseline. Previous neutron LOW readings have been stable showing minor fluctuation between the baseline and 0.2-foot decrease. Instrument repeatability is \pm 0.1 foot. The LOW is the primary means of liquid level detection because this tank has a solid surface. 
A. Assumed Leakers or Assumed Re-leakers: (See Appendix A for definition of "Re-leaker")

This section includes all single- or double-shell tanks or catch tanks for which an off-normal or unusual occurrence report has been issued for assumed leaks or re-leaks. Tanks/catch tanks will remain on this 1 ist until either a) completion of Interim Stabilization, or b) the updated occurrence report indicates that the tank/catch tank is not an assumed leaker.

Tank 241-BX-111. The surface level has shown an erratic increase since 1986. Previous readings were 80.00 inches. A decreasing trend was observed during February 1993, but has since remained stable, fluctuating between 78.75 and 79.00 inches during March and Apri1 1993. This tank has a 1.00-inch decrease criteria from a baseline of 80.00 inches. The liquid observation well (LOW) interstitial liquid level (ILL) is stable as of April 1, 1993. Resolution status: This tank was official?y declared an assumed re-leaker on April 30; however, notifications were made to regulatory agencies on March 24, and again on April 6, 199. Preparations to begin emergency pumping have begun. Upon completion of pumping, the tank will be rebaselined. See Item 4 . Occurrence Report RL-WHC-TFARM-1993-0035 for further in iormation.

\section{B. Tanks with increases indicating possible intrusions:}

This section includes all single-shell tanks for which the surveillance data shows that the surface level or ILL has met or exceeded the increase criteria (this section does not include all tanks on the Alert List because the criteria for the Alert List is $50 \%$ of the increase criteria).

Tank 241-B-202. A steady increase in the surface level measurement has been observed since December 1984. The manual tape pencil plummet is contacting liquid. When the quarterly reading was obtained on October 6 , 1992, the level was recorded as 144.75 inches, thus exceeding the 2.00-inch increase criteria from the established baseline of 142.50 inches The surface level measurement was rechecked on October 9, 1992, (145.50 inches) and October 13 (145.00 inches), verifying the increase and that the criteria had been exceeded. The monitoring frequency has been increased from quarterly to monthly. Occurrence Report RL-WHC-TANKFARM-1993-0024 was issued February 13, 1993. An engineering evaluation of this tank will begin as soon as all evaluations for tank level decreases are complete. Resolution status: A photo package will be initiated to investigate the possibility of an intrusion. Review of previous photos was inconclusive. The tank was administratively stabilized in May 1985. Photos are required to determine the actual supernatant increase, if any. In the interim, a temporary baseline will be established at 145.00 inches.

Tank 241-BX-103. On January 18, 1993, the surface level measurement in 103-BX exceeded the 0.50-inch increase criteria from the reference baseline of 19.50 inches, and was verified on January 20, 1993. The surface level measurement is currently at 20.40 inches. This tank has shown an erratic increase in surface level measurements since January 6, 1986. Discrepancy Report S\&DA 93522 was issued January 21, 1993. Occurrence Report RL-WHC-TANKFARM-1993-0036 was issued March 25, 1993. The FIC plummet is contacting liquid as indicated by in-tank photographs taken October 31, 1986. Tank 241-BX-103 is Sound, and Interim Stabilized/Interim Isolated. Resolution status: The current level is greater than that prior to stabilization in November 1983. The tank was previously determined to have experienced an intrusion from 1977 to March 1983 
(prior to stabilization). Subsequent isolation was expected to halt the intrusion, but apparentiy this has not happened. Work packages will be initiated to re-seal pits and risers and obtain in-tank photos. The photos will be used to assess the current stabilization status of the tank. A visual survey of the area will also be performed to determine possible paths for precipitation to enter the tank.

Tank 241-TX-113. The LOW ILL has shown a slow increase since March 12, 1986, with both the neutron and gamma probes. This tank appeared on the Alert List in 1989, when the ILL reached $50 \%$ of the $0.4-$ foot increase criteria, but was removed in 1990 when the ILL appeared stable for longer than a 12-month period. The scan data on February 5, 1993, shows the ILL to be 5.5 foot and at the 0.4-foot increase criteria from the reference baseline. S\&DA Discrepancy Report 93-534 was issued March 10, 1993. Resolution status: The technical evaluation of this tank was completed April 14, 1993. The results are inconclusive, with recommendation to accelerate the october 1997 waste characterization of the tank. This characterization is expected to confirm that solids are dissolving, causing an increase in ILL. It is also recommended that new photos be taken of the tank interior. The photo packages will be initiated in June 1993, and a letter will be written in July to request acceleration of waste characterization. LOW scans and surface level readings will be increased from a quarterly to a monthly frequency.

Tank 241-TX-115. The LOW ILL is exceeding the 0.4 -foot increase criteria from the reference baseline. This tank has been on report since 1988, when the increase criteria was first exceeded. Comparison of past and present in-tank photographs show no significant change in surface conditions or obvious evidence of intrusion. Surveillance Deviation Report \#88-08 was issued on May 18, 1988, and Event Fact Sheet \#TF-EFS-88-140 was issued October 27, 1988. This tank appeared on the Executive Summary Report and Alert List until December 31, 1991, when this report was discontinued. The scan data for February 5, 1993, showed an additionai increase of 0.1 feet in the ILL since the previous scan data from October 23, 1992. The ILL continues to show an increase with both the neutron and gamma probes. Resolution status: The technical evaluation of the alert condition in this tank was completed April 14, 1993. The results were inconclusive, with recommendation to accelerate the october 1997 waste characterization. Waste characterization is expected to confirm that solids are dissolving, causing an increase in ILL. The 1981 photos show evidence of rain intrusion through a central pump pit riser. However, it cannot be concluded from the 1988 photos that the intrusion is ongoing. A photo package will be initiated. This tank will be included in the waste characterization with 113-TX. LOW scans and surface level readings will be increased from a quarterly to a monthly frequency.

Tank 241-TY-102. On November 8, 1992, the automatic FIC surface leve1 measurement of 32.10 inches exceeded the 0.50 -inch increase criteria from the rejerence baseline of 31.40 inches. Discrepancy Report S\&DA-92-489 was issued November 9, 1992. The tank has a history of icicle buildup on the FIC plummet and intrusions. The surface level measurement was 31.90 inches as of April 1 , 1993 and at increase criteria. Resolution status: This tank is experiencing an ongoing intrusion as is evident by comparison of November 1984 photos with July 1987 photos and an increasing trend in surface level data. Work packages will be initiated to re-seal pits and risers and obtain in-tank photos. The new photos will be used to assess the current stabilization status of the tank. A visual survey of the area wi!l a!so be performed by the same date to determine possible paths for precipitation to enter the tank. 
Vent Station Catch Tank. The zip cord surface level reading exceeds the maximum operating limit of 36.00 inches. The manual tape has been out of service since Juiy 7, 1992. A temporary zip cord was installed December 16, 1992. The level was 45.50 inches which exceeded the active tank 1 imit of $50 \%$ volume of 40 inches ( 400 gallons). Transfers are not permitted until the tank is pumped and the level is within limits. Discrepancy Report S\&DA-92-511 was issued December 24, 1992. Resolution status: Work packages are out to repair the manual tape and pump the catch tank. Extensive surface contamination in the surrounding area is hampering efforts to perform the needed activities. Sampling of the solution in the tank is necessary before pumping can begin. Estimated date of completion of pumping is June 30, 1993.

UX-302-A Catch Tank. Surface level measurement, exceeds the maximum operating limit of 50.00 inches. The level is 62.60 inches which exceeds the $50 \%$ volume of 54 inches (8840 gallons). The FIC plumriet is contacting liquid.

Discrepancy report S\&DA-92-465 was issued May 12, 1992. A work package was initiated to pressure test lines and to pump liquid level to below alarm limits. Resolution status: Work packages for the transfer of waste from UX302-A and the repair of necessary instrumentation are being prepared, and the transfer of waste is being scheduled as a prestart item for the Cross site Transfer.

C. The following tanks have been reported as assumed leakers, and al though shown as Interim Stabilized, they do not meet current Interim Stabilization criteria. Surveillance data do not show an indication of a continuing leak.

$\begin{array}{ll}104-B & 110-B X \\ 107-B & 102-T \\ 110-B & 112-T \\ 111-B & 110-U\end{array}$

II. HIGHLIGHTS

1. Criticality Safety Issues

On April 30, 1992, an Unreviewed Safety Question (USQ) concerning criticality safety issues in the Tank Farms was declared to be a reportable event. Unusual Occurrence report RL-WHC-TANKFARM-1992-0037 was issued. A prohibition was placed on all waste transfers into and between the tank farm facilities which is negatively affecting various Hanford programs. On September 1, 1992, the approved Justification For Continued Operations (JCO) was received. This establishes the limitations for all tanks receiving transfers and also excludes any interim stabilization of single-shell tanks until further evaluations are completed and approved by $\mathrm{DOE}-\mathrm{HQ}$. On December 15, 1992, the approved JCO was issued as WHC-SD-WM-JCO-001, "Justification for Continued Operations of Hanford High Level Waste Tanks Resulting From the Criticality USQ, 492-CRITSAS." An amendment request to this JCO to pump and stabilize Tank 241-T-101 has been approved by DOE-HQ. Interim stabilizion of Tank 101-T was completed on April 14, 1993; official Interim Stabilization notification to regulating agencies will follow. See \#2 below and Table C.5 (Inventory and Status by Tank) for further information. Resolution of the USQ is scheduled for summer 1993. 


\section{Interim Stabilization of Tank 241-T-101}

Tank 101-T was declared an assumed 1eaker on October 4, 1992. Total leakage is assumed to be approximately 7500 gallons. Approval from DOE-HQ to pump the tank was received on February 25, 1993. On March 8, a saltwell screen and saltwell pump were installed and pumping began on March 12, 1993. The commencement date deadline of March 15 as required by the Hanford Federal Facility Agreement and Consent Order (Tri-Party Agreement) milestone M-05-16 for pumping 101-T was therefore met. Shutdown of pumping activities occurred on March 13, after the doubie-container receiving tank (DCRT 244-TX) had reached maximum liquid level for this transfer. 18,203 gallons were transferred from 101-T to 244-TX. Sampling of the contents of 244-TX was completed, and then transferred to double-shell tank 102-SY. Pumping from 101-T to 244-TX was resumed on March 26, 1993. Transfer was stopped because of low suction from no liquids being drawn through the pump. The system was flushed out and pumping was completed on April 6, 1993. Total gallons pumped was 25,300. In-tank photographs were taken Apri1 7, 1993, and show a pockinarked, moist sludge surface, surface-cracked near the outer perimeter of the tank. Approximately 3 feet of saltwell screen is visible below the waste remaining in the center of the tank. The FIC plummet is visible and contacting solids. A liquid pool surrounds the saltwell screen. From the intank photographs, the quantity of remaining supernatant in the tank was estimated as 700 gallons, with 15,800 gallons of drainable interstitial liquid and 16,500 gallons drainable liquid remaining. The evaluation for meeting interim stabilization criteria was completed on April 14, 1993; official Interim Stabilization notification to regulating agencies will follow. See Table C-5, Status and Inventory by Tank, for further information.

\section{Installation of Thermocouple Trees}

Installation of one new thermocouple tree each in Tanks 241-BY-111 and BY-112 was completed on March 31, 1993, meeting the DOE-RL Performance Indicator milestone. Each thermocouple tree has six thermocouples. The two new trees are to be connected to the Tank Monitoring and Control system (TMACS), the automatic monitoring system. The trees are currently manualiy monitored which will continue until the connection is accomplished.

\section{Occurrence Reports}

RL-WHC-TFARM-1993-0035 (UNUSUAL) - TANK 241-BX-111 SURFACE LEVEL DECREASE AND CHANGE FROM STEADY STATE CONDITION (10-Day Update Apri1 6, 1993)

Tank 241-BX-111 is exhibiting a fluctuating surface level. Manual tape (MT) liquid level measurements taken during 1993 indicate a liquid level decrease which is a change from the previous trend. The tank has historically shown a slowly increasing level trend (.5 inches over the previous seven years). However, the trend has clearly reversed according to the recently obtained MT surface level data. The reading frequency has been. increased to daily. The latest in-tank photos (taken in 1985) show floating solids on the surface. Those photos al:0 show the MT plummet with a coating of crystallized waste. Either condition could interfere with the ability to obtain accurate MT surface level readings. Each inch of liquid level represents 2750 gallons. Other surveiliance data taken for this tank have been reviewed and no other changes have been noted. Leak detection drywells are stable. 
The tank was declared an "assumed leaker" in 1984 and pumped in 1985. The tank is estimated to still contain approximately 50,000 gallons of drainable interstitial 1iquid. Approximately 46,000 gallons of liquid could be removed using a saltwell (jet) pump, so the tank is not considered to be interim stabilized, and is partially interim isolated. This tank was scheduled to be saltwell pumped in 1990. However, the saltwell pumping plans were canceled on August 31, 1990, when the tank was added to the ferrocyanide ( $\mathrm{FeCN}$ ) Watch List. The presence of FeCN in the waste has been declared an Unreviewed Safety Question (USQ).

On March 31, 1993, calculations were completed to determine if reportable quantities of hazardous materia's were potentially released (if it is determined that the tank did actually leak). On April 1, the calculations were reviewed by management and it was determined that amounts exceeding the reportable quantity for $C_{5}-137, U-238$, and sodium may have been released. After discussions with WHC and DOE-RL personnel, it was determined to notify the appropriate regulatory agencies that reportable quantities may have been released to the environment. This Occurrence Report was upgraded to an Unusual Occurrence on April 1, 1993.

The surface level decrease is still under evaluation. Initial corrective actions include vapor studies, manual tape maintenance, and a new series of in-tank photos. The new photos, when compared with those taken in 1985, will reveal any changes in the condition of the tank contents. Based on the experience gained with Tank 241-T-101, it is expected to take several months to obtain permission to take in-tank photos. Preparations for emergency pumping have been initiated, with August 1993 as the estimated date to start pumping because of the USQ nature of the waste. 

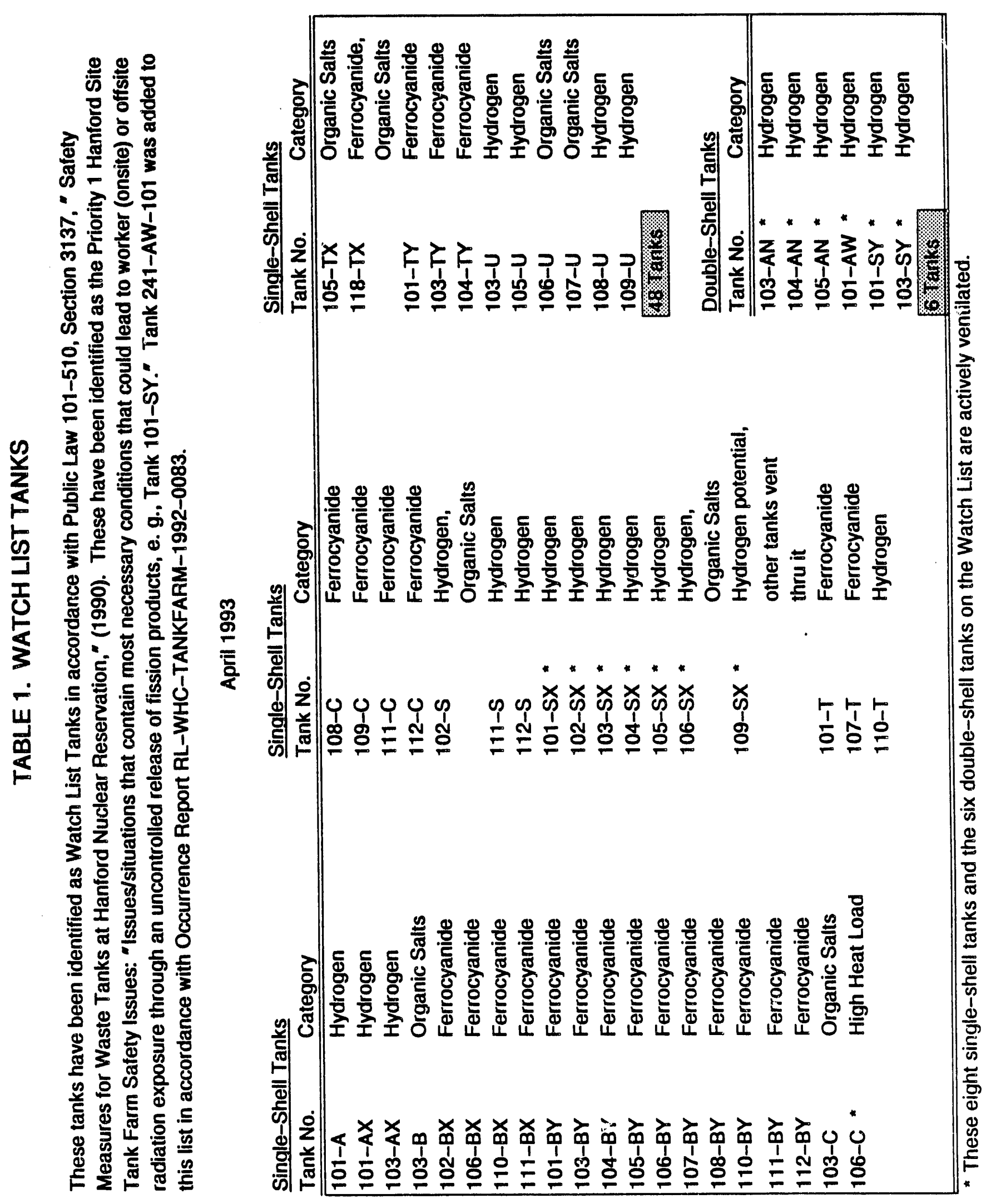

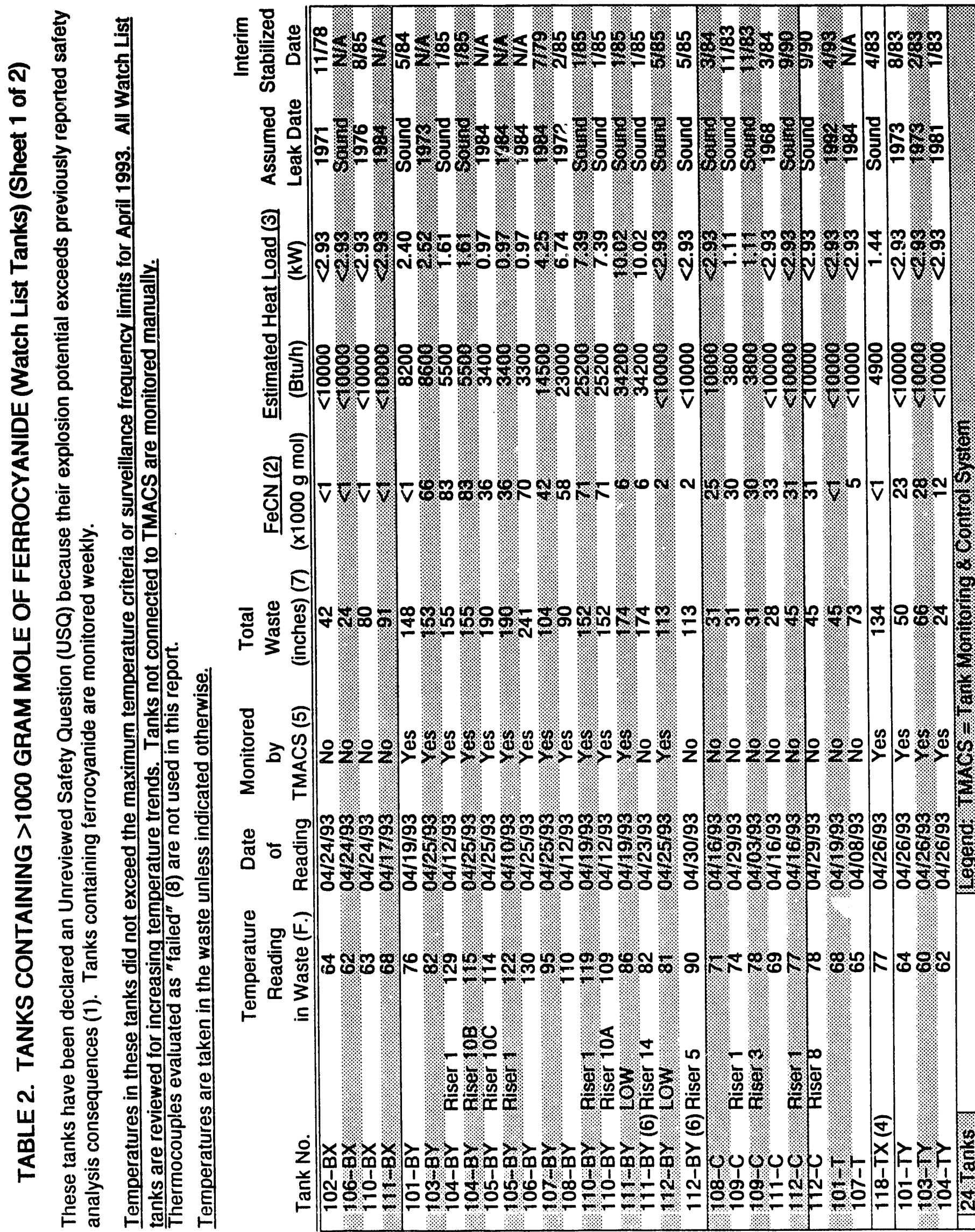

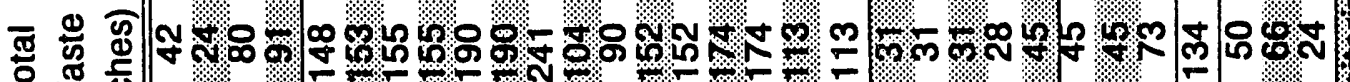

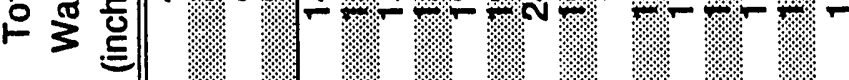

总

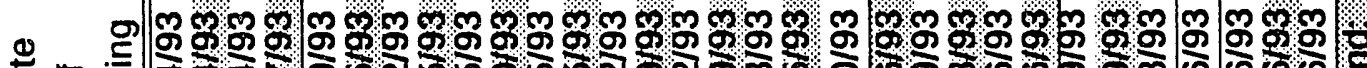

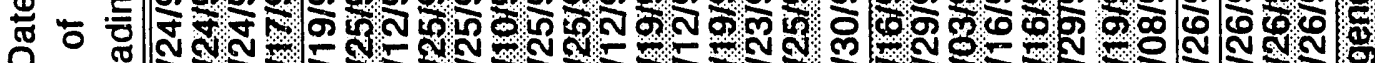

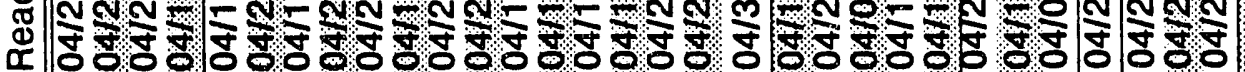
凹

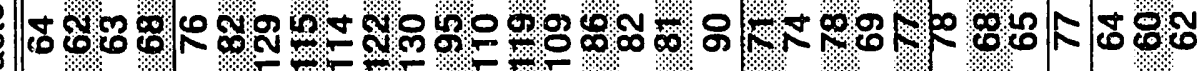
.

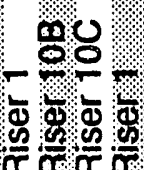

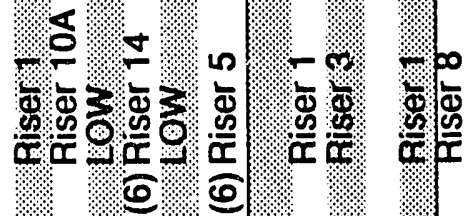

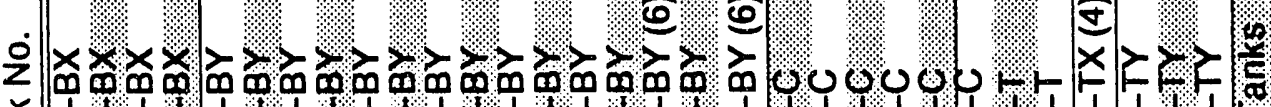

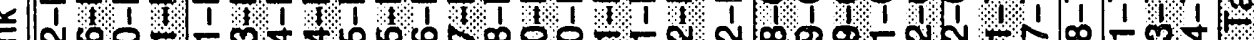

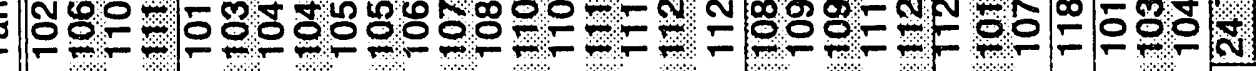



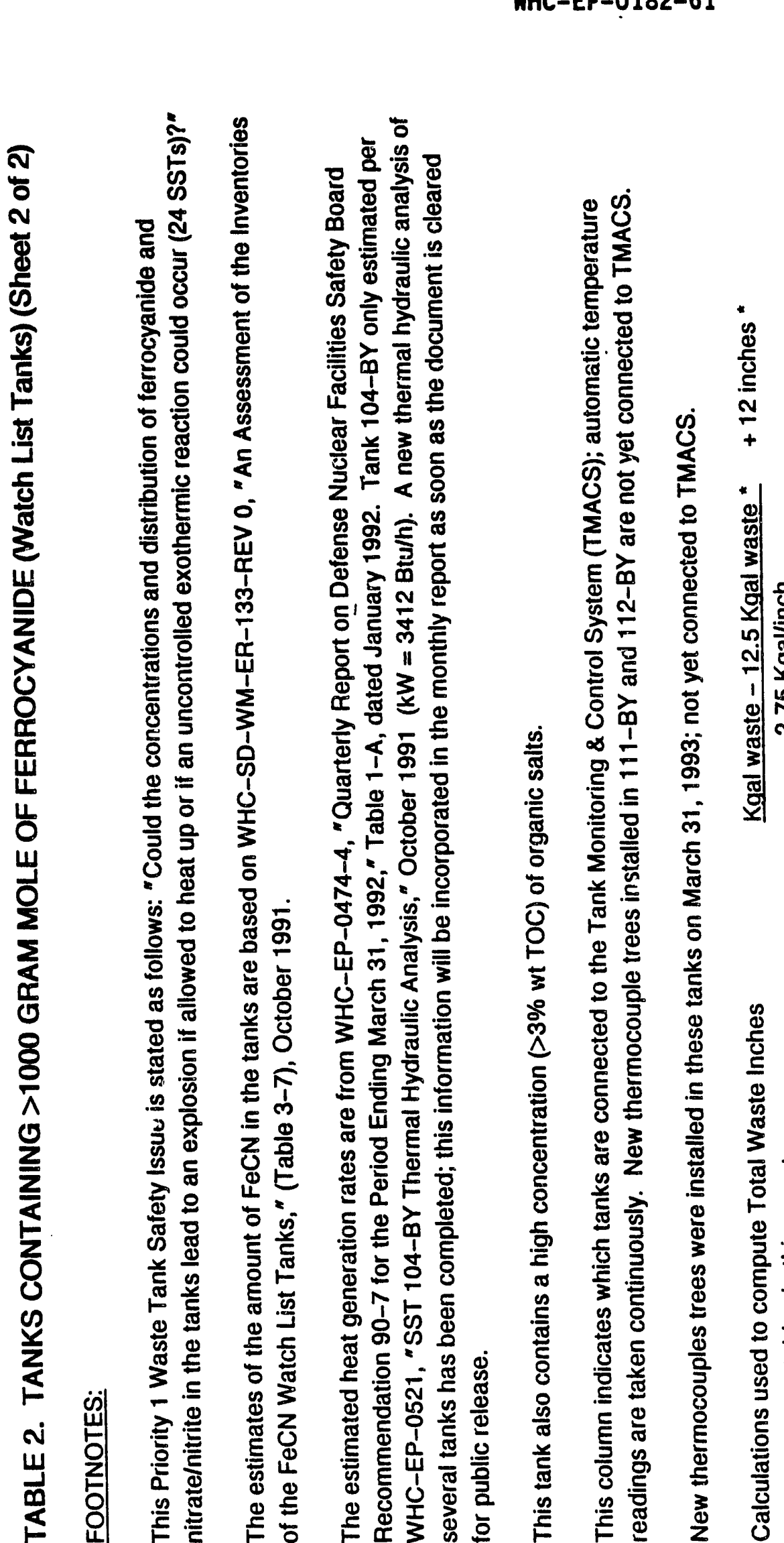


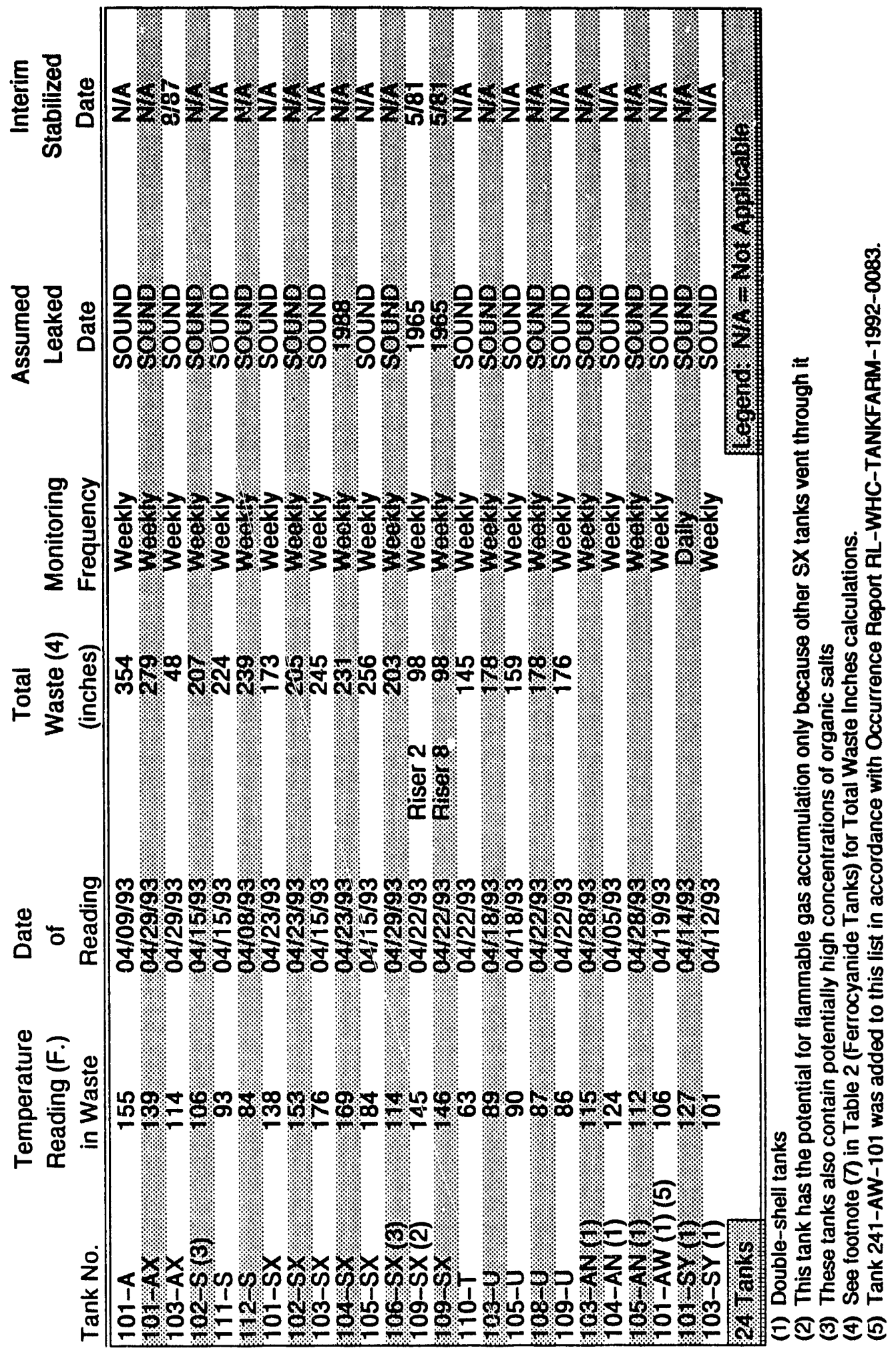



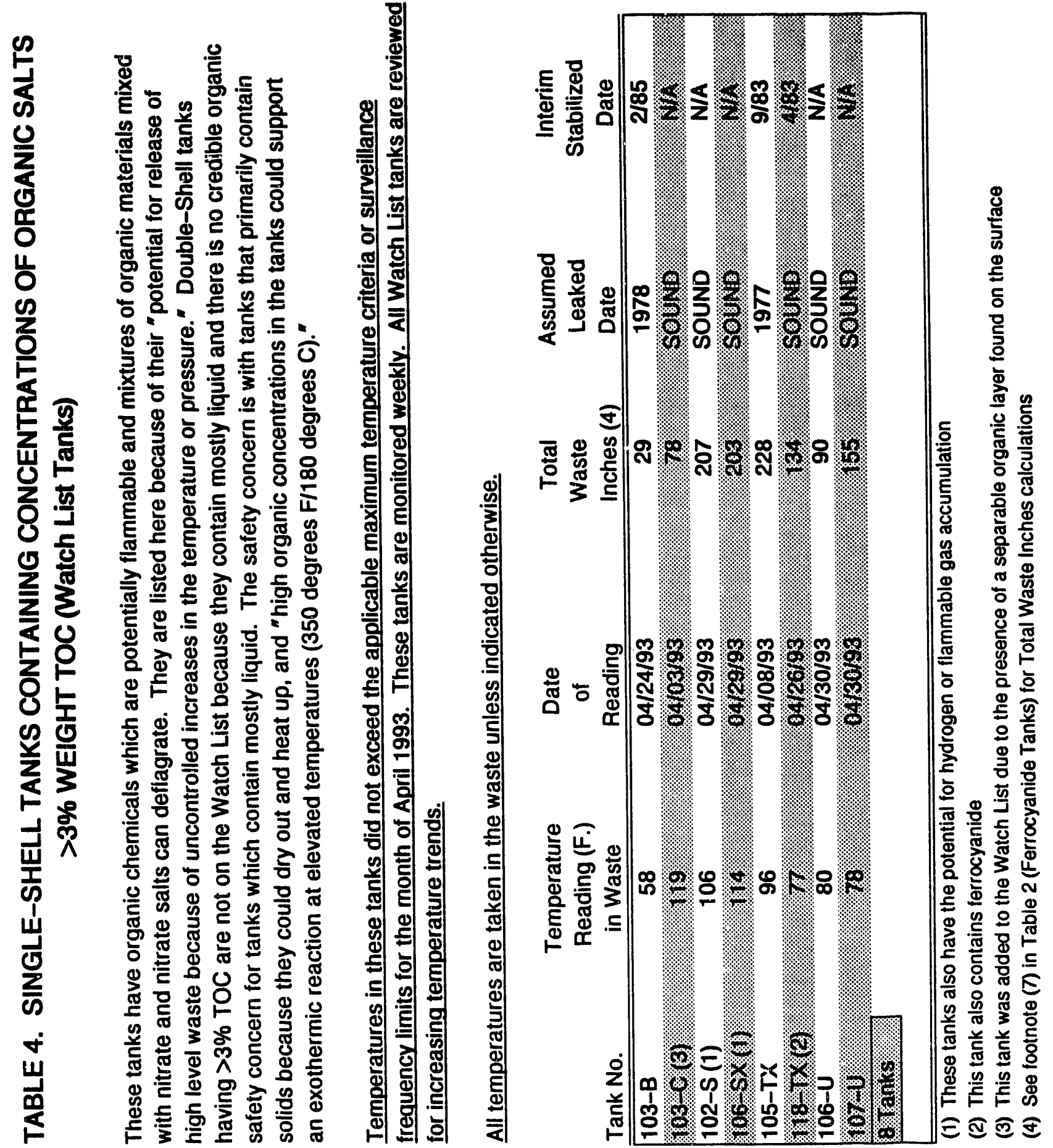


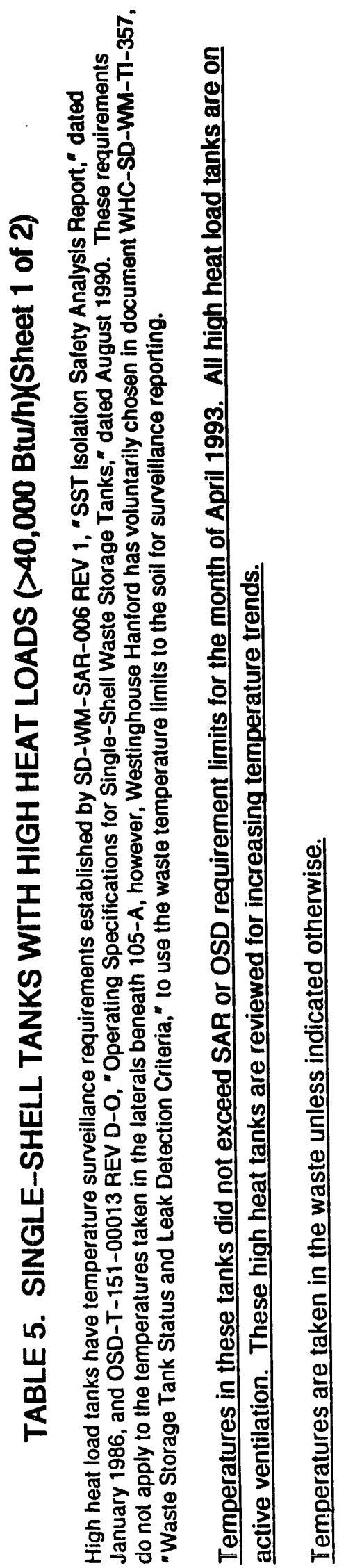

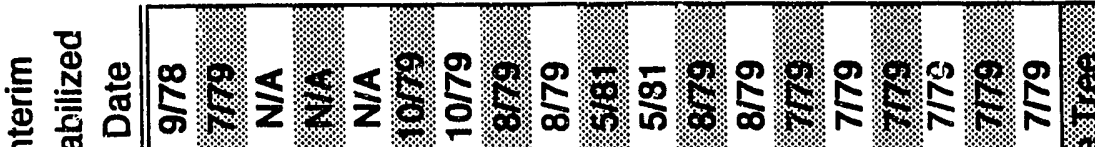

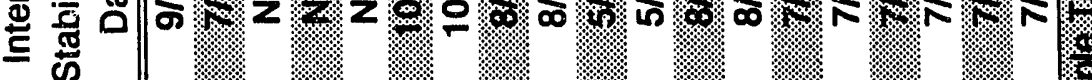

Ф

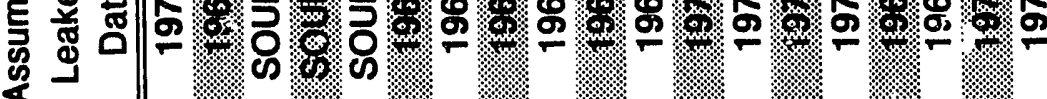

$\exists \quad$ ๑ 马

이

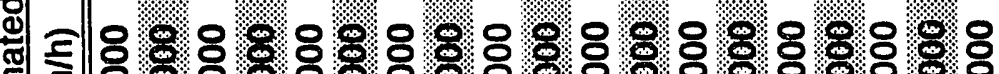
氙 畐

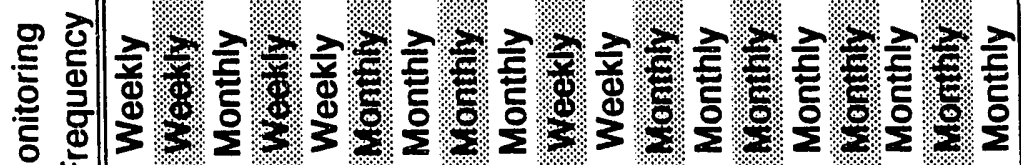

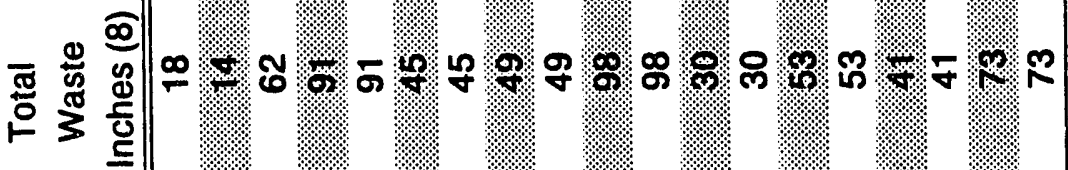

동

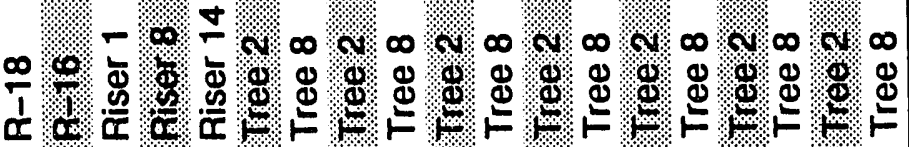

이요 \% \% \%

8.8

売 18

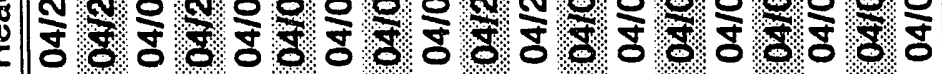

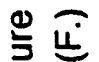

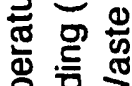

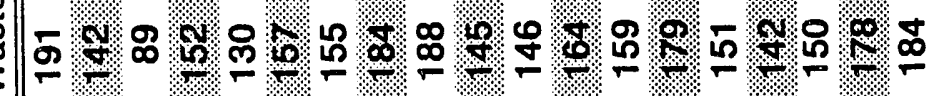
동 드

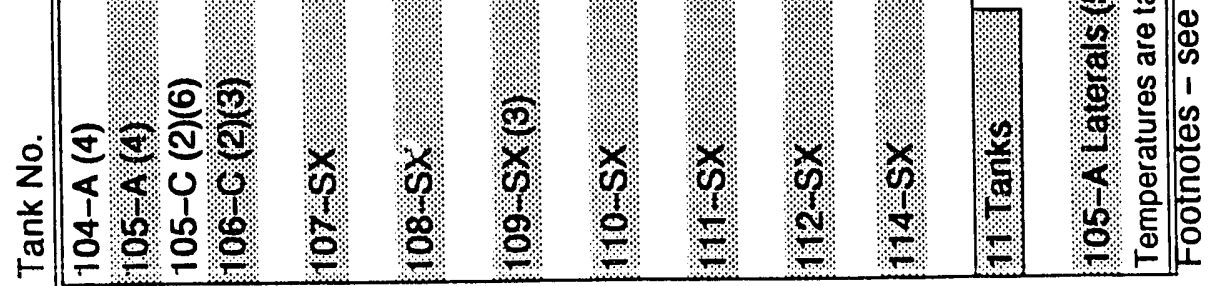


WHC-EP-0182-61

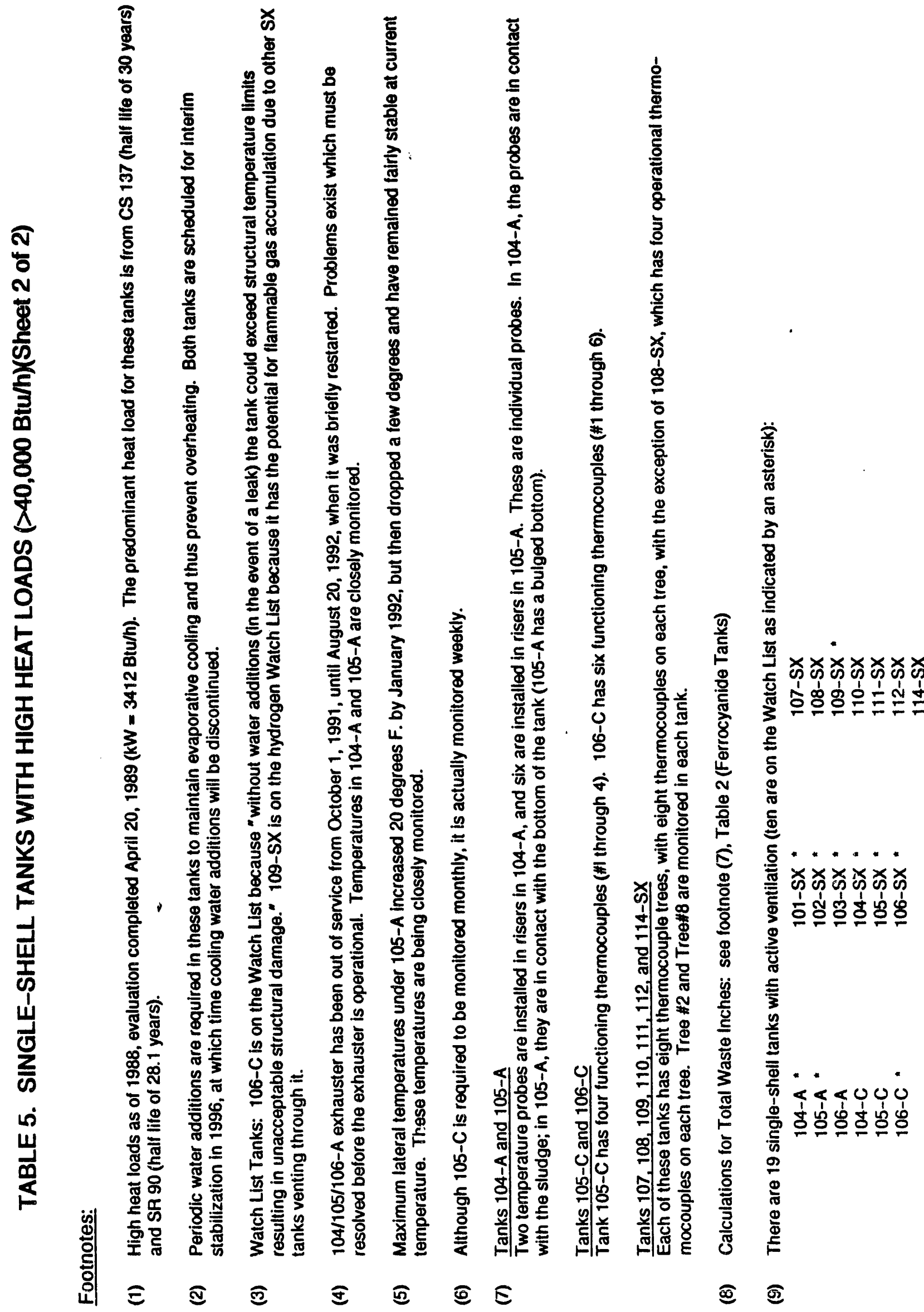




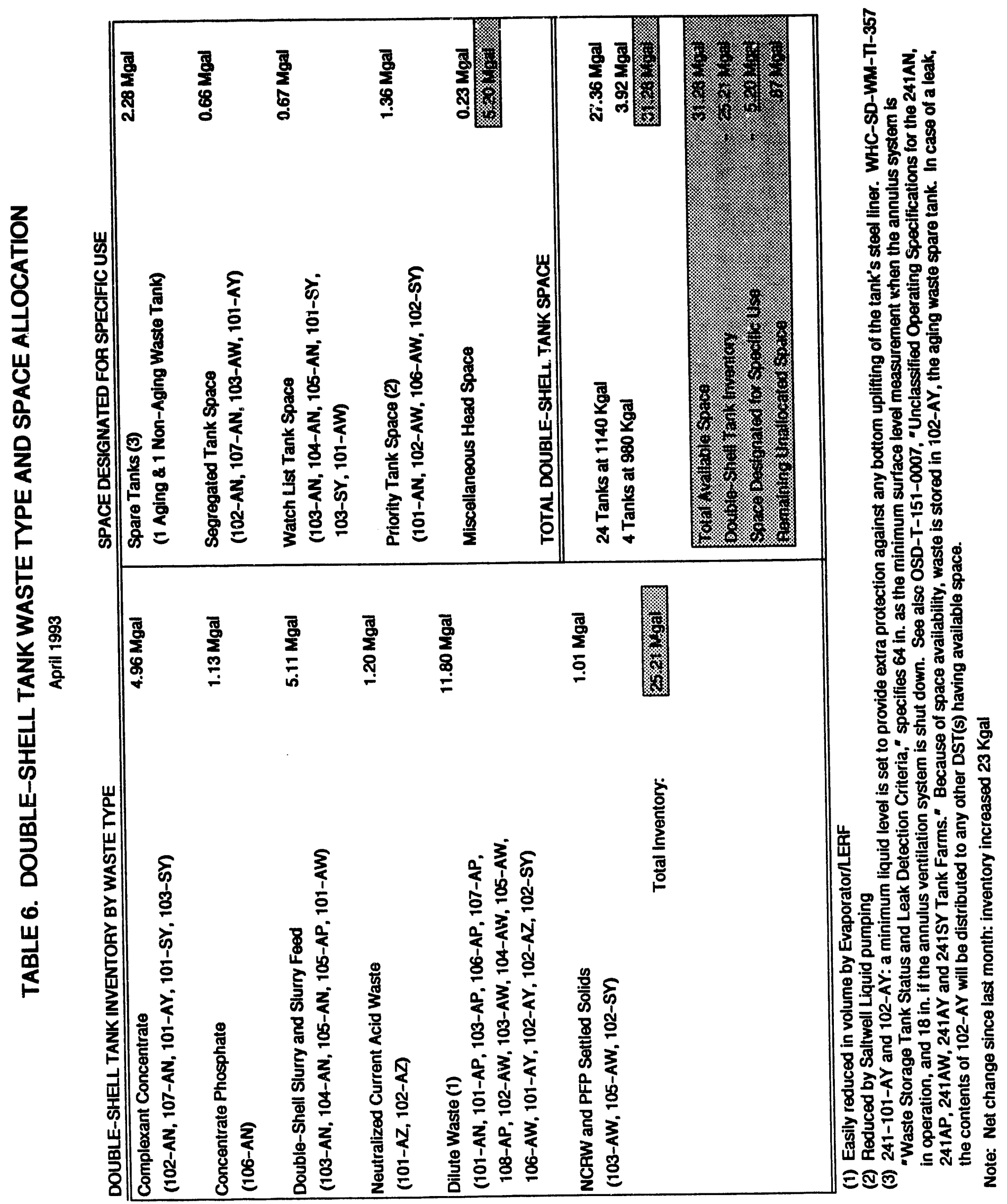



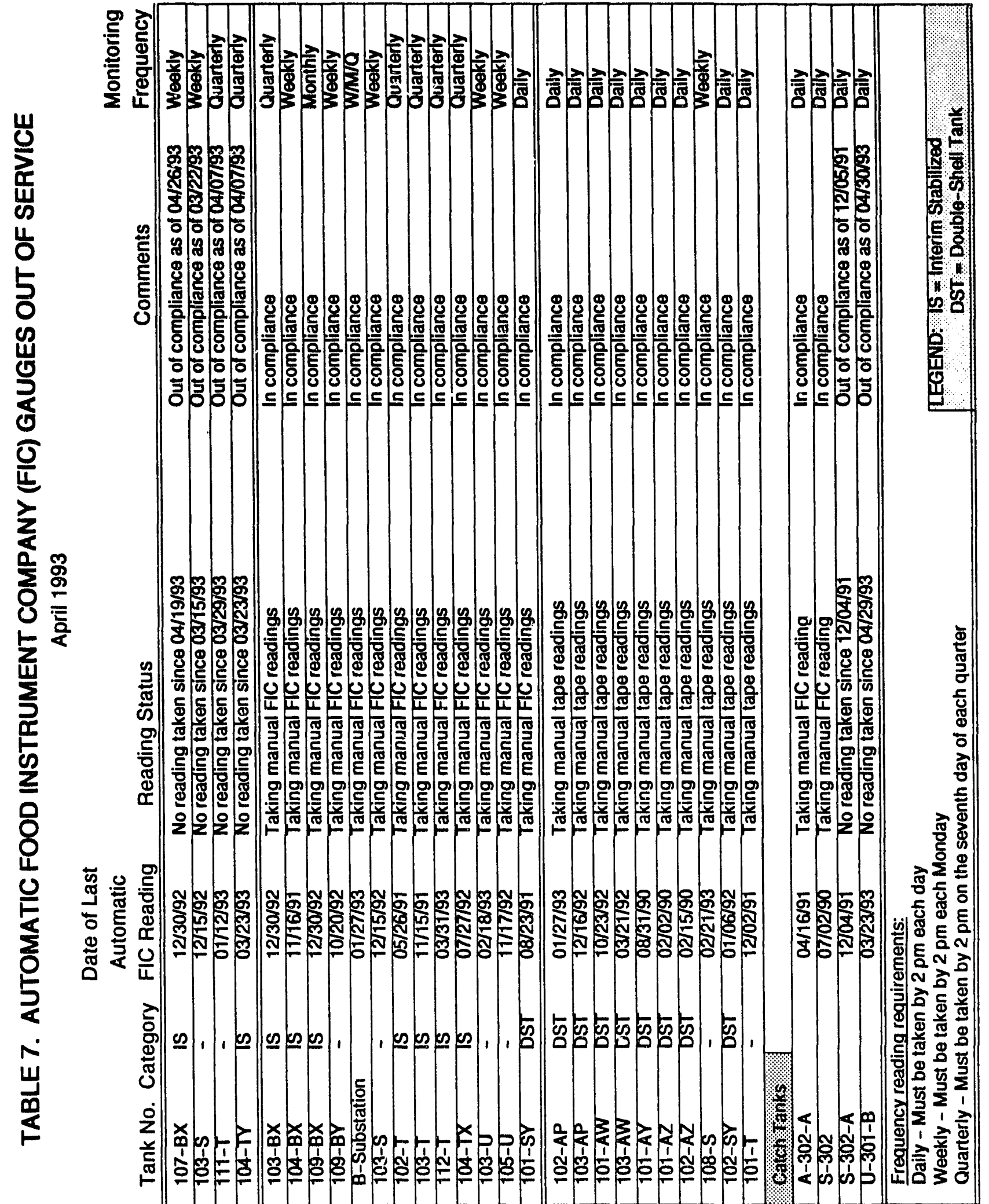


\section{TABLE 8. SINGLE-SHELL TANKS MONITORING COMPLIANCE STATUS 149 TANKS (Sheet 1 of 5)}

The following table indicates whether Single-Shell tank monitoring is in compliance with the requirements as specified in the applicable documents:

NOTE:

All Watch List and High Heat tank temperature monitoring is in compliance.

All Dome Elevation Survey monitoring is in compliance.

All Drywell monitoring is in compliance.

Psychrometrics (2)

In-tank Photographs (3)

\begin{tabular}{|c|c|}
\hline \multicolumn{2}{|l|}{ LEGEND: } \\
\hline 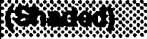 & = In compliance with all applicable documentation \\
\hline OKC & = Out of complianse with documentation \\
\hline-357 & $\begin{aligned}= & \text { WHC-SD-WhP-Th-357, "Waete Storage Tank Status and Leak } \\
& \text { Detection Criteria" }\end{aligned}$ \\
\hline POP & $\begin{array}{l}\text { - Plant Operating Procedure TO-040-650, "Obtain/Record SST } \\
\text { Temperaturee" }\end{array}$ \\
\hline M.T. & = Manual Tape \\
\hline FIC & = Food Inatrument Company \\
\hline OSPSAR & $\begin{array}{l}\text { = Operations Safety Requiremente/Safoty Analyeis Roport } \\
\text { Requiremente }\end{array}$ \\
\hline OSD & = Operating Specifications Document \\
\hline NMA & = Not Applicable (1.e., no LOW, M.T, FiC installed) \\
\hline O/S & $=$ Out of Service \\
\hline Gamma & = LOW readings taken by Gamma probe \\
\hline Noutron & = LOW readings taken by Neutron probe \\
\hline
\end{tabular}

Information as of $4 / 30 / 93$

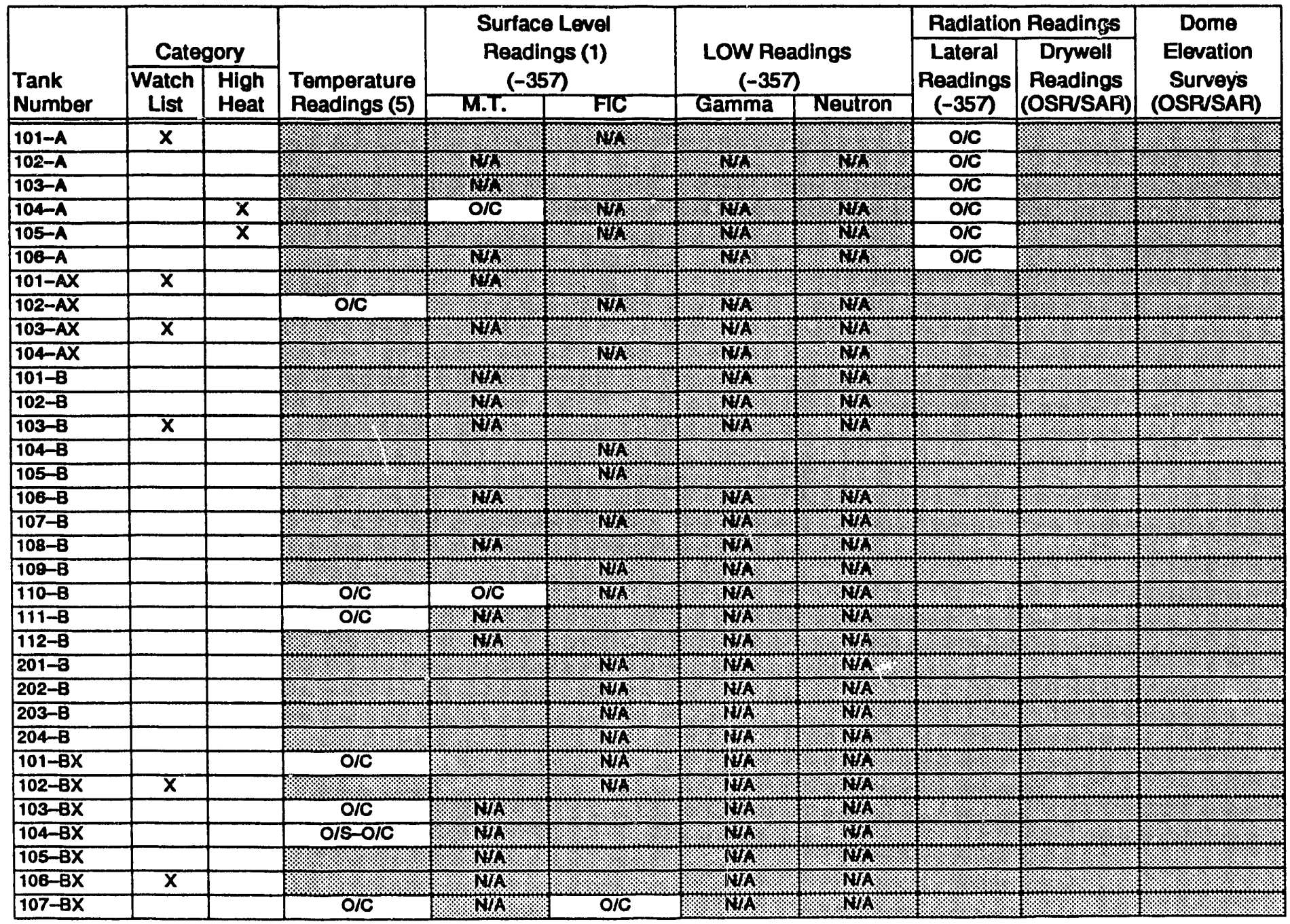


TABLE 8. SINGLE-SHELL TANKS MONITORING COMPLIANCE STATUS

149 TANKS (Sheet 2 of 5)

Information as of $4 / 30 / 93$

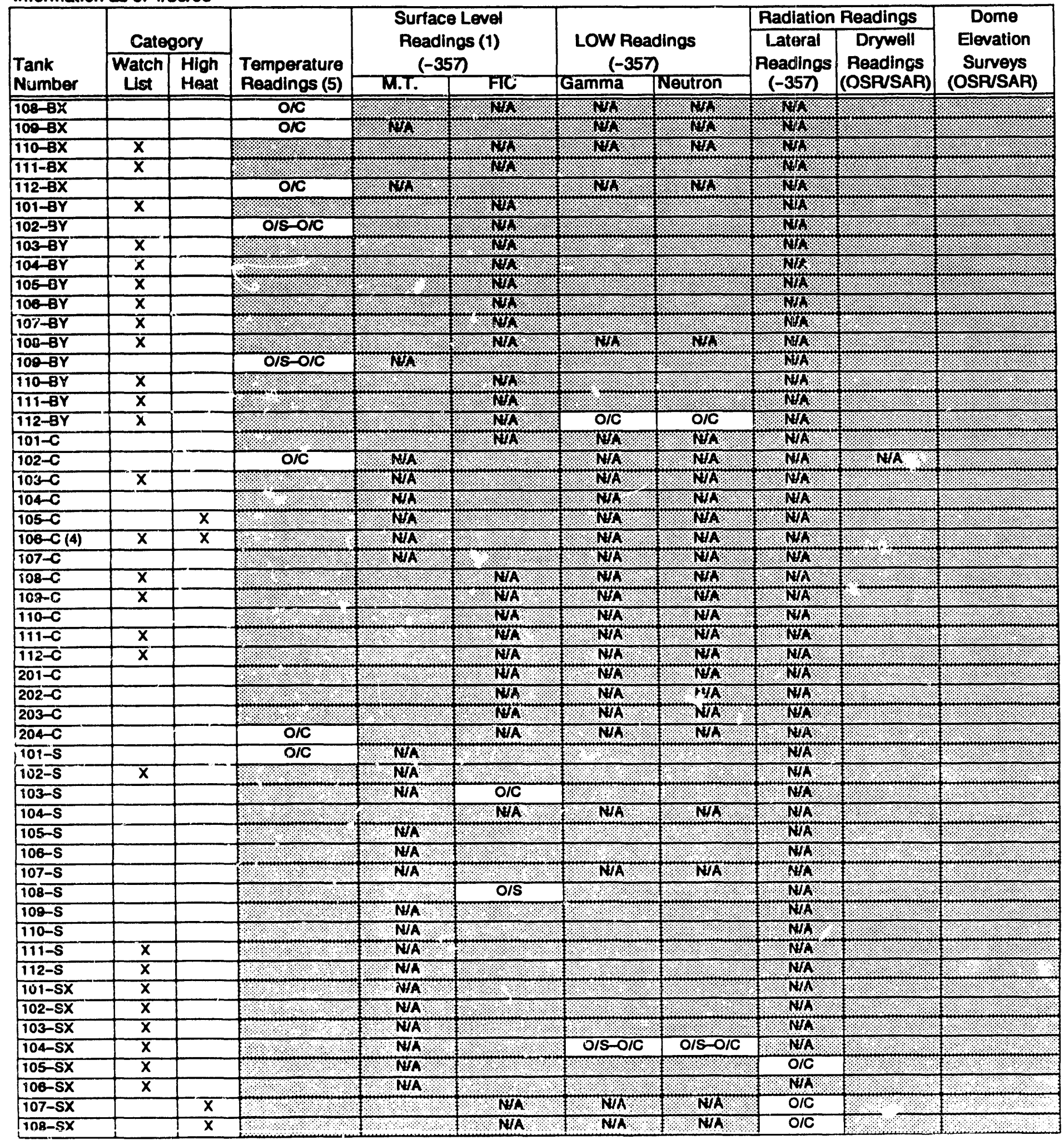


WHC-EP-0182-61

TABLE 8. SINGLE-SHELL TANKS MONITORING COMPLIANCE STATUS 149 TANKS (Sheet 3 of 5)

Information as of $4 / 30 / 93$

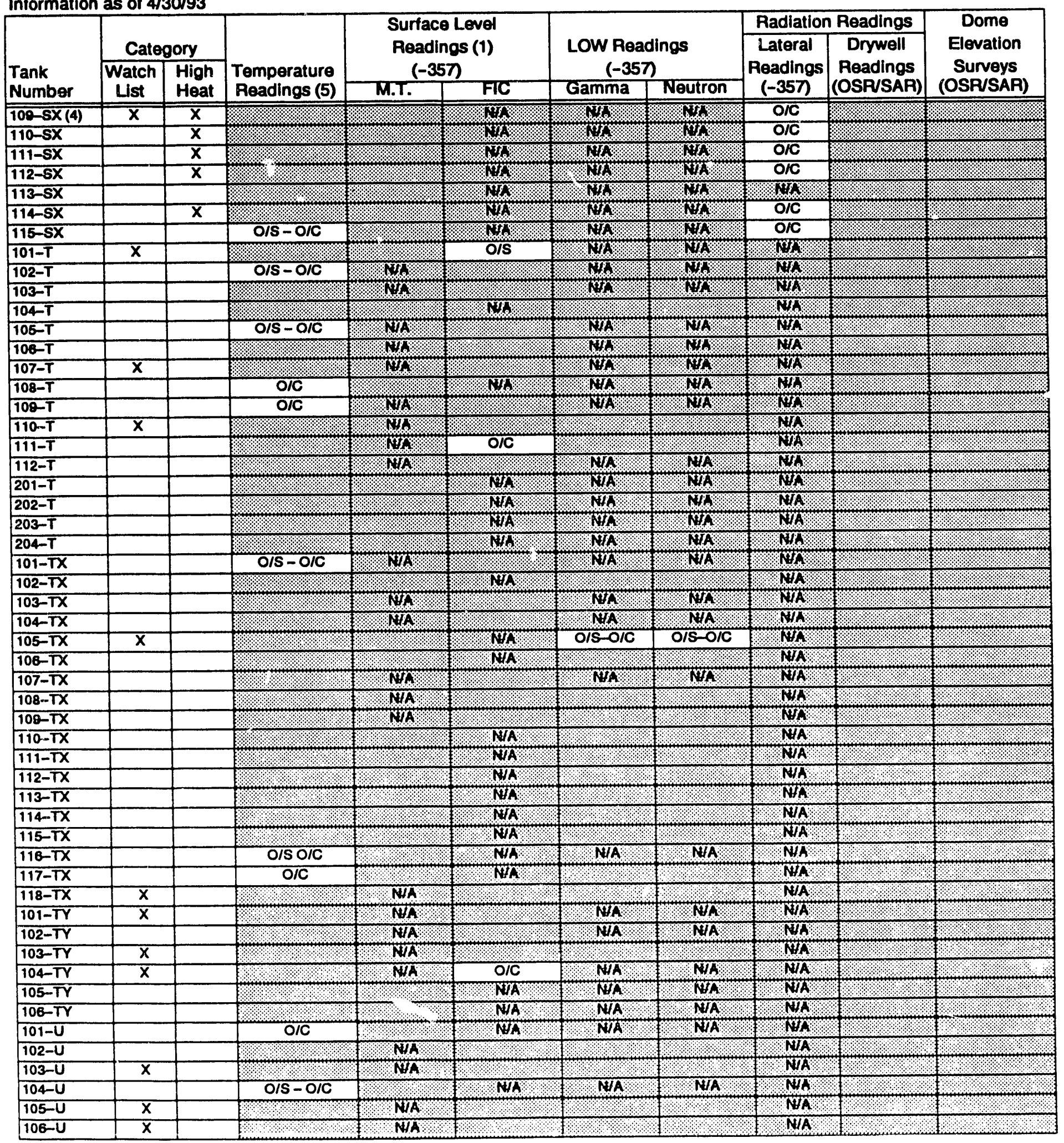




\section{TABLE 8. SINGLE-SHELL TANKS MONITORING COMPLIANCE STATUS 149 TANKS (Sheet 4 of 5)}

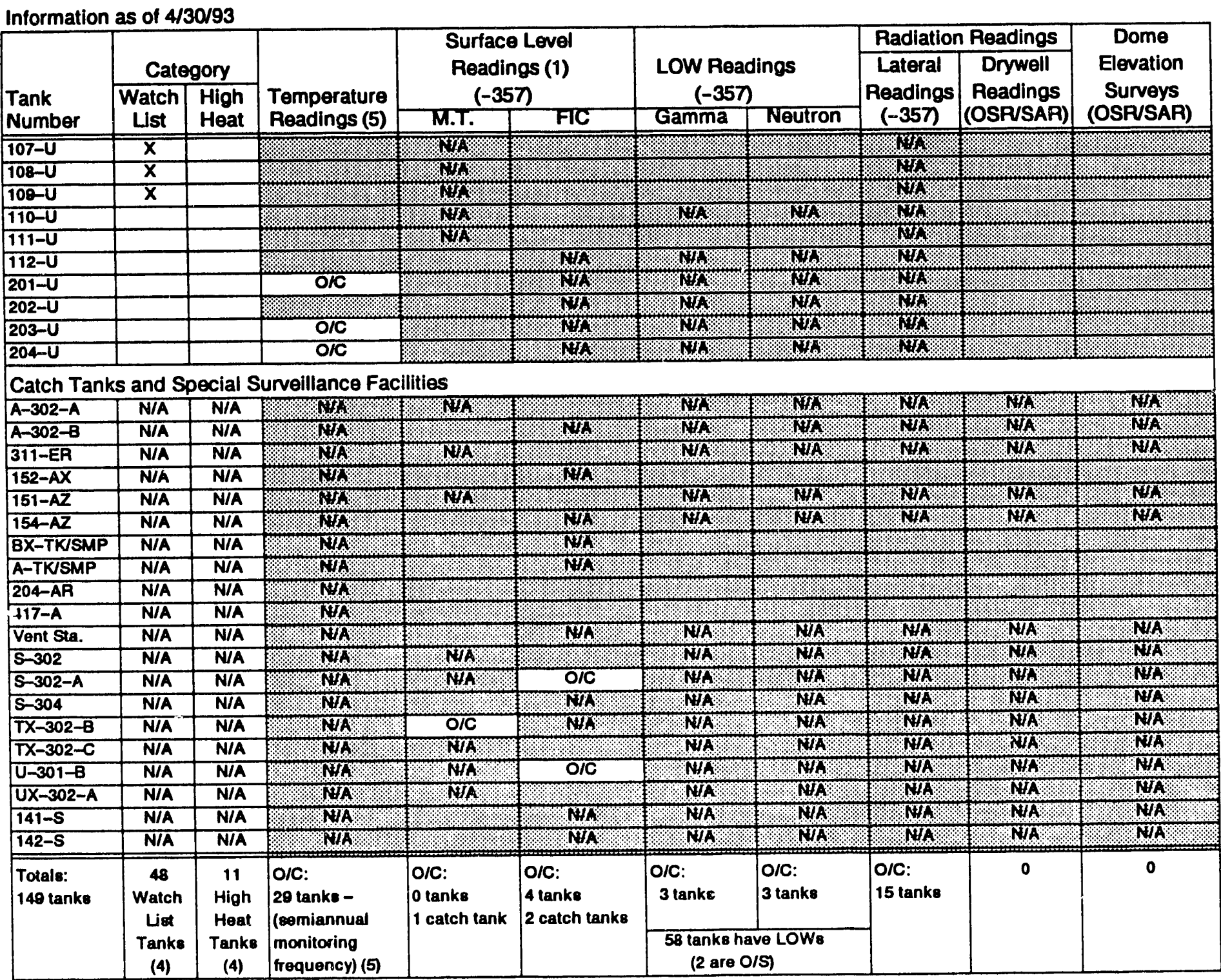

\section{Footnotes:}

(1) All SSTs have either manual tape or FIC, with the exception of 108-S and 101-T, which have both. Tank 101-T also has a zip cord. All SST FICs are connected to CASS, with the exception of 106-BX; however, the connection for many tan's is broken. For such cases, manual readings are taken. Manual surface level readings include readings taken by manual tape, manual FIC (not connected to Computer Automated Surveillance System, 106-BX), manual readings of automatic FIC (if CASS is printing " $O^{*}$ ), or automatic FIC. In some cases, the surface level readings are taken using a zip cord. While less accurate, such readings are acceptable for meeting the surface level reading requirements.

(2) Psychrometric readings are to be taken on tanks with active exhausters (High heat tanks 104/105-A, 105/106-C, 107, 108, 109, 110,111,112, and 114-SX). Psychrometrics were not taken from 9/91 to 9/92. Exhauster down on 104/105-A; no readings being taken. 105/106-C psychrometric readings are required to be taken on a monthly frequency. Readings were taken in high heat SX tanks in March 1993. Psychrometic frequency not specified in -357 or operating procedures.

(3) in-lank Photographs are not required by -357. In-tank photographs were not taken between 1991 and 1993.

(4) Two tanks are on both category lists (106-C, 109-SX). 


\section{TABLE 8. SINGLE-SHELL TANKS MONITORING COMPLIANCE STATUS 149 TANKS (Sheet 5 of 5 )}

\section{Footnotes continued:}

(5) Temperature readings may be regulated by OSD, -357 , or POP. Additionally, high heat load tanks are regulated by OSPVSAR. Thermcouples in the 9 tanks designated O/S-O/C are out of service; there are either no thermocouple probes in these tanks, or probes have been cut off, covered over, or are otherwise unable to function. The OSD does not require readings or repair of out-of-service thermocouples for the 92 non-heat load ( $>40,000 \mathrm{Btu} / \mathrm{hr})$ tanks. However, operating procedure (POP) requires that attempts are to be made semiannually in January and July to obtain readings from these tanks. In March 1993, seven additional TX tank temperature readings were obtained by measuring resistance using the wall of the pipe as ground. Temperatures were comparable to last temperatures taken in 1983.29 tanks are O/C because either no attempts were made to read them January - March or readings could not be obtained. 


\section{TABLE 9. DOUBL.E-SHELL TANKS MONITORING COMPLIANCE STATUS 28 TANKS}

The following table indicates whether Double-Shell tank monitoring is in compliance with the requirements as specified in the applicable documents:

NOTE:

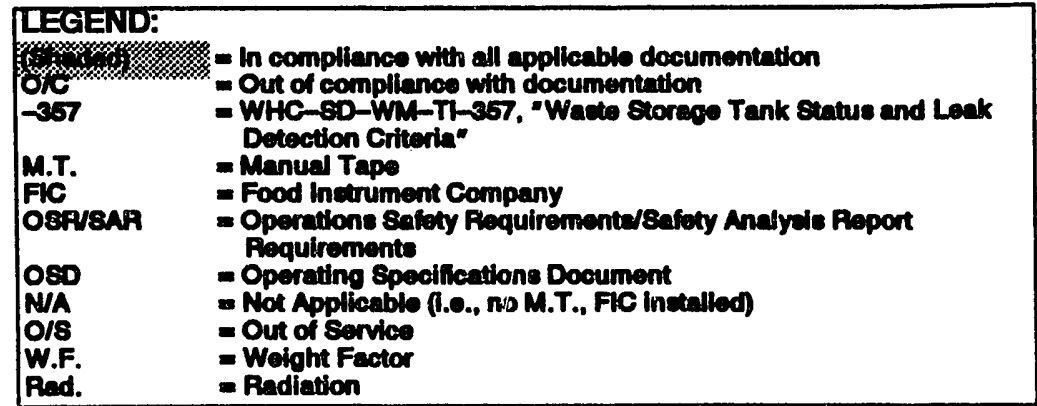

Information as of $4 / 30 / 93$

\begin{tabular}{|c|c|c|c|c|c|c|c|}
\hline \multirow{3}{*}{$\begin{array}{l}\text { Tank } \\
\text { Number }\end{array}$} & \multirow[b]{3}{*}{ Watch List } & \multirow{3}{*}{\begin{tabular}{|c|} 
Temperature \\
Readings \\
$(4)$ \\
(OSD)
\end{tabular}} & \multirow{2}{*}{\multicolumn{2}{|c|}{$\begin{array}{l}\text { Surface Level } \\
\text { Readings (1) } \\
\text { (-357, OSP/SAP) }\end{array}$}} & \multicolumn{3}{|c|}{ Radiation Readings } \\
\hline & & & & & \multicolumn{2}{|c|}{$\begin{array}{c}\text { Leak Detection } \\
\text { Pits (5) } \\
(-357 . \text { OSR SAR) }\end{array}$} & \multirow{2}{*}{$\begin{array}{c}\text { Annulus } \\
(-357)\end{array}$} \\
\hline & & & M.T. & FIC & W.F. & Rad. & \\
\hline $101-A N$ & & & 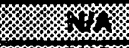 & & & & \\
\hline 102-AN & & & 42 & & 多帘 & O/C & \\
\hline $103-A N$ & $\bar{x}$ & & 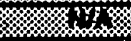 & & & 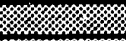 & 奖 \\
\hline 104-AN & $\bar{x}$ & & m & & & 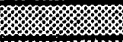 & \\
\hline 105-AN & $\bar{x}$ & & 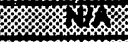 & & & & \\
\hline $100-A N$ & & & W & & & & \\
\hline $107-A N$ & & & 8 & & & & \\
\hline 101-AP & & & & & & ONC & \\
\hline 102-AP & & & & $0 / 8$ & & OKC & \\
\hline 103-AP & & & & O/S & & OK & \\
\hline 104-AP & & & $0 / 8$ & & & OKC & \\
\hline 105-AP & & OrC & & & & OKC & \\
\hline 100-AP & & OKC & & & & OKC & \\
\hline 107-AP & & O/C & & & & OKC & \\
\hline 108-AP & & OMC & & & & OKC & \\
\hline 101-AW & $\bar{x}$ & & & $0 / 8$ & & 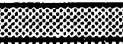 & \\
\hline \multicolumn{8}{|l|}{$102-A W$} \\
\hline \multicolumn{8}{|l|}{ 108-AW } \\
\hline \multicolumn{8}{|l|}{ 104-AW } \\
\hline 105-AW & & & & o/s & & & \\
\hline \multicolumn{8}{|l|}{$10 \theta-A W$} \\
\hline $101-A Y$ & & & & O/S & & & $O K C$ \\
\hline 102-AY & & & & & & OK & O/C \\
\hline $101-A Z$ & & & & $0 / 5$ & m & OrC & \\
\hline $102-\wedge Z$ & & & & O/S & & . & \\
\hline 101-SY & $\bar{x}$ & & & & & & \\
\hline 102-SY & & & & O/S & & & \\
\hline 103-SY & $x$ & & & & & & \\
\hline $\begin{array}{l}\text { Totale: } \\
28 \text { tanke }\end{array}$ & $\stackrel{6}{\text { Watch List Tanks }}$ & $\begin{array}{l}\text { O/C: } \\
4(4)\end{array}$ & $\begin{array}{l}\text { ONC: } \\
0\end{array}$ & $\begin{array}{l}\text { ORC: } \\
0\end{array}$ & $\begin{array}{l}\text { Orc: } \\
0\end{array}$ & $\begin{array}{l}\text { O/C: } \\
11 \text { tanks }\end{array}$ & $\begin{array}{l}\text { O/C: } \\
2 \text { tanks }\end{array}$ \\
\hline
\end{tabular}

(1) All DSTs have both manual tape and FIC, with the exception of the AN Tank Farm which only has FICs. The manual tape is used when the FIC is out of service. O/C will be shown when no readings are obtained.

(2) Psychrometric readings are taken on DSTs. All DSTs are equipped with active exhausters. Psychrometrics were not taken from 9/91 to 9/92; readings on some tanks were resumed beginning October 1992. Frequency of psychrometric monitoring is not specified in -357 or operating procedures.

(3) in-tank photographs are not required by -357. Last in-tank photographs in DSTs were taken April 1989.

(4) OSD requires DST temperatures to be taken weekly. Tank 101-SY temperatures are obtained shiftwise with increased readings taken prior to and following gas venting. Four AP tanks are O/C because the transmitting equipment is O/S.

(5) Failure of both leak detection systems requires repair of at least one system within 5 working days. Failure of one system only, repait must ba within 10 working days. Per -357 . If repair of out-of-senice systems exceeds these timetrames, systems are O/C. Out-of-service systems which have not exceeded these timeframes will be shown as O/S.

- Although data is being received for $101-A Z$, it is considered questionable. 
WHC-EP-0182-61

\section{APPENDIX A}

\section{TANK AND EQUIPMENT CODE} AND STATUS DEFINITIONS 
WHC-EP-0182-61

This page intentionally left blank 


\section{TANK AND EQUIPMENT CODE/STATUS DEFINITIONS}

Apri 11993

\section{TANK STATUS CODES}

\section{WASTE TYPE}

$\begin{array}{ll}\text { AGING } & \text { Aging Waste (Neutralized Current Acid Waste [NCAW]) } \\ \text { CC } & \text { Complexant Concentrate Waste } \\ \text { CP } & \text { Concentrated Phosphate Waste } \\ \text { DC } & \text { Dilute Complexed Waste } \\ \text { DN } & \text { Dilute Non-Complexed Waste } \\ \text { DSS } & \text { Double-Shell Slurry } \\ \text { DSSF } & \text { Double-Shell Slurry Feed } \\ \text { NCPLX } & \text { Non-Complexed Waste } \\ \text { PD/PN } & \text { Plutonium-Uranium Extraction (PUREX) Neutralized Cladding } \\ & \text { Removal Waste (NCRW) transuranic waste (TRU) } \\ \text { PT } & \text { Plutonium Finishing Plant (PFP) TRU Solids }\end{array}$

\section{TANK USE (DOUBLE-SHELL TANKS ONLY)}

$\begin{array}{ll}\text { CWHT } & \text { Concentrated Waste Holding Tank } \\ \text { DRCVR } & \text { Dilute Receiver Tank } \\ \text { EVFD } & \text { Evaporate Feed Tank } \\ \text { GRTFD } & \text { Grout Feed Tank } \\ \text { SRCVR } & \text { Slurry Receiver Tank }\end{array}$

2. SOLID AND LIQUID VOLUME DETERMINATION METHODS

$\begin{array}{ll}\text { F } & \text { Food Instrument Company (FIC) Automatic Surface Level Gauge } \\ \text { M } & \text { Manual Tape Surface Level Gauge } \\ \text { P } & \text { Photo Evaluation } \\ S & \text { Sludge Level Measurement Device }\end{array}$

\section{DEFINITIONS}

\section{WASTE TANKS - GENERAL}

$\begin{array}{ll}\text { Waste Tank } & \begin{array}{l}\text { A potentially unsafe condition in the handling of } \\ \text { Safety Issue }\end{array} \\ \text { waste material in underground storage tanks that } \\ \text { requires corrective action to reduce or eliminate } \\ \text { the unsafe condition }\end{array} \quad \begin{aligned} & \text { An underground storage tank containing waste that } \\ & \text { requires special safety precautions because it may } \\ & \text { have a serious potential for release of high level } \\ & \text { radioactive waste because of uncontrolled increases } \\ & \text { in temperature or pressure. Special restrictions } \\ & \text { have been placed on these tanks by "Safety Measures } \\ & \text { for Waste Tanks at Hanford Nuclear Reservation, } \\ & \text { Section } 3137 \text { of the National Defense Authorization } \\ & \text { Act for Fiscal Year 1991, November } 5,1990, \text { Public } \\ & \text { Law 101-510, (also known as the Wyden Amendment). }\end{aligned}$




\section{HASTE TYPES}

Aging Waste (AGING)

Concentrated

Complexant (CC)

Concentrated

Phosphate Waste (CP)

Dilute Complexed Waste (DC)
High level, first cycle solvent extraction waste from the PUREX plant (NCAW)

Concentrated product from the evaporation of dilute complexed waste.

Waste originating from the decontamination of $100 \mathrm{~N}$ Area reactor. Concentration of this waste produces concentrated phosphate waste.

Characterized by a high content of organic carbon including organic complexants:

ethylenediaminetetra-acetic acid (EDTA), citric acid, hydroxyethyl-ethylenediaminetriacetic acid (HEDTA), and iminodiacetate (IDA) being the major complexants used. Main sources of DC waste in the DST system are saltwell liquid inventory.

Dilute Non-Complexed Waste (DN)

Low activity liquid waste originating from $T$ and $S$ Plants, the 300 and 400 Areas, PUREX facility (decladding supernatant and miscellaneous wastes), $100 \mathrm{~N}$ Area (sulfate waste), B Plant, saltwells, and PFP (supernate).

Double-Shel1

Slurry (DSS)

Double-She11 Slurry Feed (DSSF)

Non-complexed (NCPLX)

PUREX Decladding $(P D / P N)$

PFP TRU Solids (PT)

Drainable Interstitial Liquid (DIL)

\section{Supernate}

Waste that exceeds the sodium aluminate saturation boundary in the evaporator without exceeding receiver tank composition limits. For reporting purposes, DSS is considered a solid.

Waste concentrated just before reaching the sodium aluminate saturation boundary in the evaporator without exceeding receiver tank composition limits. This form is not as concentrated as DSS.

General waste term applied to all Hanford site liquors not identified as complexed.

PUREX Neutralized Cladding Removal Waste (NCRW) is the solids portion of the PUREX plant neutralized cladding removal waste stream; received in Tank Farms as a slurry. NCRW solids are classified as transuranic (TRU) waste.

TRU solids fraction from PFP Plant operations.

Interstitial liquid that is not held in place by capillary forces, and will therefore migrate or move by gravity.

The liquid above the solids in waste storage tanks. 
Ferrocyanide

WASTE STATUS
A compound of iron and cyanide commonly expressed as FeCN. The actual formula for the ferrocyanide anion is $\left[\mathrm{Fe}(\mathrm{CN})_{6}\right]^{-4}$.
In-Service Tank
Out-of-Service Tank
The waste classification of a tank being used, or planned for use, for the storage of liquid (in excess of a minimum supernatant liquid heel) in conjunction with production and/or waste processing.
A tank which does not meet the definition of an in- service tank. Before September 1988, these tanks were defined as inactive in this report. [Note: All single-shell tanks (SST) are out of service.]

\section{STABILIZATION (Single-Shell Tanks only)}

Interim

Stabilized

(IS)

\begin{abstract}
A tank which contains less than 50,000 gal of drainable interstitial liquid and less than 5,000 gal of supernatant liquid. If the tank was jet pumped to achieve interim stabilization, then the jet pump flow must also have been at or below $0.05 \mathrm{gpm}$ before interim stabilization criteria is met.
\end{abstract}

\section{ISOLATION (Single-Shell Tanks only)}

Partially

Interim Isolated (PI)

Interim Isolated (II)

\section{TANK INTEGRITY}

Sound

Assumed Leaker

Assumed Re-Leaker
The administrative designation reflecting the completion of the physical effort required for Interim Isolation except for isolation of risers and piping that is required for jet pumping or for other methods of stabilization.

The administrative designation reflecting the completion of the physical effort required to minimize the addition of liquids into an inactive storage tank, process vault, sump, catch tank, or diversion box.

The integrity classification of a waste storage tank for which surveillance data indicate no loss of liquid attributed to a breach of integrity.

The integrity classification of a waste storage tank for which surveillance data indicate a loss of 1 iquid attributed to a breach of integrity.

A condition that exists after a tank has been declared as an "assumed leaker" and then the surveillance data indicates a new loss of liquid attributed to a breach of integrity. 
TANK INVESTIGATION

Intrusion

A term used to describe the infiltration of liquid into a waste tank.

\section{SURVEILLANCE INSTRUMENTATION}

Drywe11s

Laterals

Surface Levels

Automatic FIC

Annulus
Drywells are vertical boreholes with 6-in. (internal diameter) carbon steel casings positioned radially around SSTs. Periodic monitoring is done by gamma radiation or neutron sensors to obtain scan profiles of radiation or moisture in the soil as a function of well depth, which could be indicative of tank leakage. These wells range between 50 and $250 \mathrm{ft}$ in depth, and are monitored between the range of 50 to $150 \mathrm{ft}$. The wells are sealed when not in use. They are called drywells because they do not penetrate to the water table and are therefore usualiy "dry." The drywell frequency monitoring schedule calls for 105 drywells weekly, 91 biweekly, 41 monthly, 151 quarterly, and 371 annually.

Laterals are horizontal drywells positioned under single-shell waste storage tanks to detect radionuclides in the soil which could be indicative of tank leakage. These drywells are monitored by radiation detection probes. Laterals are 4-in. inside diameter steel pipes located 8 to $10 \mathrm{ft}$ below the tank's concrete base. There are three laterals per tank. Laterals are located only in $A$ and $S X$ farms.

The surface level measurements in all waste storage tanks are monitored by manual or automatic conductivity probes, and recorded and transmitted or inputted to the Computer Automated Surveillance System (CASS).

An automatic waste surface level measurement device is manufactured by the Food Instrument Company (FIC). The instrument consists of a conductivity electrode ( $p$ lummet) connected to a calibrated steel tape, a steel tape reel housing and a controller that automatically raises and lowers the plummet to obtain a waste surface level reading. The controller can provide a digital display of the data and also transmit the reading to the CASS. Some tanks have gauges connected to CASS and others are read manualiy.

The annulus is the space between the inner and outer shells on DSTs. Drain channels in the insulating and/or supporting concrete carry any leakage to the annulus space where conductivity probes are 
Liquid Observation Well (LOW)

Thermocouple (TC)

In-tank

Photography installed. Alarms from the annunciators are received by CASS. Continuous Air Monitoring (CAM) alarms are al so located in the annulus. The annulus conductivity probes and radiation detectors are the primary means of leak detection for all DSTs.

In-tank liquid observation wells are used for monitoring the interstitial liquid level (ILL) in single-shell waste storage tanks. The wells are constructed of fiberglass or TEFZEL*-reinforced epoxy-polyester resin, sized to extend to within 1 in. of the bottom of the tank steel liner. They are sealed at their bottom ends and have a nominal outside diameter of $3.5 \mathrm{in}$. Three probes are used to monitor changes in the ILL: acoustic; gamma; and neutron, which can indicate intrusions or leakage by increases or decreases in the ILL. There are 58 LOWs (56 are in operation) installed in SSTs that contain or are capable of containing greater than 50,000 gal of drainable interstitial i iquid, and in two DSTs only. The LOWs installed in two DSTs, (102-SY and 103-AW Tanks), are constructed of stee 1 and are used for special surveillance purposes only.

A thermocouple is a thermoelectric device used to measure temperature. More than one thermocouple on a device (probe) is called a thermocouple tree. In DSTs there may be one or more thermocouple trees in risers in the primary tank. In addition, in DSTs only, there are thermocouple elements installed in the insulating concrete, the lower primary tank knuckle, the secondary tank concrete foundation, and in the outer structural concrete. These monitor temperature gradients within the concrete walls, bottom of the tank, and the domes. In SSTs, there may be one or more thermocouple trees installed directly in a tank, although some SSTs do not have any trees installed. A single thermocouple may be installed in a riser, or lowered down an existing riser or LOW. There are also four thermocouple laterals beneath Tank 105-A in which temperature readings are taken in 34 thermocouples.

In-tank photographs may be taken to aid in resolving in-tank measurement anomalies and determine tank integrity. Photographs help determine sludge and liquid levels by visual examination.

* TEFZEL, a trademark of E. I. du Pont de Nemours \& Company 
4. INVENTORY AND STATUS BY TANK - COLUMN CALCULATIONS (SINGLE-SHELL TANKS) COLUMN HEADING

Total Waste Solids Volume plus Supernatant liquid.

Supernatant Drainable Liquid Remaining minus Drainable Interstitial. Liquid Supernate is usually derived by subtracting the solids level measurement from the liquid level measurement.

Drainable

Drainable Liquid Remaining minus Supernate.

Interstitial

Drainable Interstitial Liquid is calculated based on the saltcake and sludge volumes, using average porosity values or actual data for each tank, when available.

Total Jet

Pumped

Cumulative total pumped 1979 to date.

Drainable Liquid Remaining

Pumpable Liquid Remaining

Sludge

Saltcake

Supernate plus Drainable Interstitial.

Drainable Liquid Remaining less undrainable heel volume.

Solids formed during sodium hydroxide additions to waste. Sludge usually was in the form of suspended solids when the waste was originally received in the tank from the waste generator. In-tank photographs may be used to estimate the volume.

Results from crystalization and precipitation after concentration of liquid waste, usually in an evaporator. If saltcake is layered over sludge, it is only possible to measure total solids volume. In-tank photographs may be used to estimate the saltcake volume.

Solids Volume Indicates the latest update of any change in the solids Update volume.

Solids Update Indicates the source or basis of the latest solids Source - See volume update.

Footnote

Last"Photo Date of latest in-tank photographs taken.

Date

Change Since Last Monthly Report

Indicates any change made since the previous month. Explanation for the change follows the Inventory and Status by Tank section. 
WHC-EP-0182-61

\section{APPENDIX B}

TANK FARM CONFIGURATION, STATUS, AND FACILITY CHARTS 
WHC-EP-0182-61

This page intentionally left blank.

B-2 

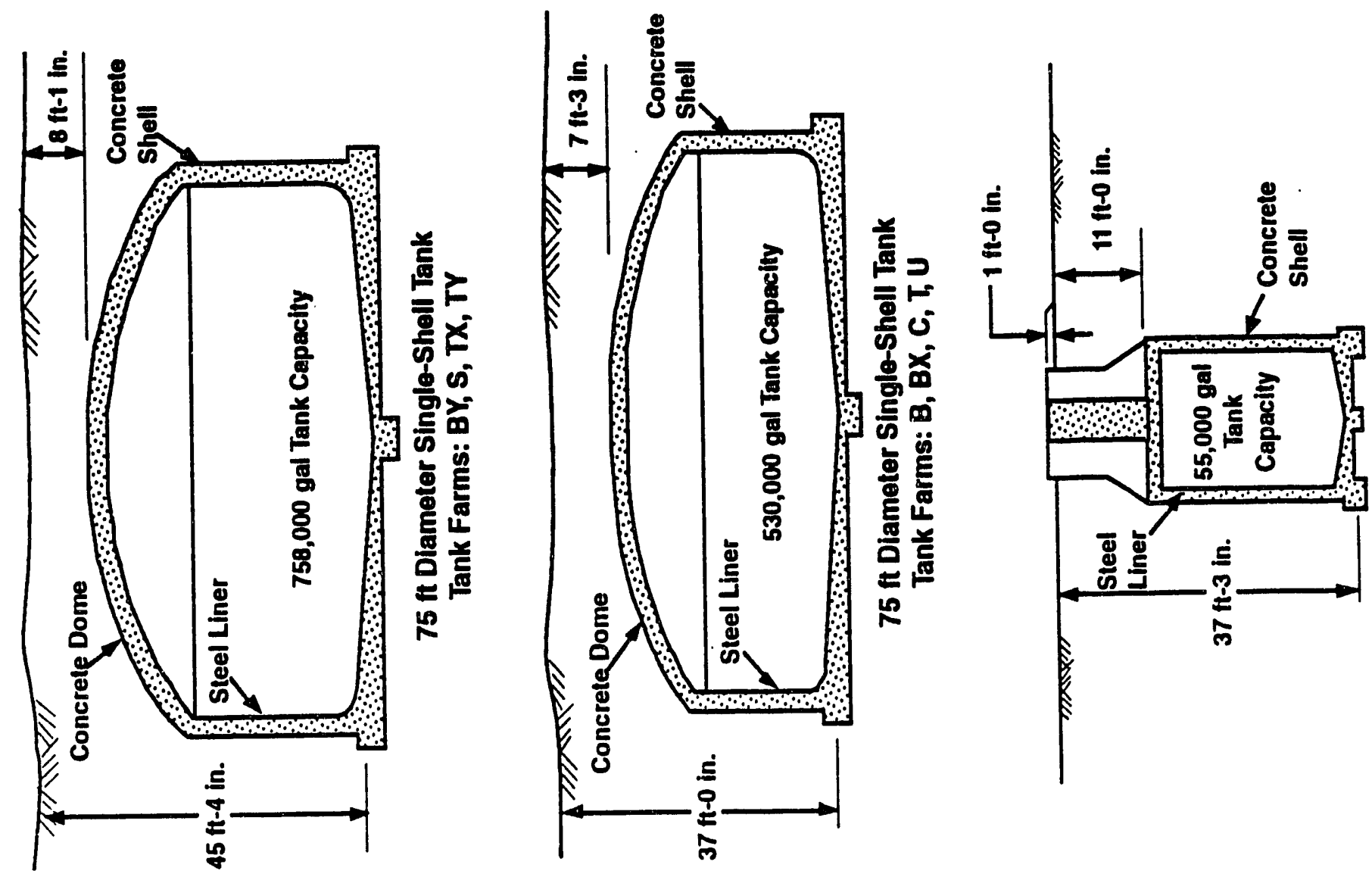

ํㅗㅇ
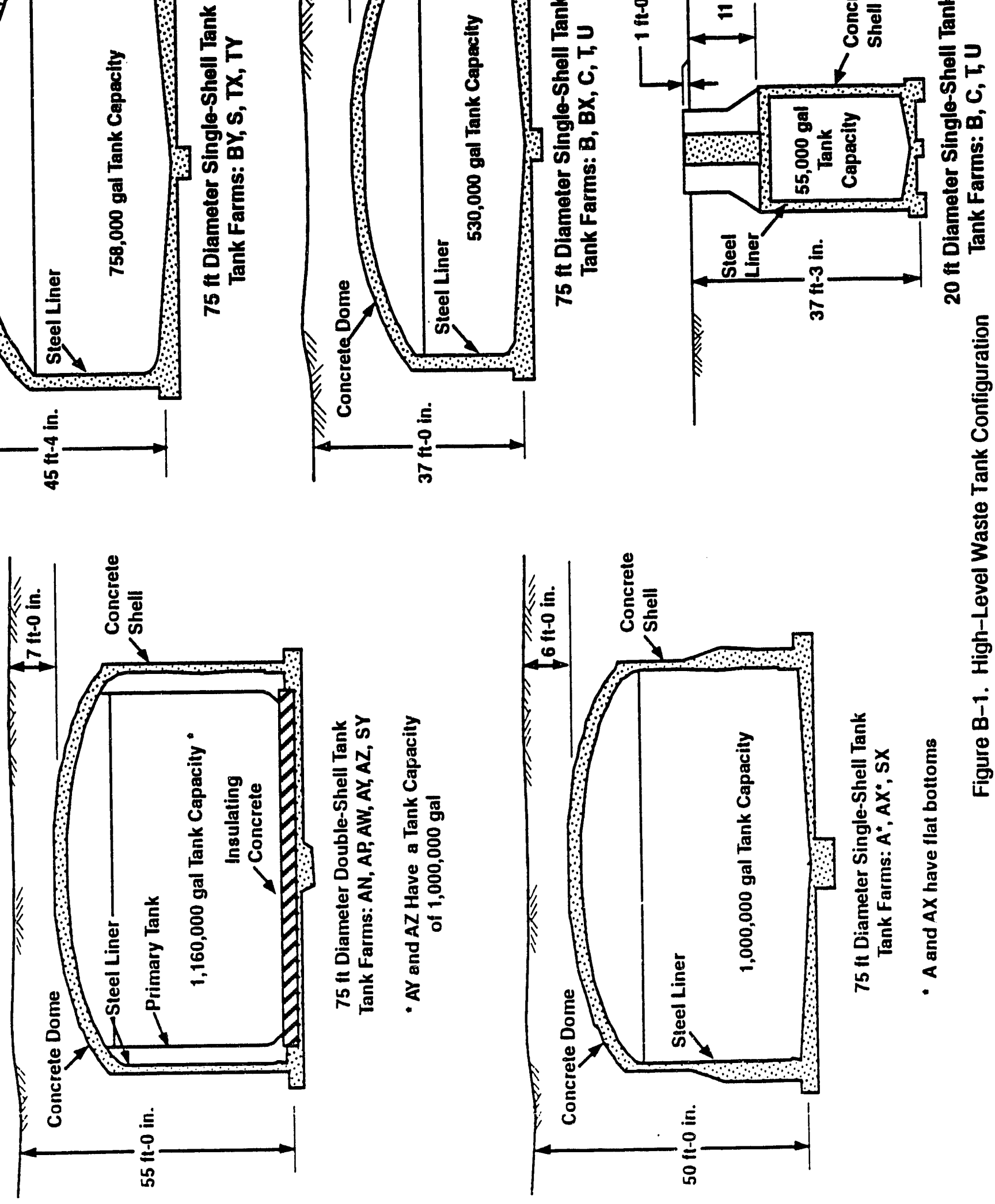

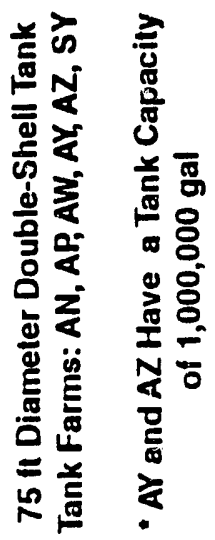
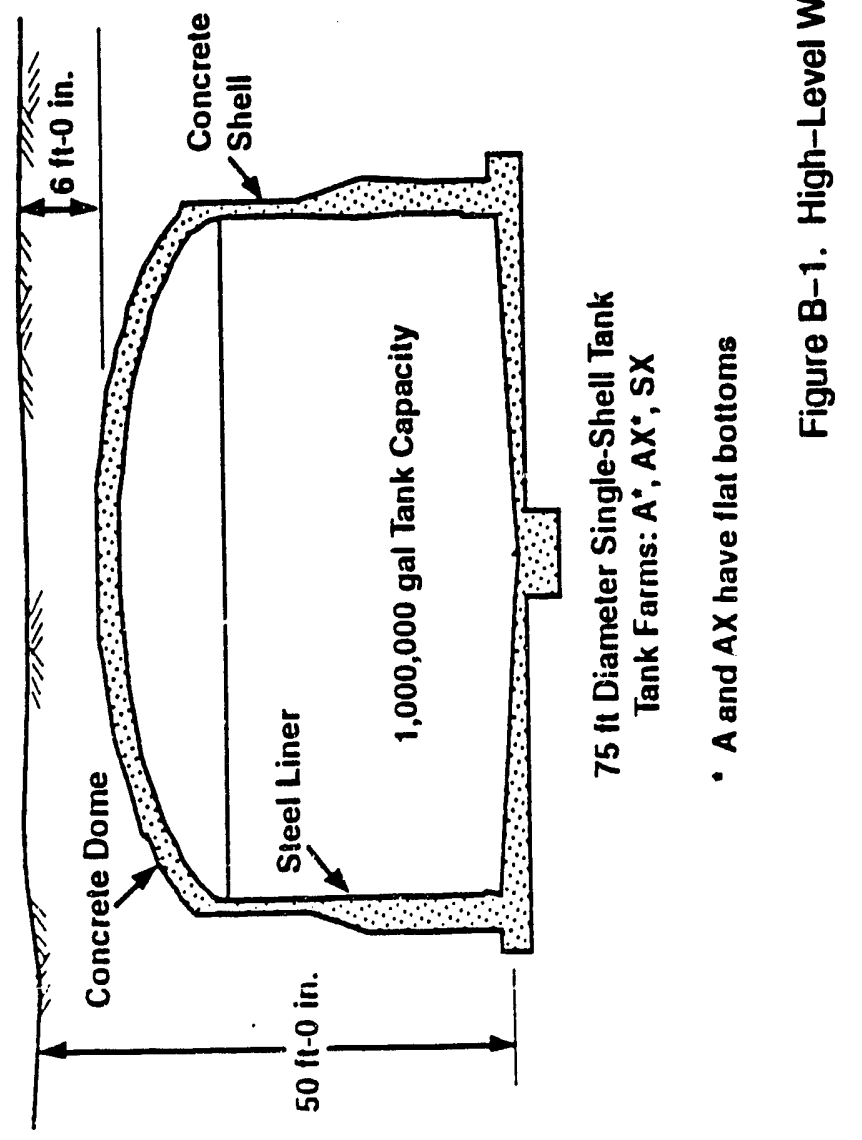


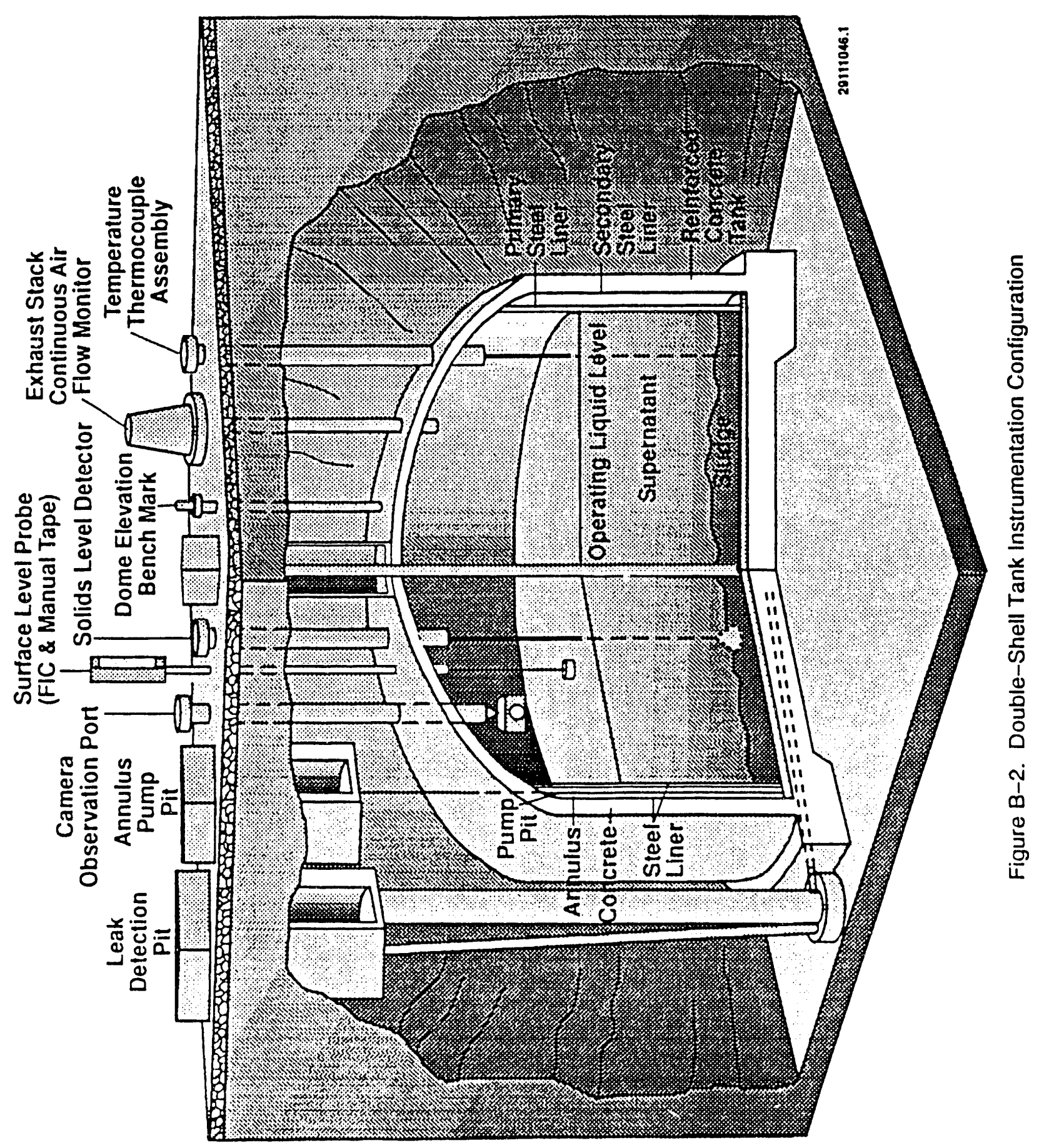




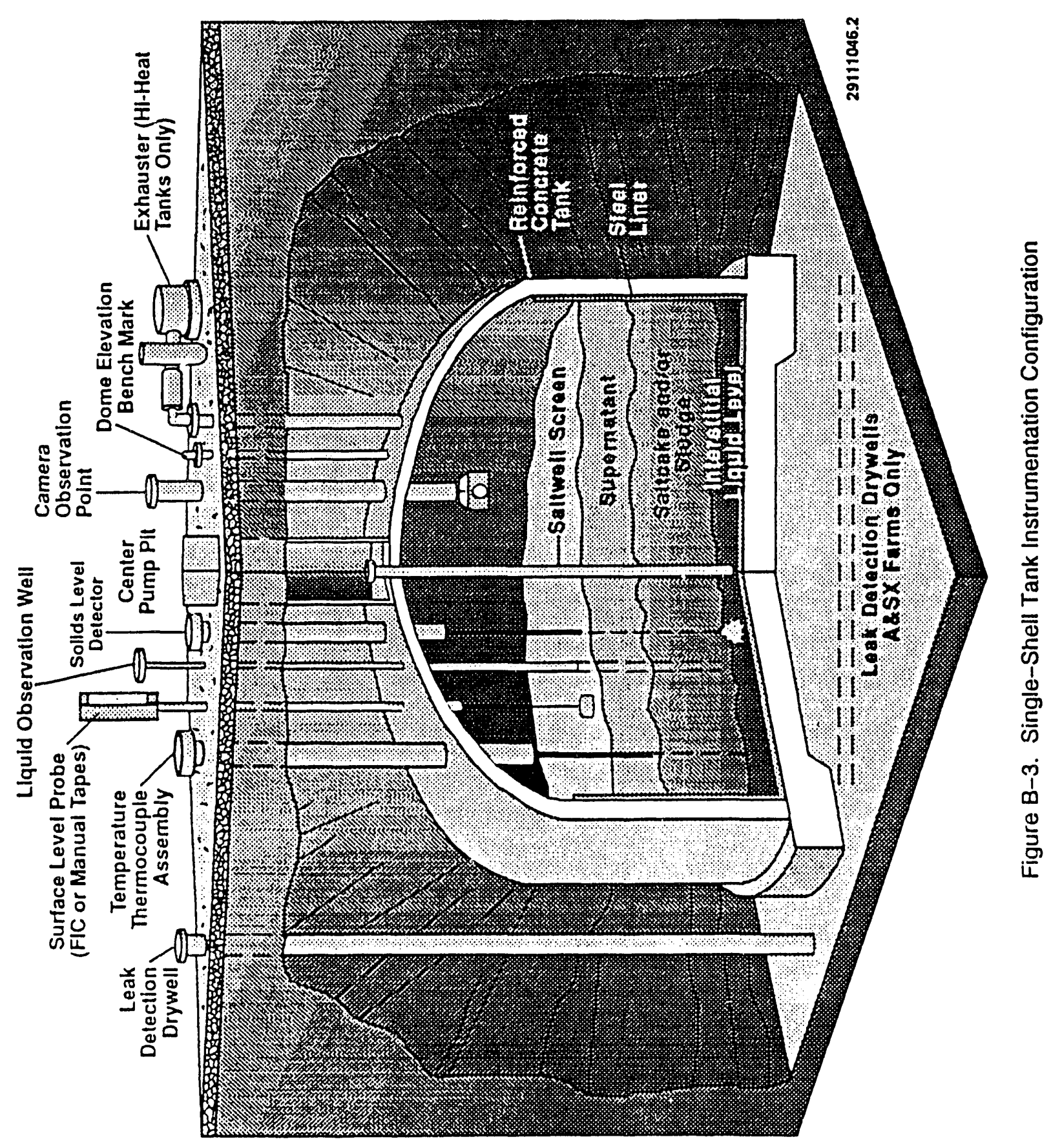




\section{WHC-EP-0182-61}

This page intentionally left blank. 


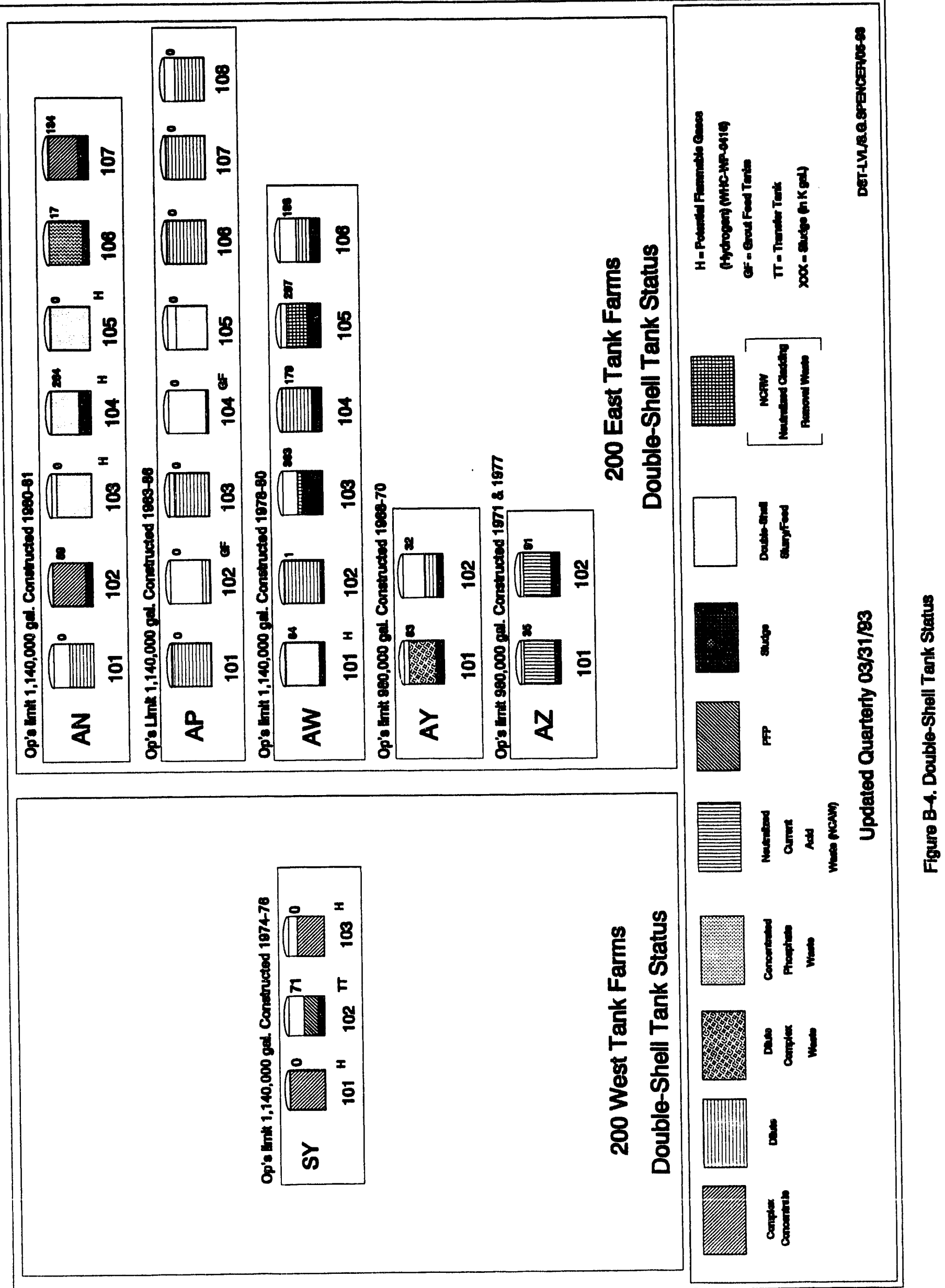


1,000,000 gal. tanks Construeted 185465

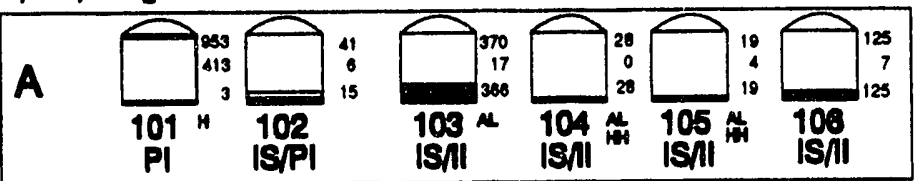

1,000,000 gal. tanlas Constructed 1909-64

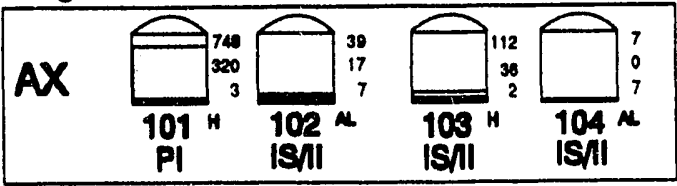

$500,000 \mathrm{gal}$ tanke Constructed 1945-44

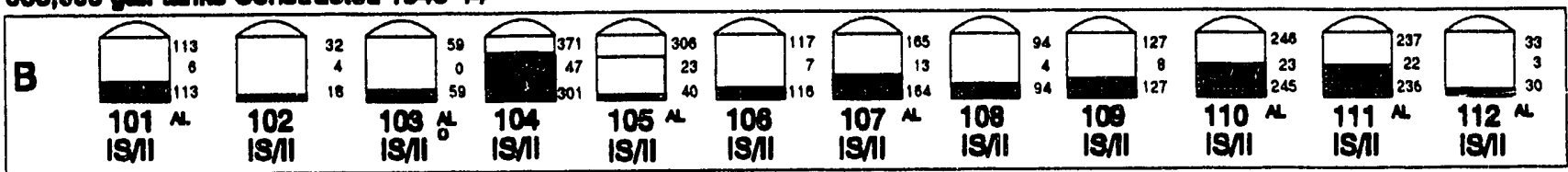

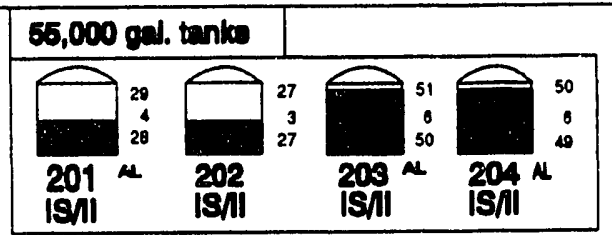

500,000 ool. tenke Conotrueted 1948-47

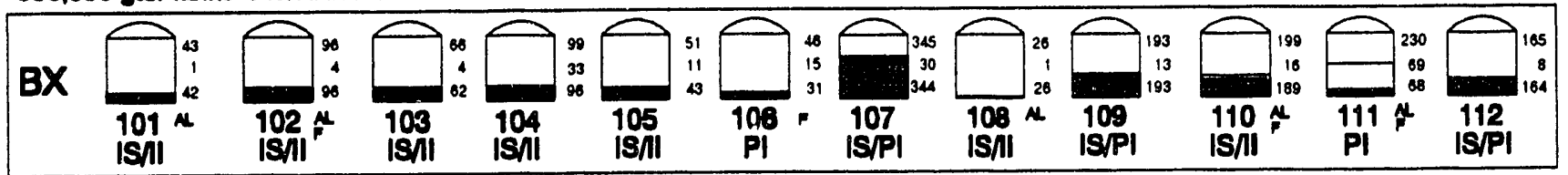

760,000 gal. tanks Constructed 1948-49

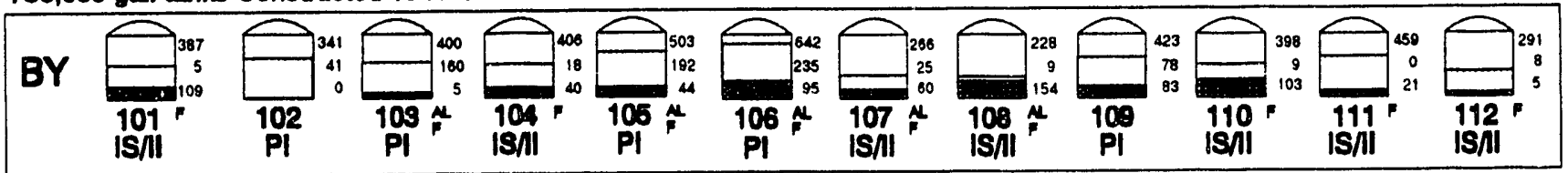

500,000 gal. tanka Conotructad 1849-44

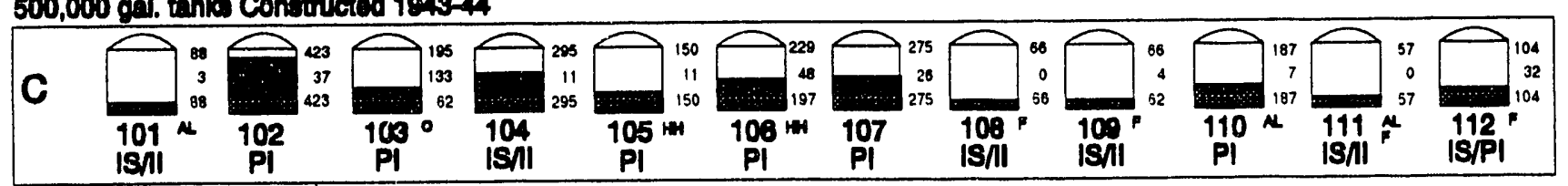

\begin{tabular}{|c|c|c|c|c|}
\hline \multicolumn{2}{|c|}{55,000 gal. tanks } & & & \\
\hline 0 & 2 & & $\longrightarrow$ & $\longrightarrow$ \\
\hline & & 0 & 0 & \\
\hline $\begin{array}{l}201 \\
|8 / 1|\end{array}$ & $\begin{array}{l}202 \\
18 / 1\end{array}$ & N. & $\begin{array}{l}203^{N} \\
|S|^{2}\end{array}$ & $\begin{array}{l}204 \\
|S /|\end{array}$ \\
\hline
\end{tabular}

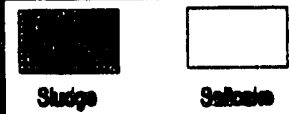

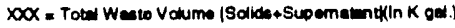

$x O X$ - Tow Iquide (in K gell.)

poranebio intwrseted + Supemaunt

$x O X=$ Sludeg (in K ger)

(Surceke Towe Not Shown)
M. - Manned Lem

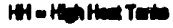

$F=$ Funsorits

iniosian

$0=$ Orimis

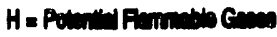

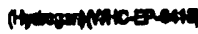

Updated Quarterty 03/31/93
II - Intorim Isoleted

IS - Interim Stobillzed

$P \mid=$ Pardaly Interim lsolated

STTHisa sfoncentos

Figure B-5. 200E Single-Shell Tank Status 
760,000 gel. tanis Construttad 1900-61

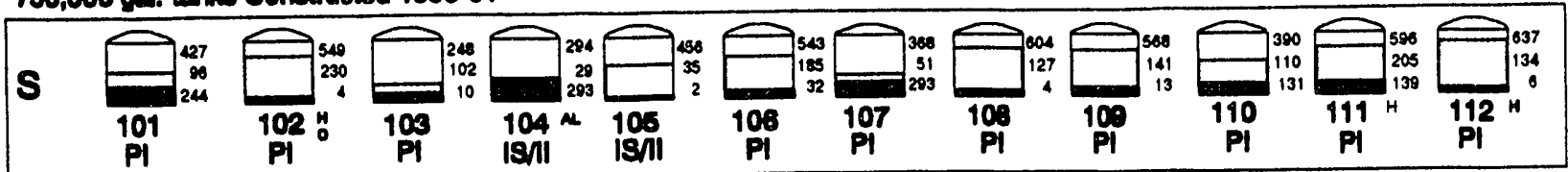

1,000,000 gal. tanien Conitructed 1903-64

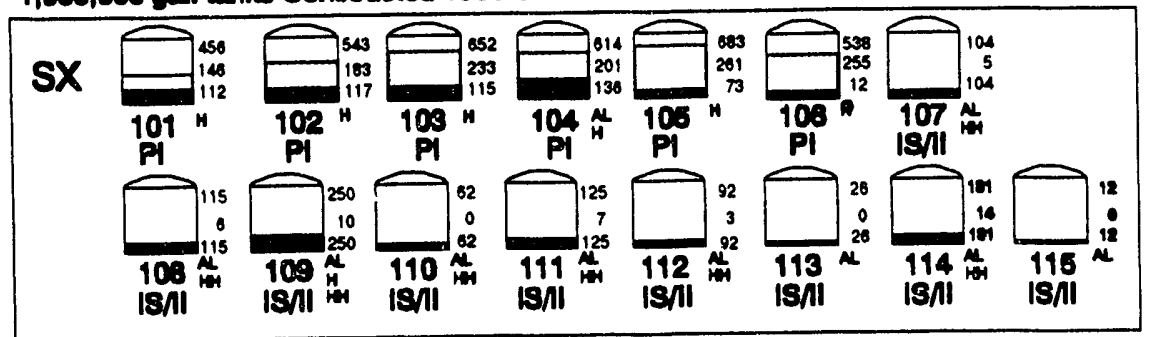

500,000 ad. tentio Constructied $1948-44$

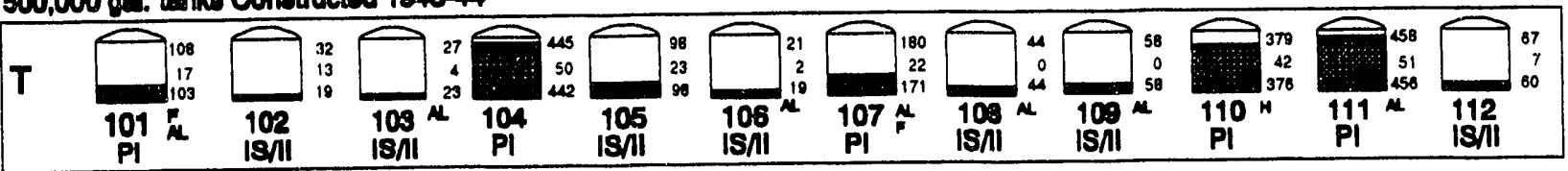

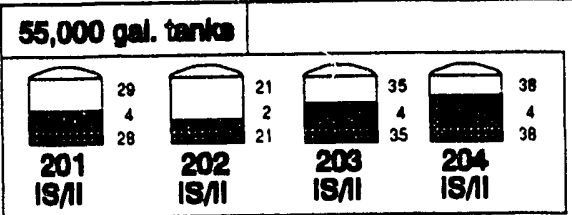

750,000 gel. tanka Conetructed 1047-48

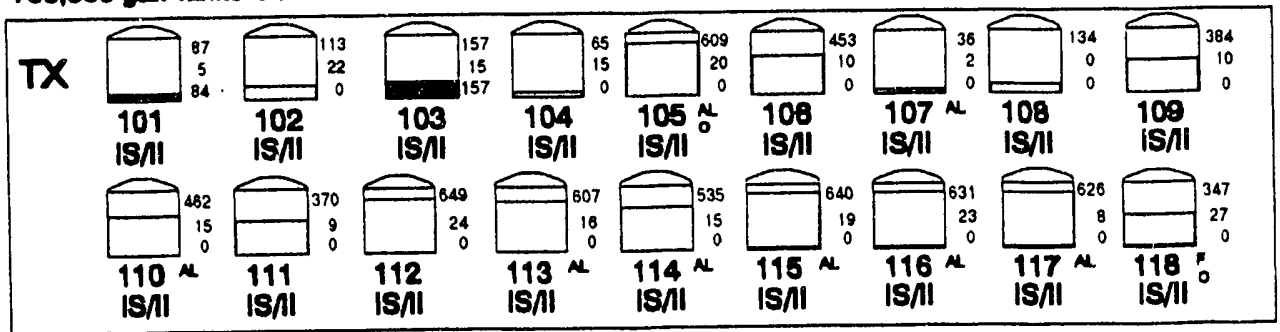

760,000 gal. tenks Constructed $1951-62$

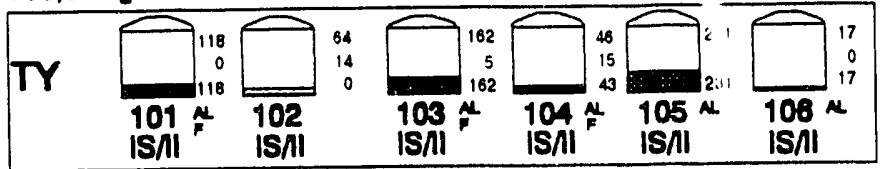

$500,000 \mathrm{gcl}$. tenke Conotructed $1840-44$

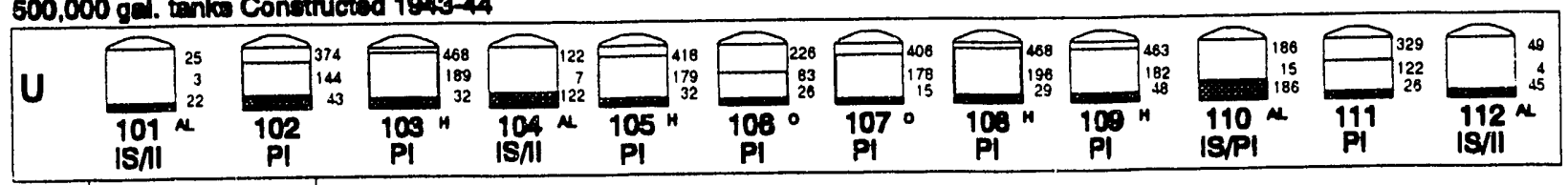

55,000 gal. tanks

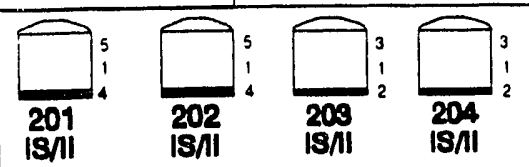

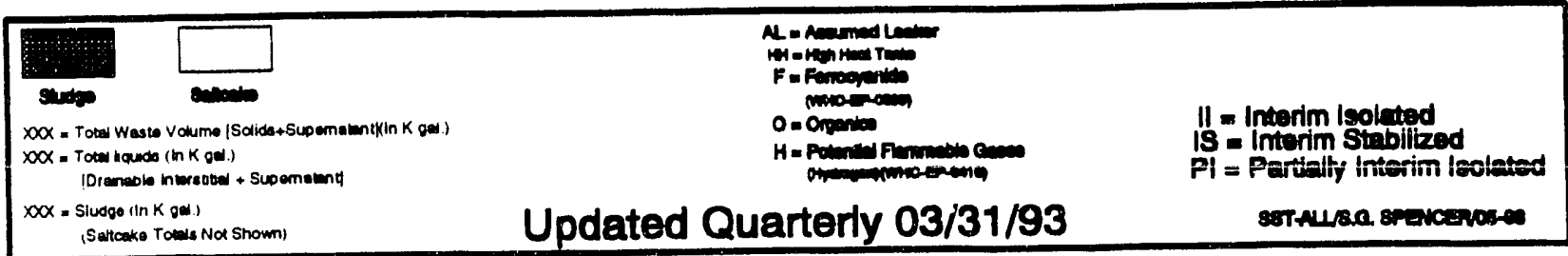

Fig. B-6. 200W Single-Shell Tank Status 


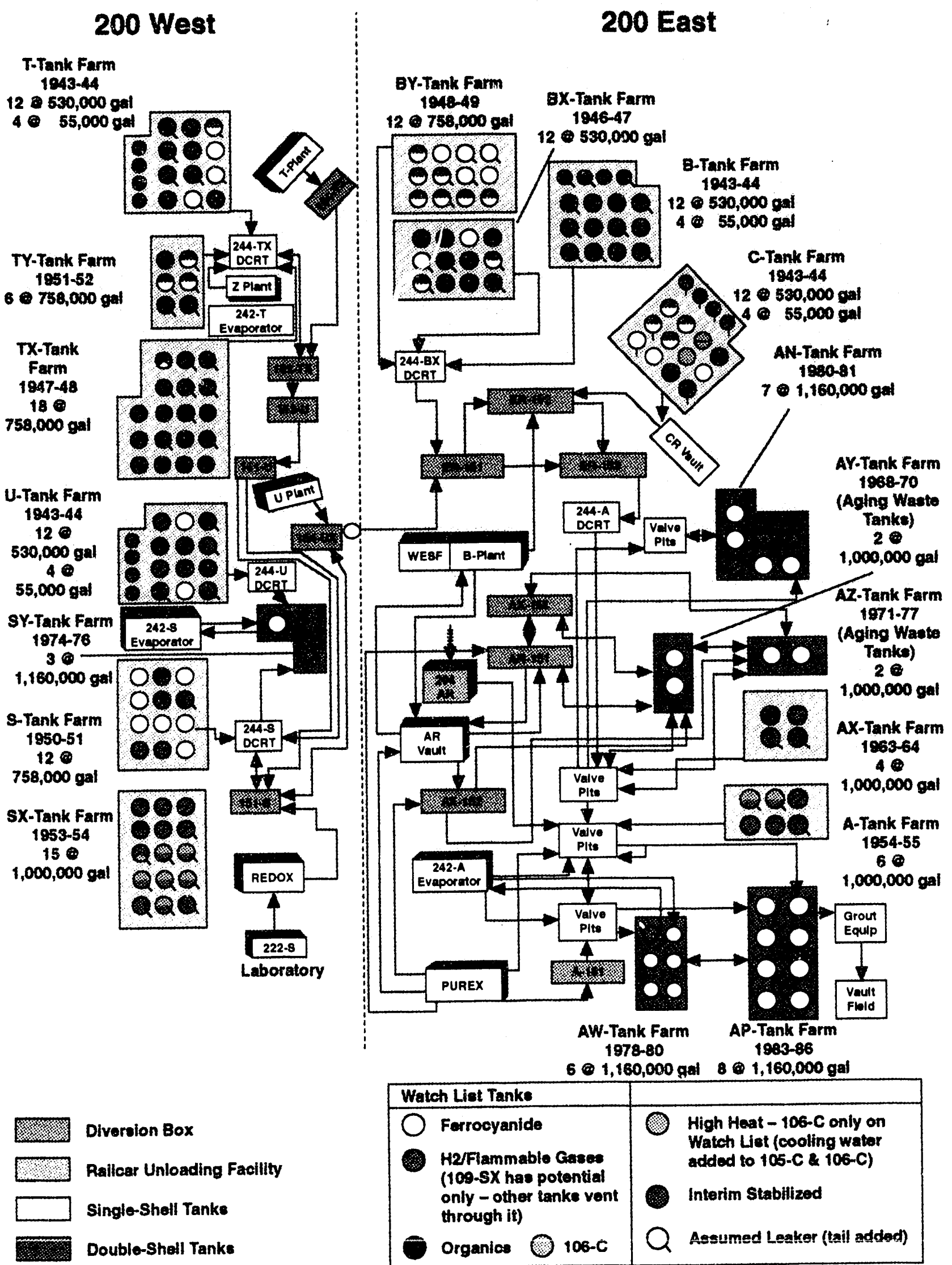

Figure B-7. Tank Farm Facilities - Quick Reference 


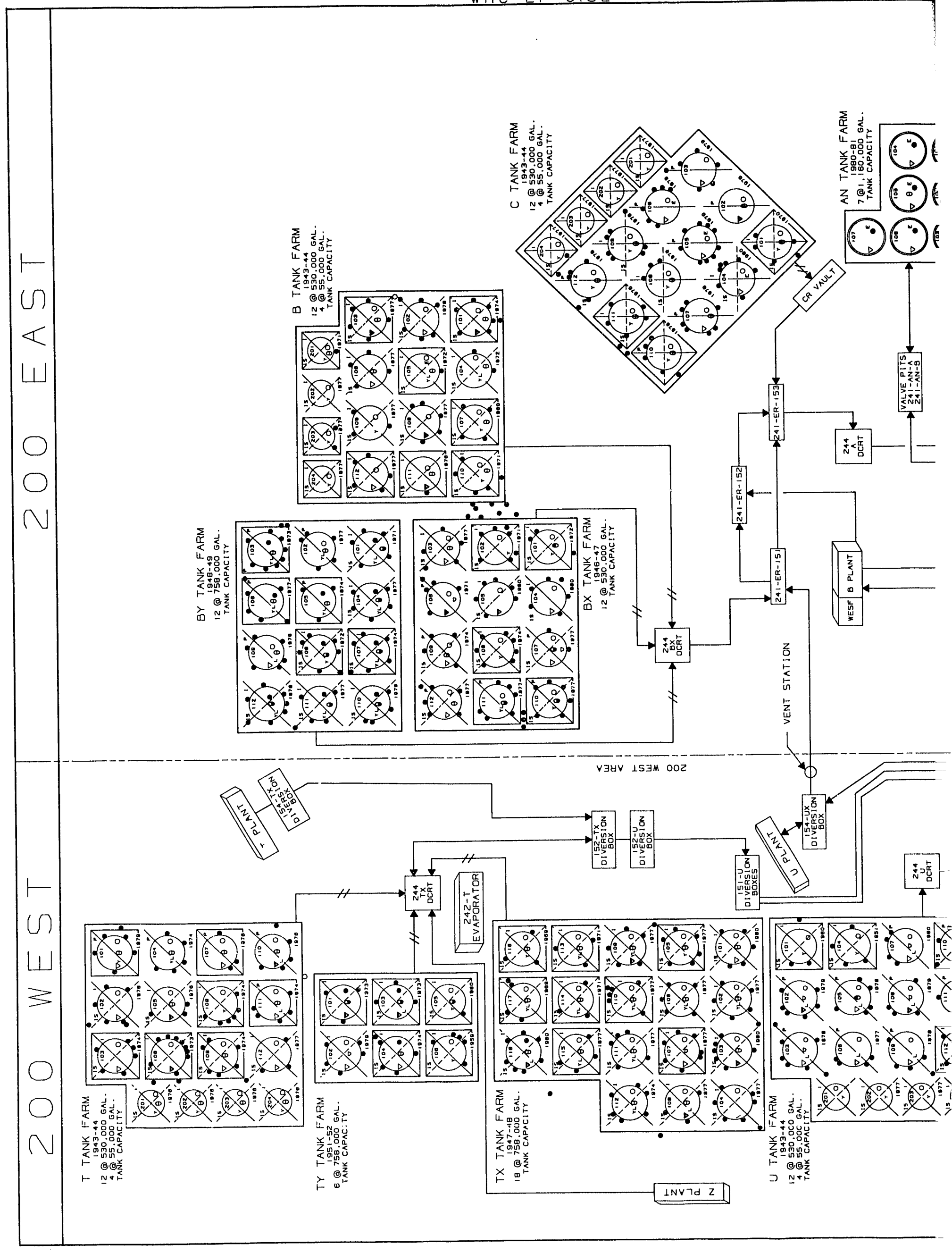




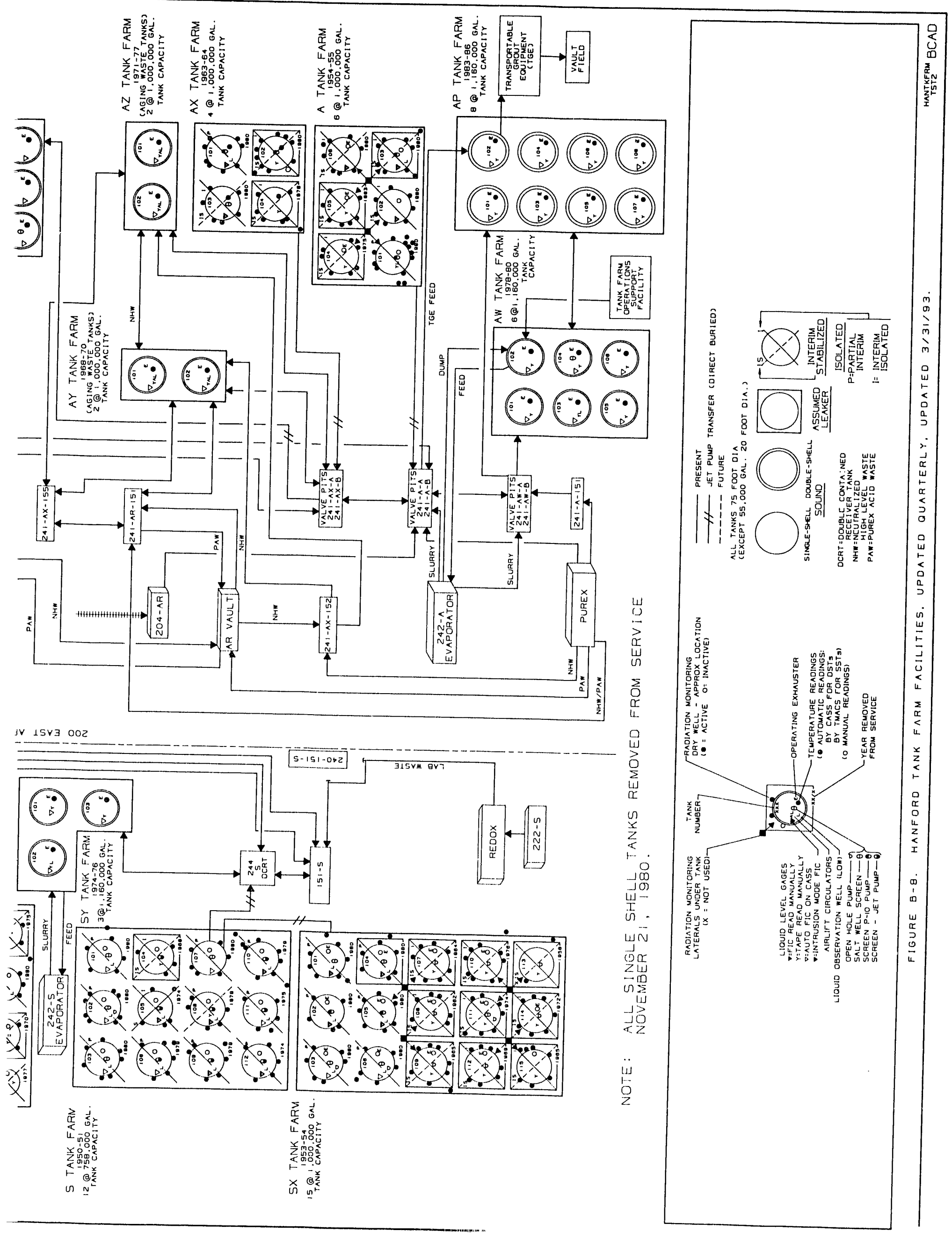


WHC-EP-0182-61

\section{APPENDIX C}

\section{MONTHLY SUMMARY}

TANK USE SUMMARY

INVENTORY SUMMARY BY TANK FARM

INVENTORY AND STATUS BY TANK 
WHC-EP-0182-61

This page intentionally left blank.

-

C-2 
WHC-EP-0182-61

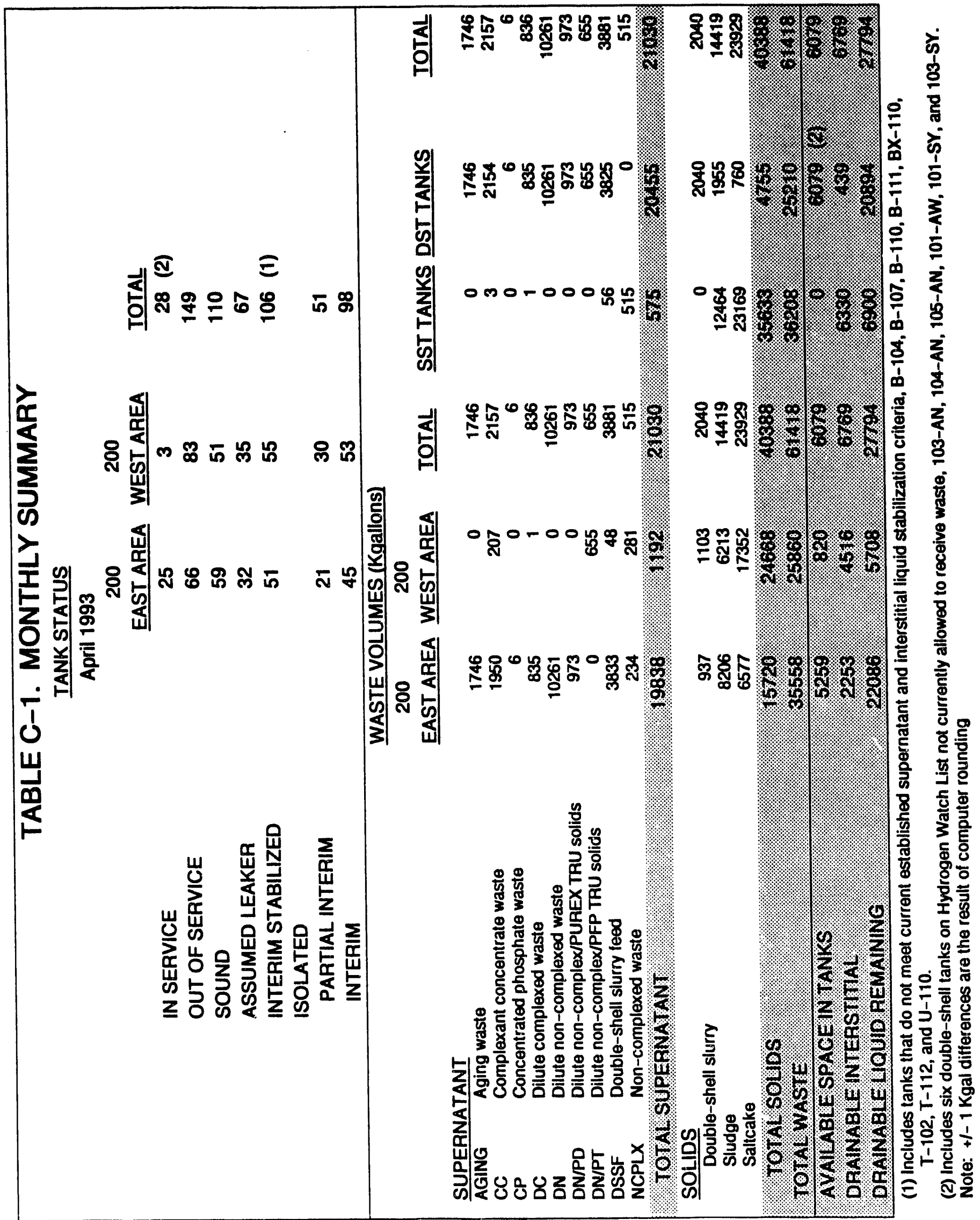


WHC-EP-0182-61

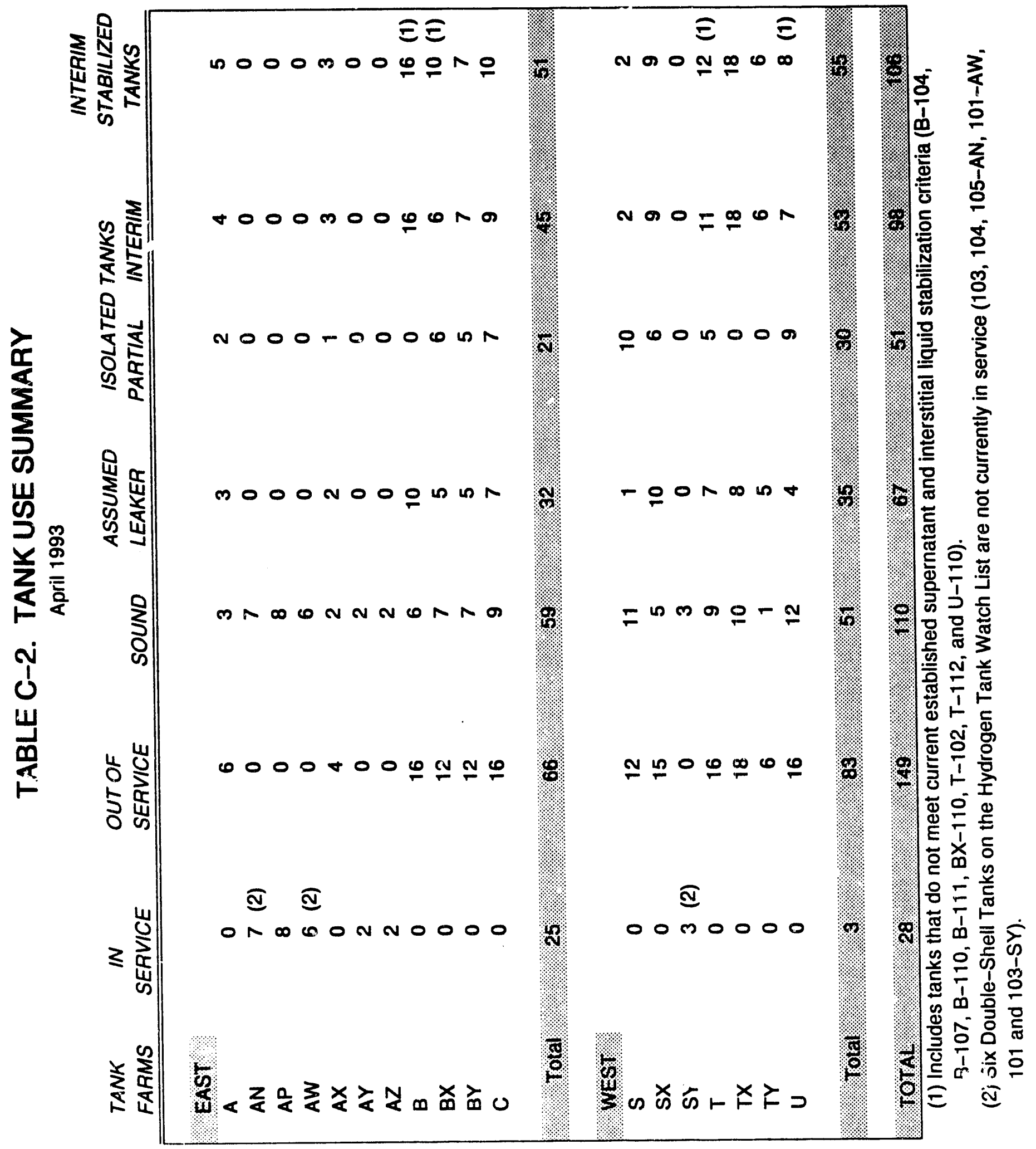


WHC-EP-0182-61

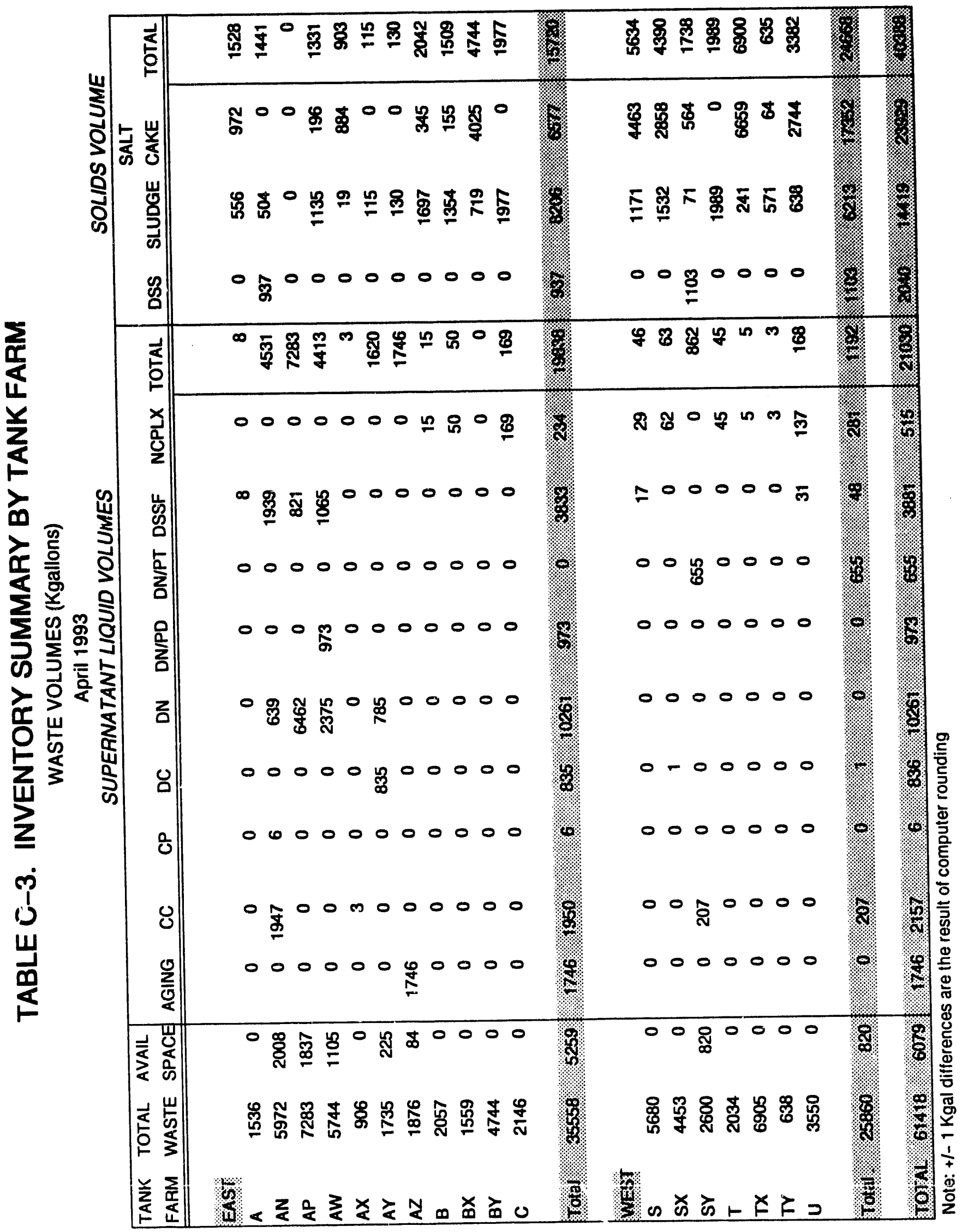




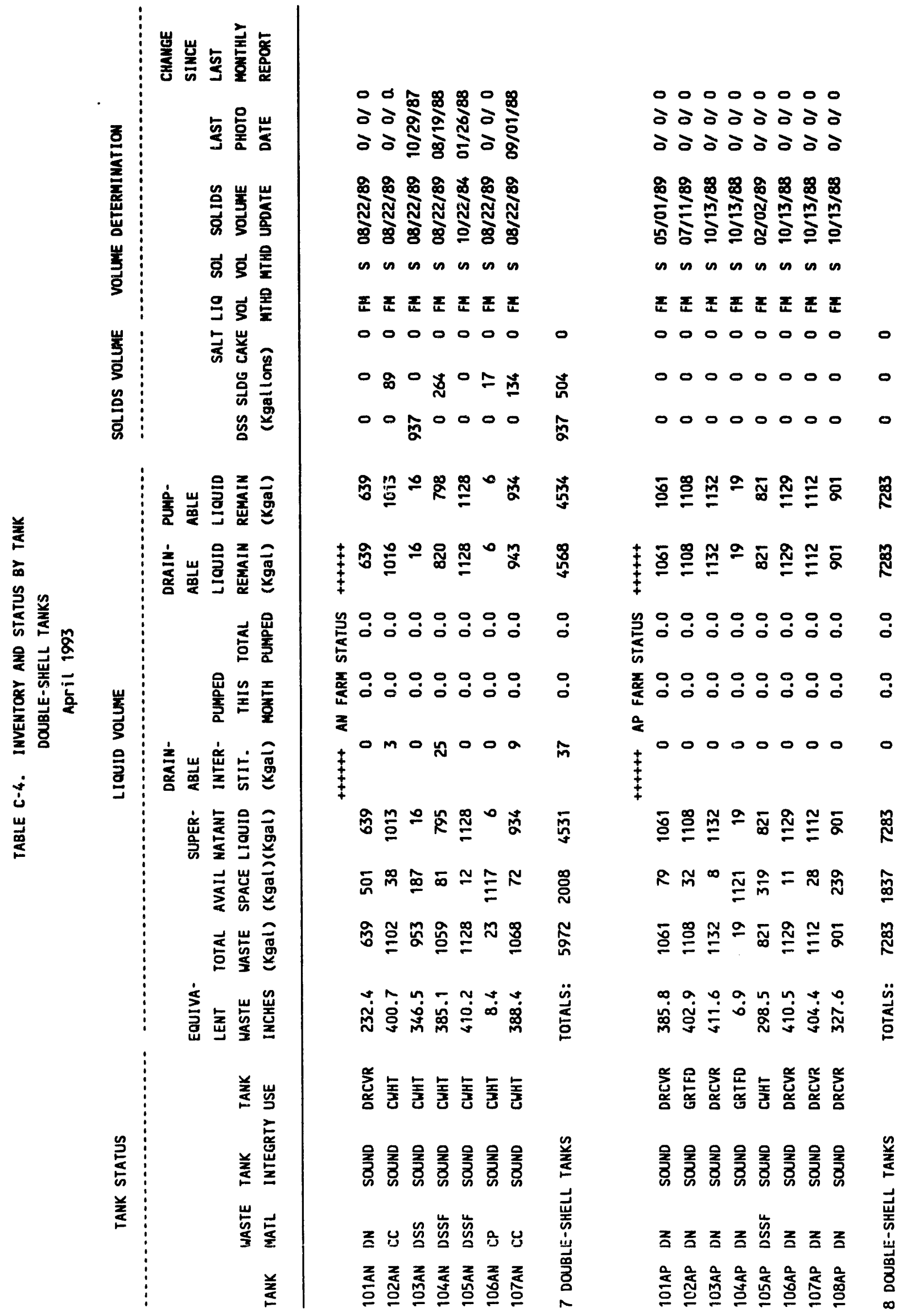




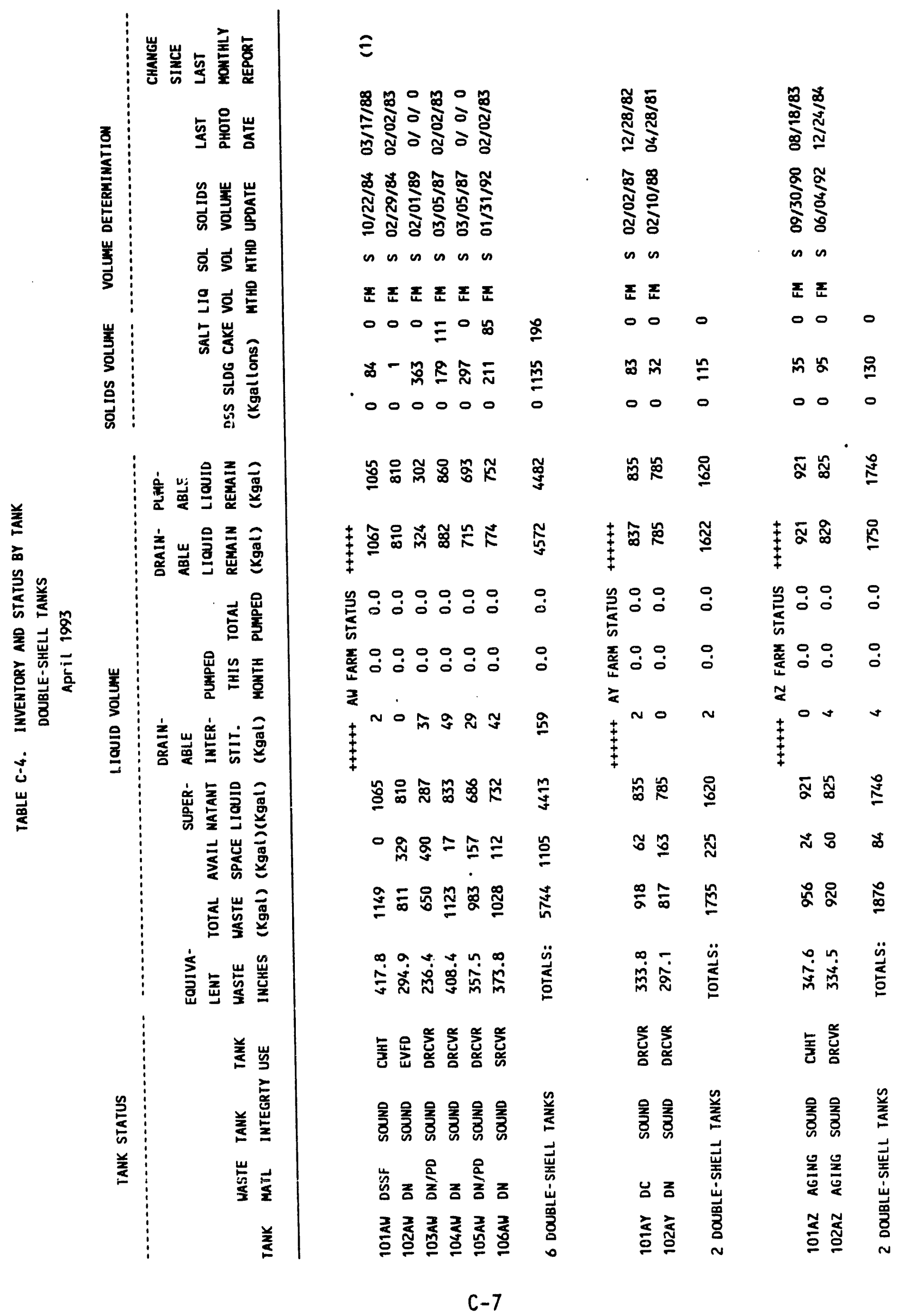


差

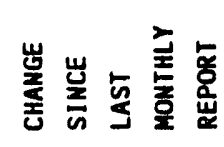

줄

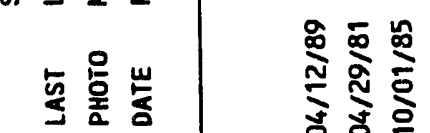
웡 응

:

苔崖崖

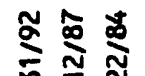

กับ ำ ำ

항 훌

an os

옹 울

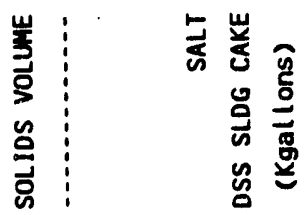

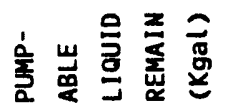

高

蛋善

完寻

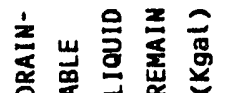

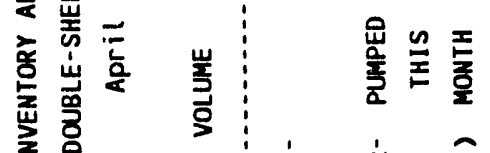

苍裘

준 푼

号口ง 施

0 此

융 상

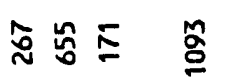

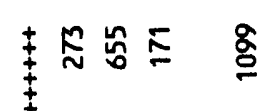

$\mid$

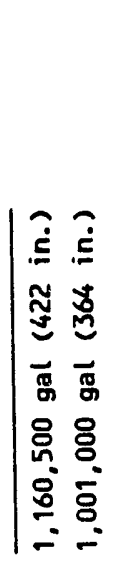

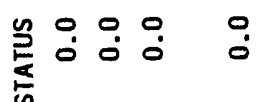

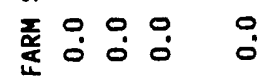

产谙崖言言

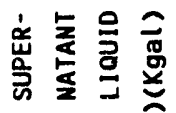

崖哥

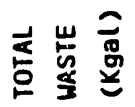

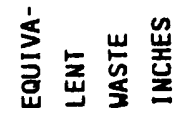

它

\section{के \\ + ñ o n}

客

圭等

กำ ผูำ ัั

$\pm \frac{\widetilde{m}}{\sigma}$

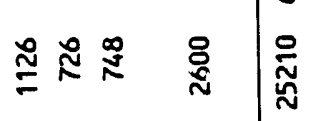

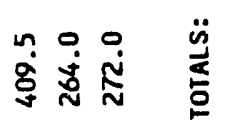

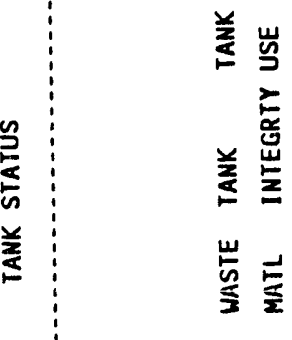

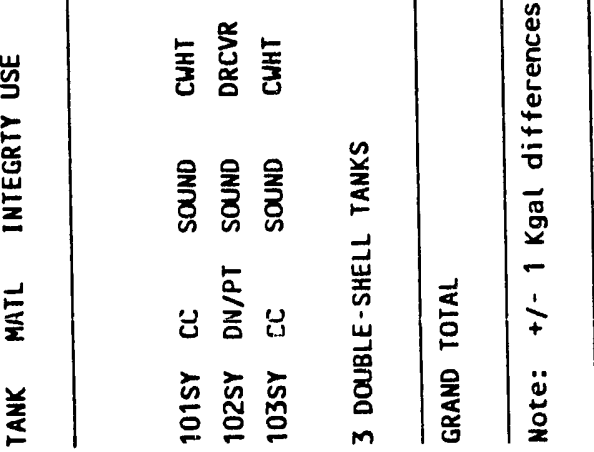

晏

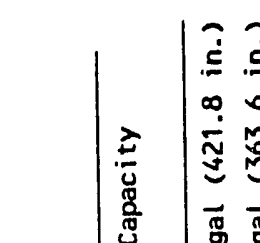

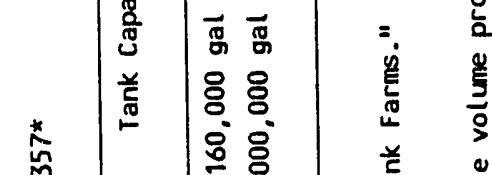

萃

旁

荋

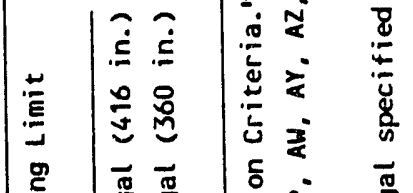

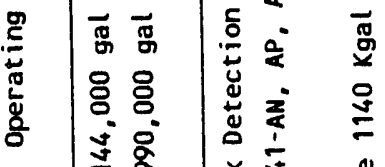

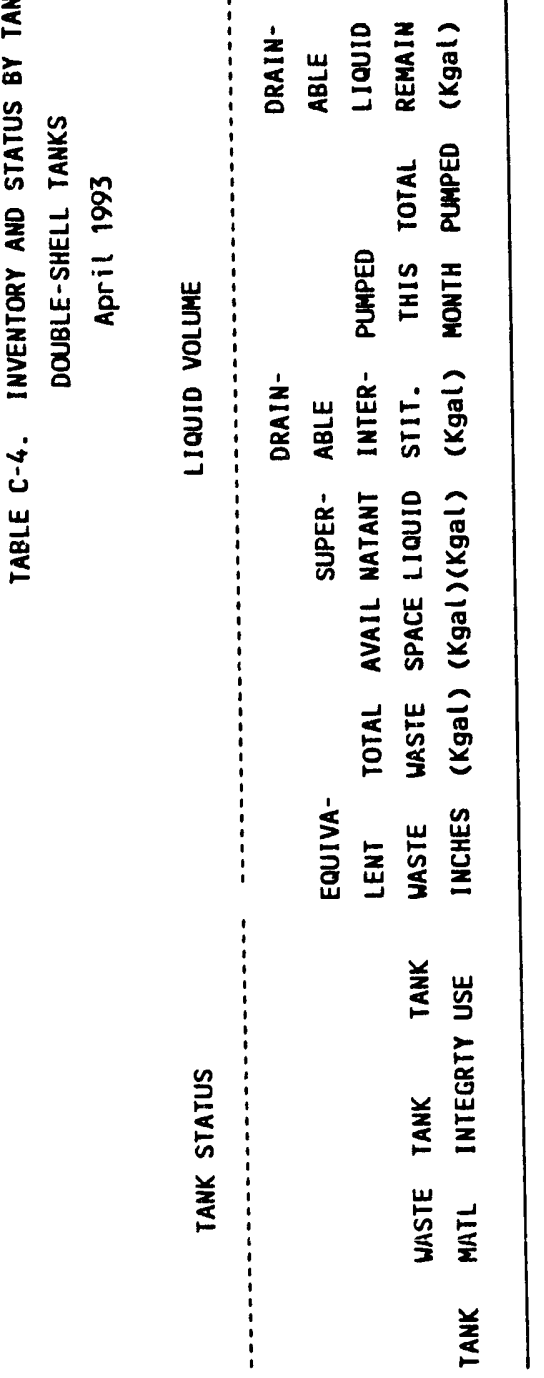

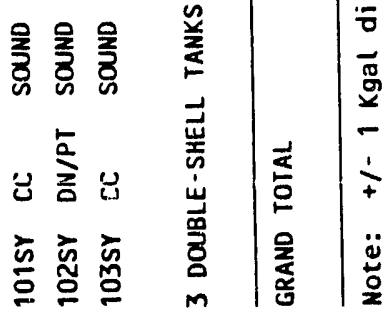

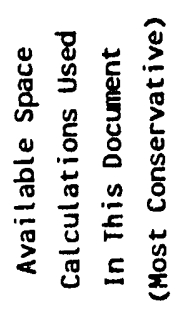

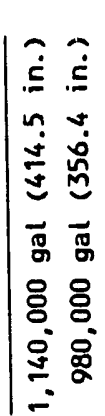

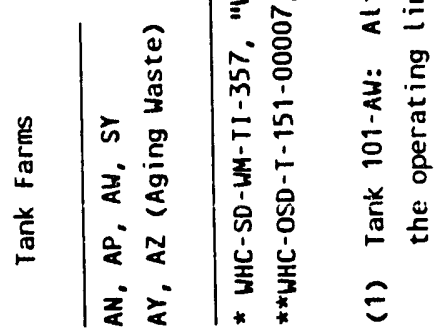




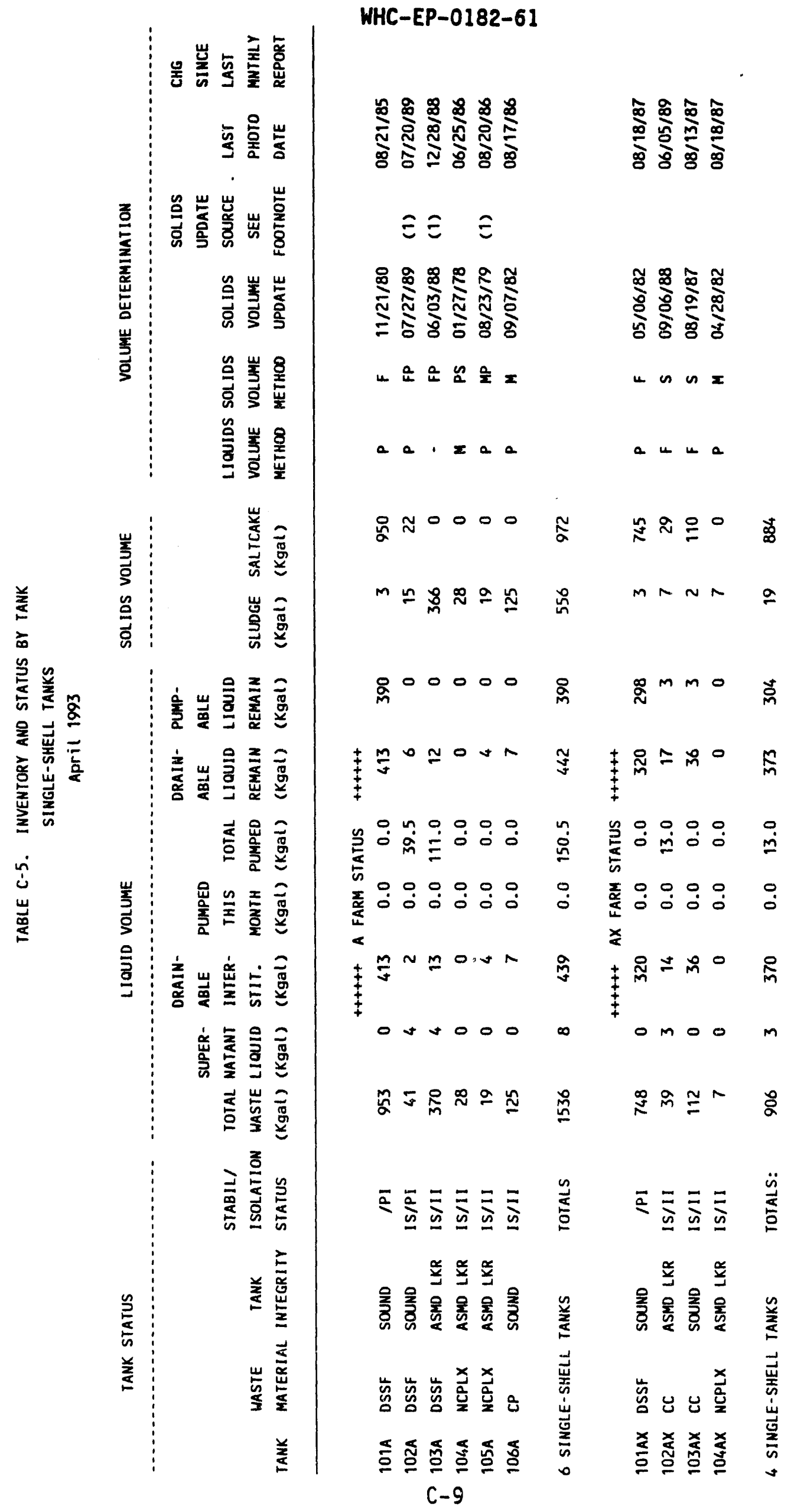




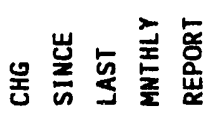

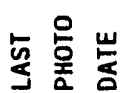

즘

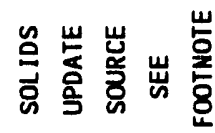

苍崖崖

뜽 똫 울

항 홀

崖

啚

高

襇

울 경

言恧

密 볼

ن́

岕 葋

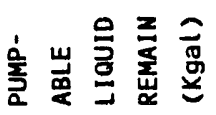

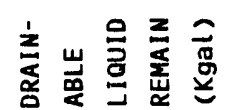

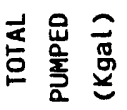

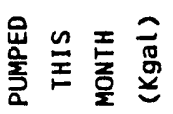

蒙崖

WHC-EP-0182-61

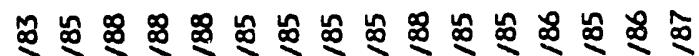

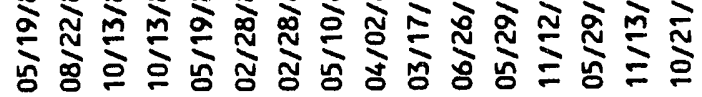

ミミミミミミミミミミミミミ

๓

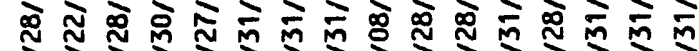

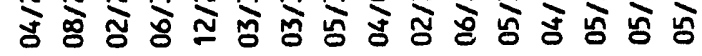

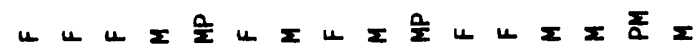

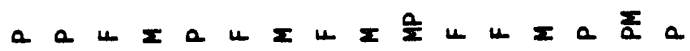

000 每00000000000 先

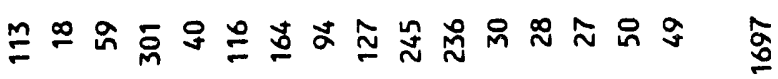

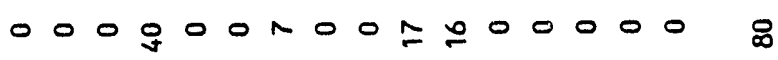

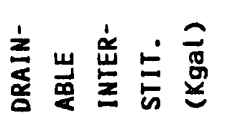

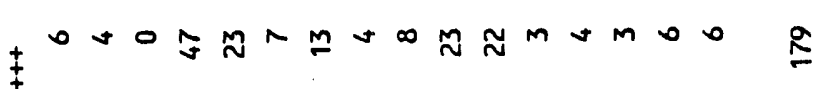
$\pm$

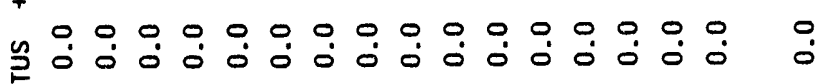
岳

焉

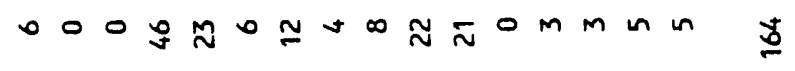

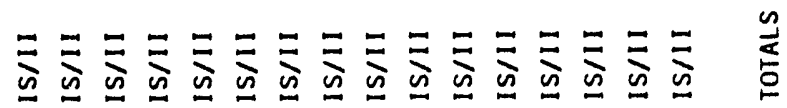

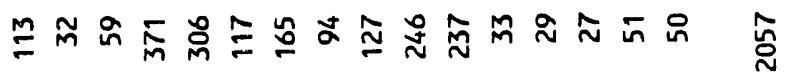

美总

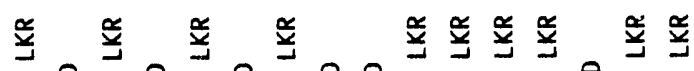

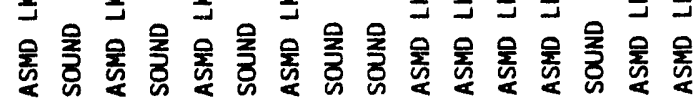

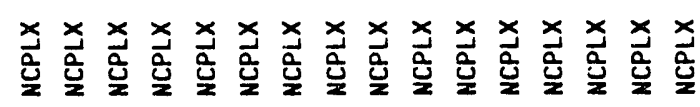

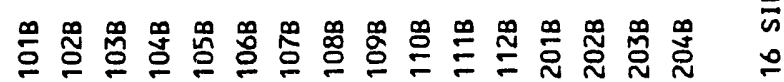




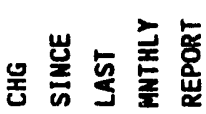

产䝑崖

중

美

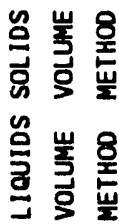

崖票

崖

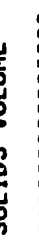

崖
WHC-EP-0182-61

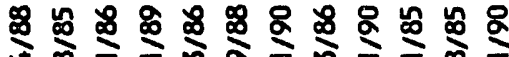

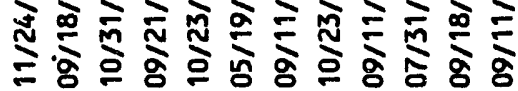

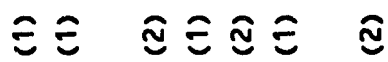

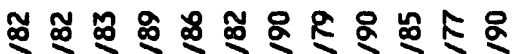

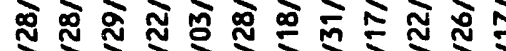

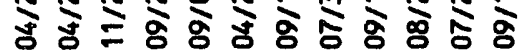

岩 蛋

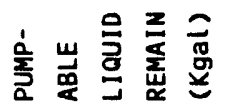

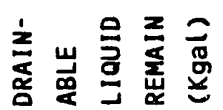

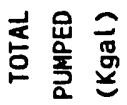

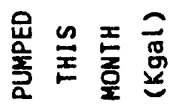

咅

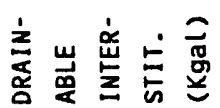

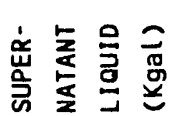

岕耑票

总

萦总

蛋

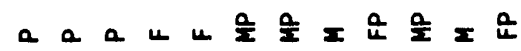

$0000 \mathrm{mo0} 000 \mathrm{mo}$

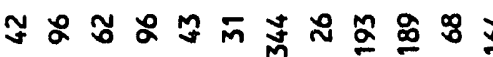

0 0 0 กง

希

+
$\vdots$
$\vdots$
$\vdots$

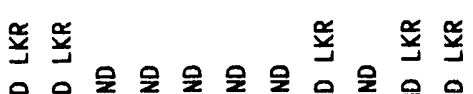

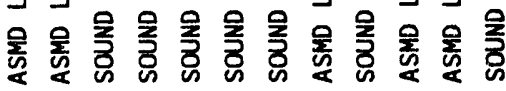

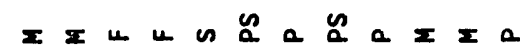

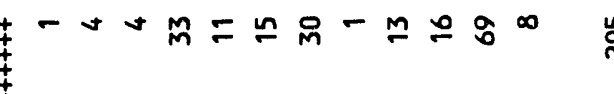

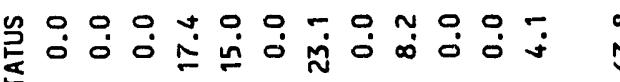

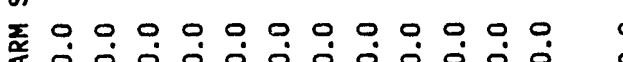

이일

- O v m nn n- $00-2-$

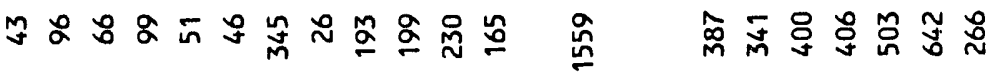

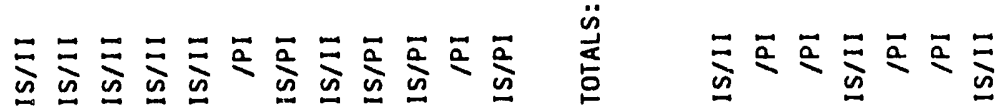

离突

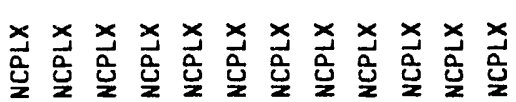

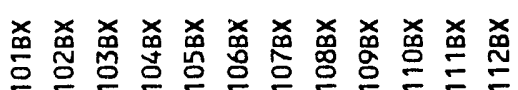
C-11

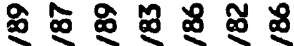

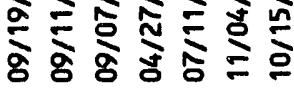

ิิ ิิ

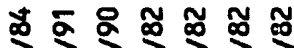

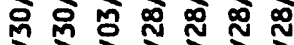

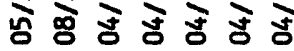

I $x=\frac{0}{2} \frac{0}{2} \frac{0}{2}$

a 올 올 a a a

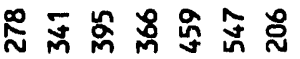

gㅇํ의 영

$0 \approx \underline{\mathrm{m}} 0 \stackrel{\mathrm{g}}{\mathrm{N}} \mathrm{O}$

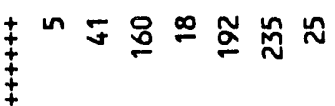

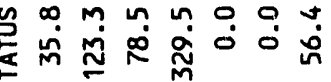

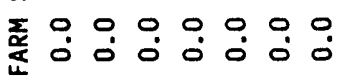
के

0000000

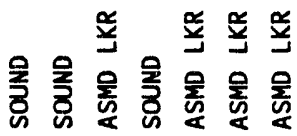

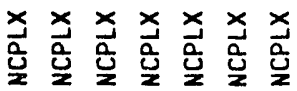

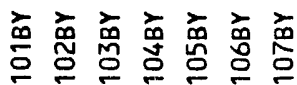

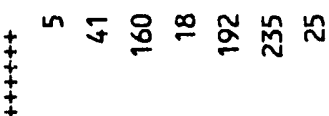




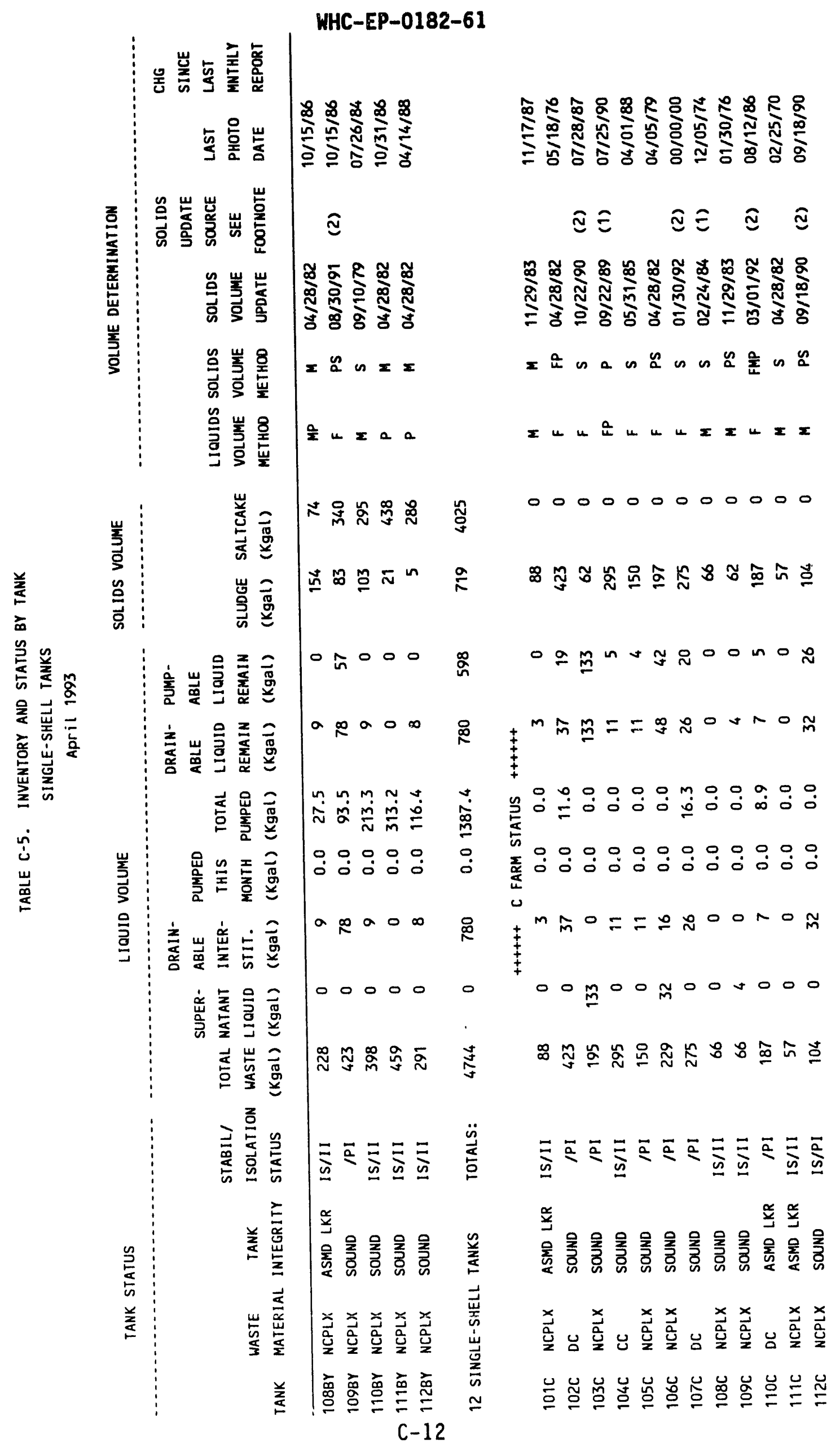




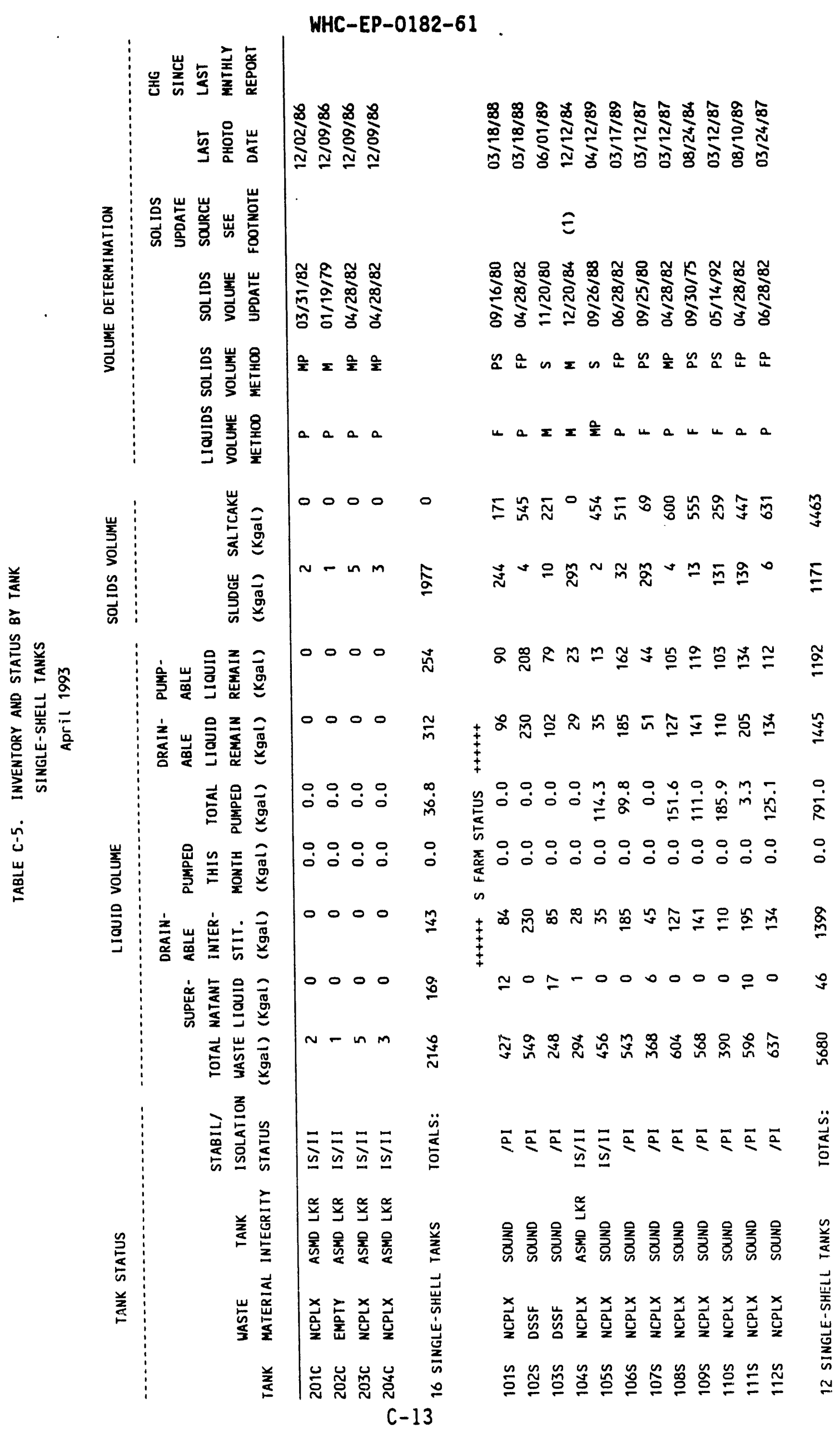




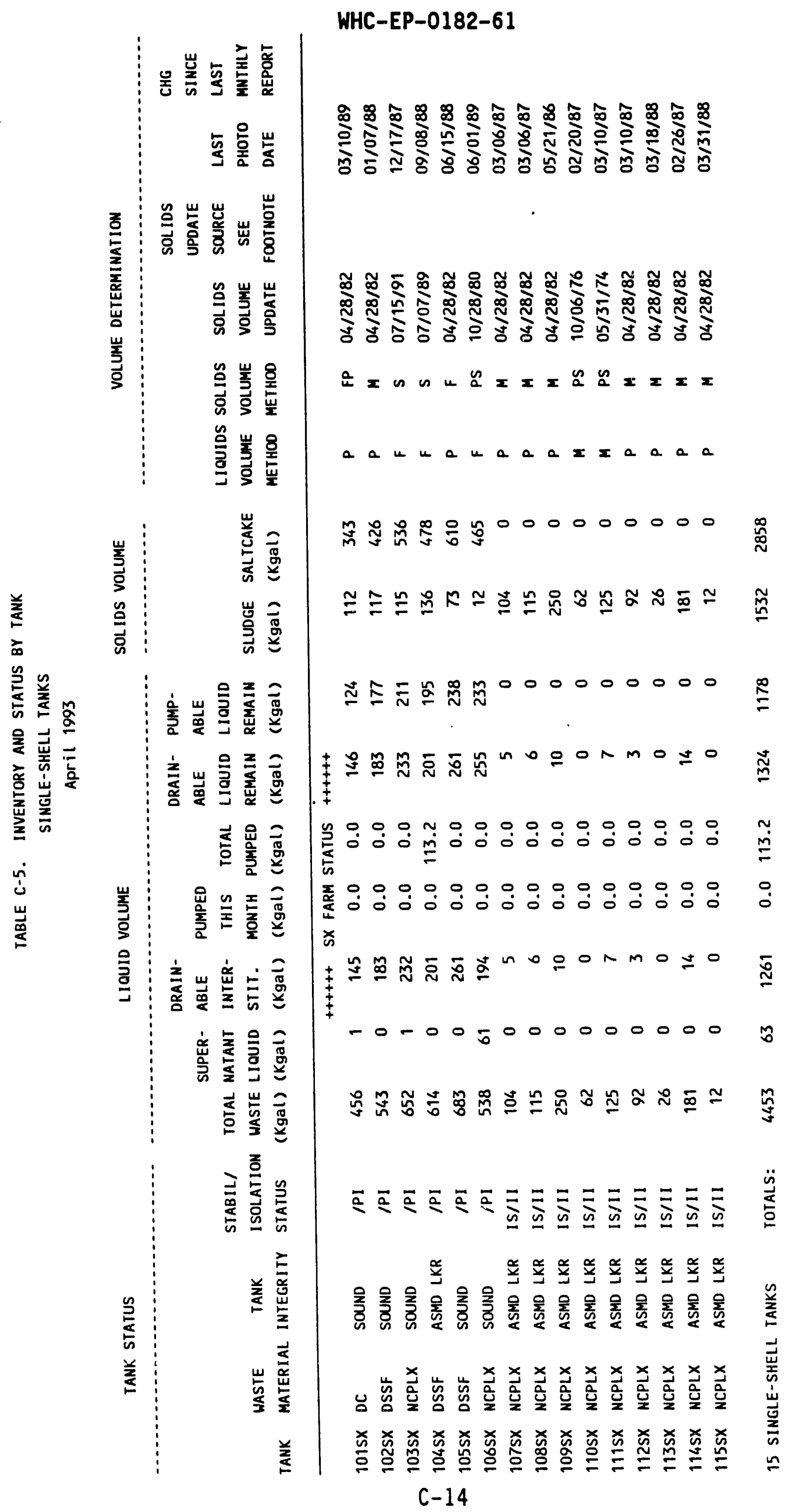




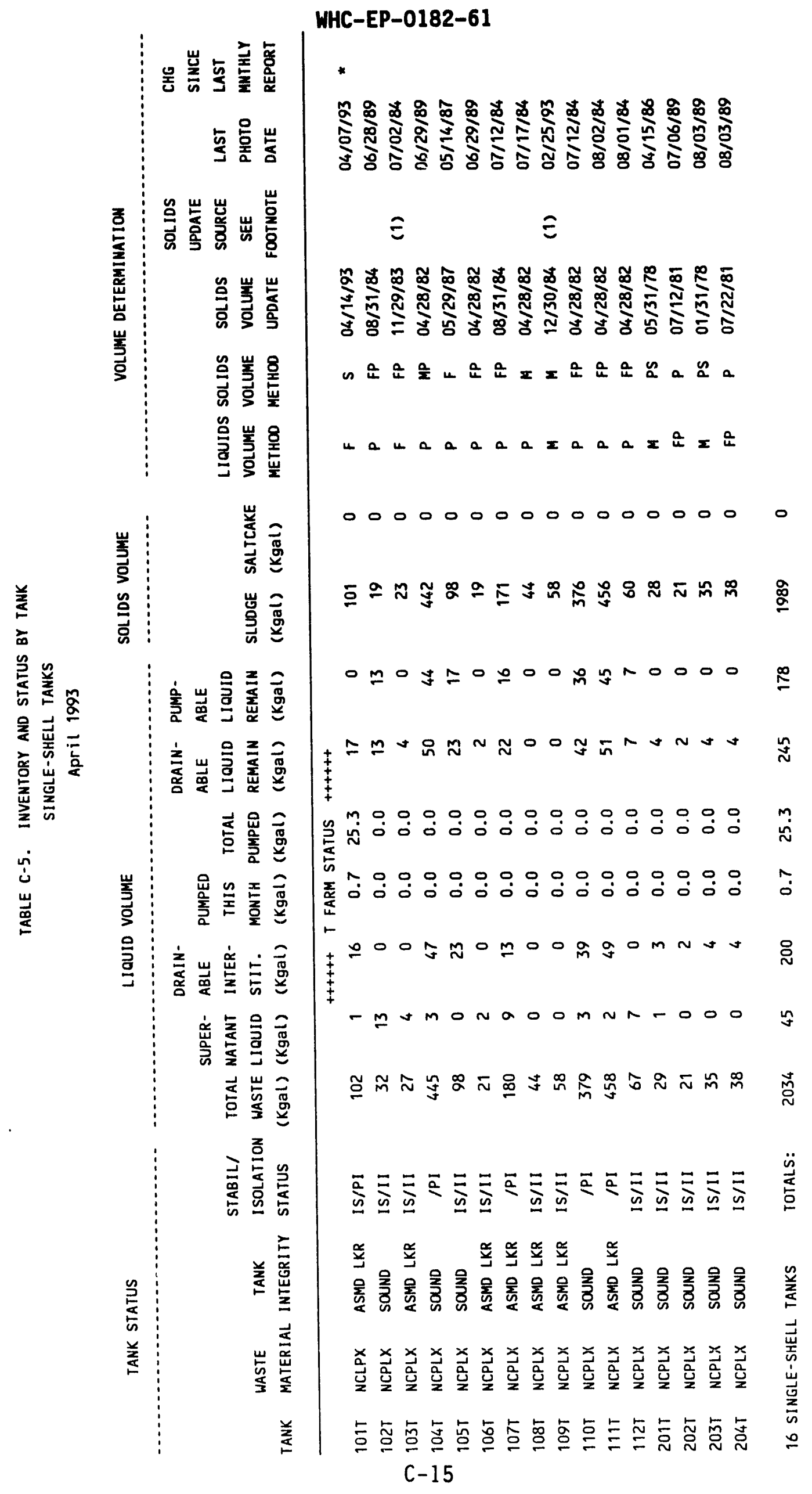




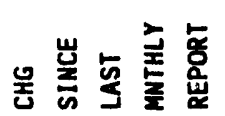

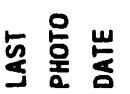

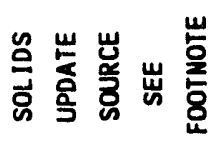

哭 崖

음 눌

硈 点

号崖 울

崖点

养

嵌 恋

点点焉

윴 嶎

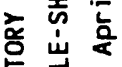

政需

in

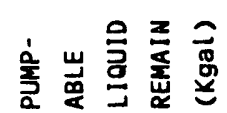

立

在 蒙

崖

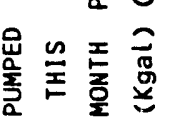

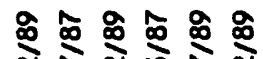

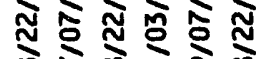

总吉总

$=$

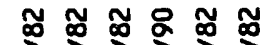

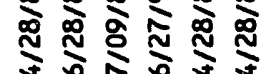

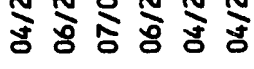

는은 운 운 $x$ I

a a a a a

0 H 000007

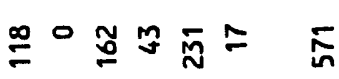

을

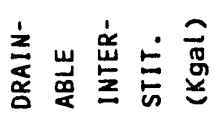

0000000

$\pm 0 \pm n n 00 \quad m$

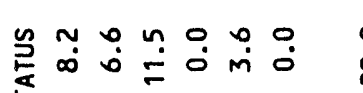

$z$

tovin no

离㲤言高

紊岕

总焉罢

总总

$\stackrel{n}{a}$

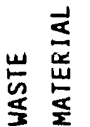

辰

出

紊

京

$000 \mathrm{~mol}$

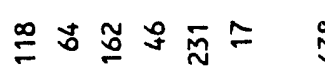

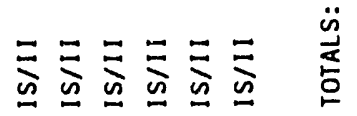

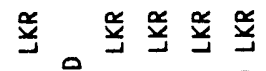

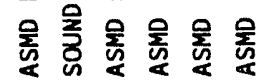

皮

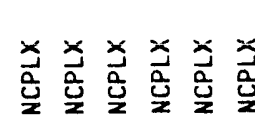

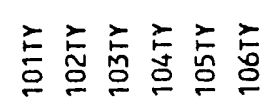

C -16

岁总

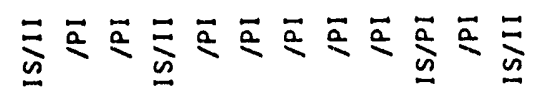

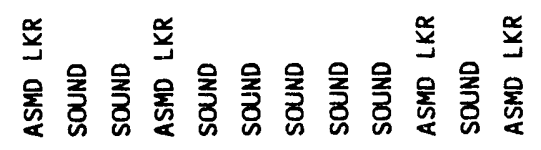

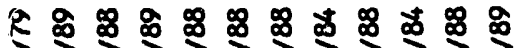

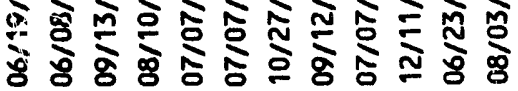

$\Xi £$

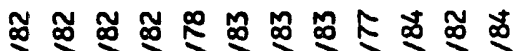

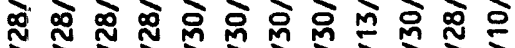

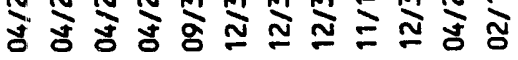

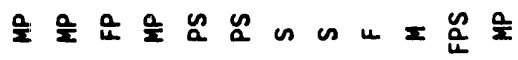

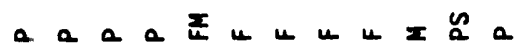

○ $\frac{m}{m} \underset{\sim}{~}$

กิ

○ ㅇํำ

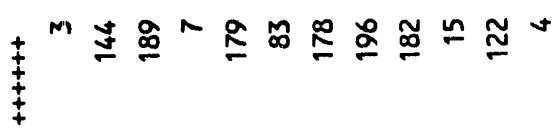

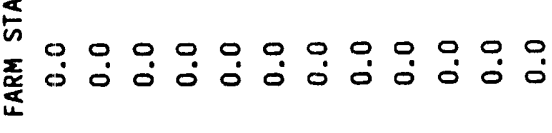

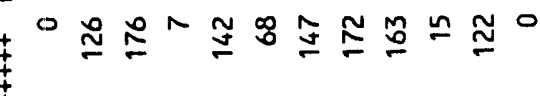

n $\infty$ mon

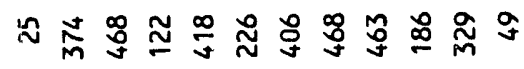

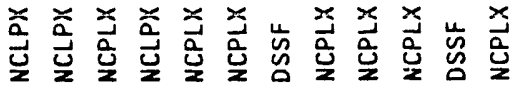

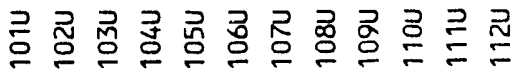




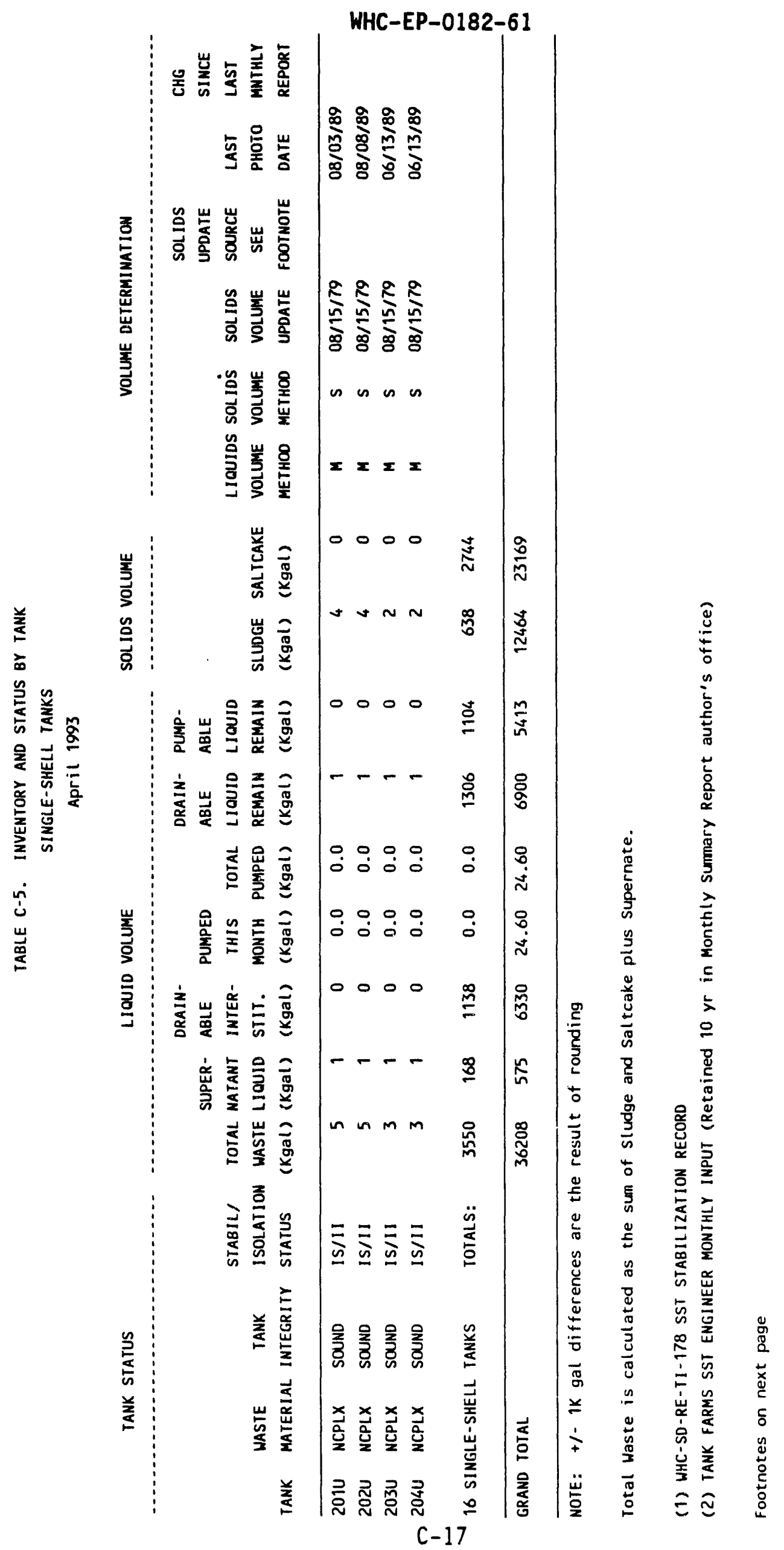


WHC-EP-0182-61

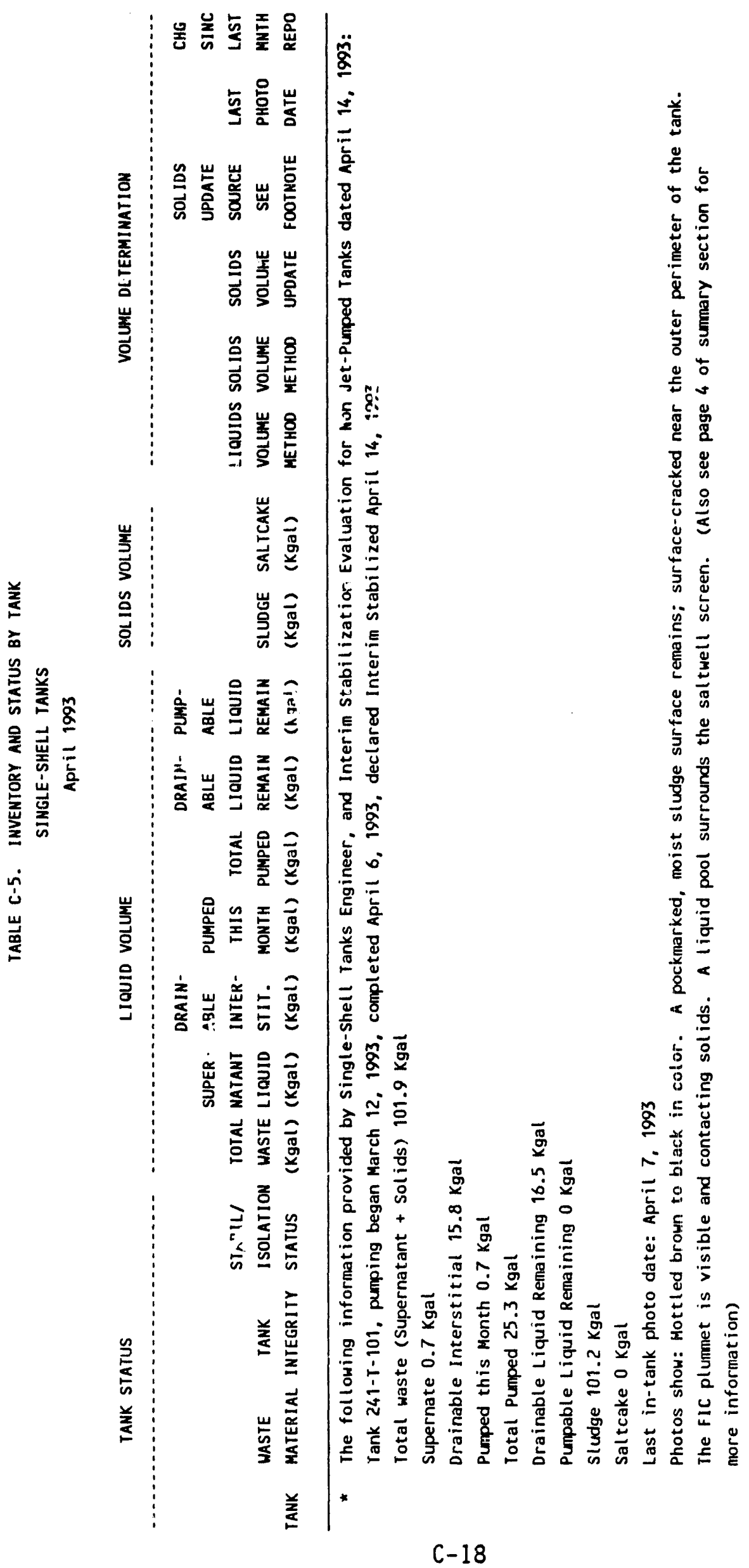


WHC-EP-0182-61

APPENDIX D

\section{PERFORMANCE SUMMARY}


WHC-EP-0182-61

This page intentionally left blank. 


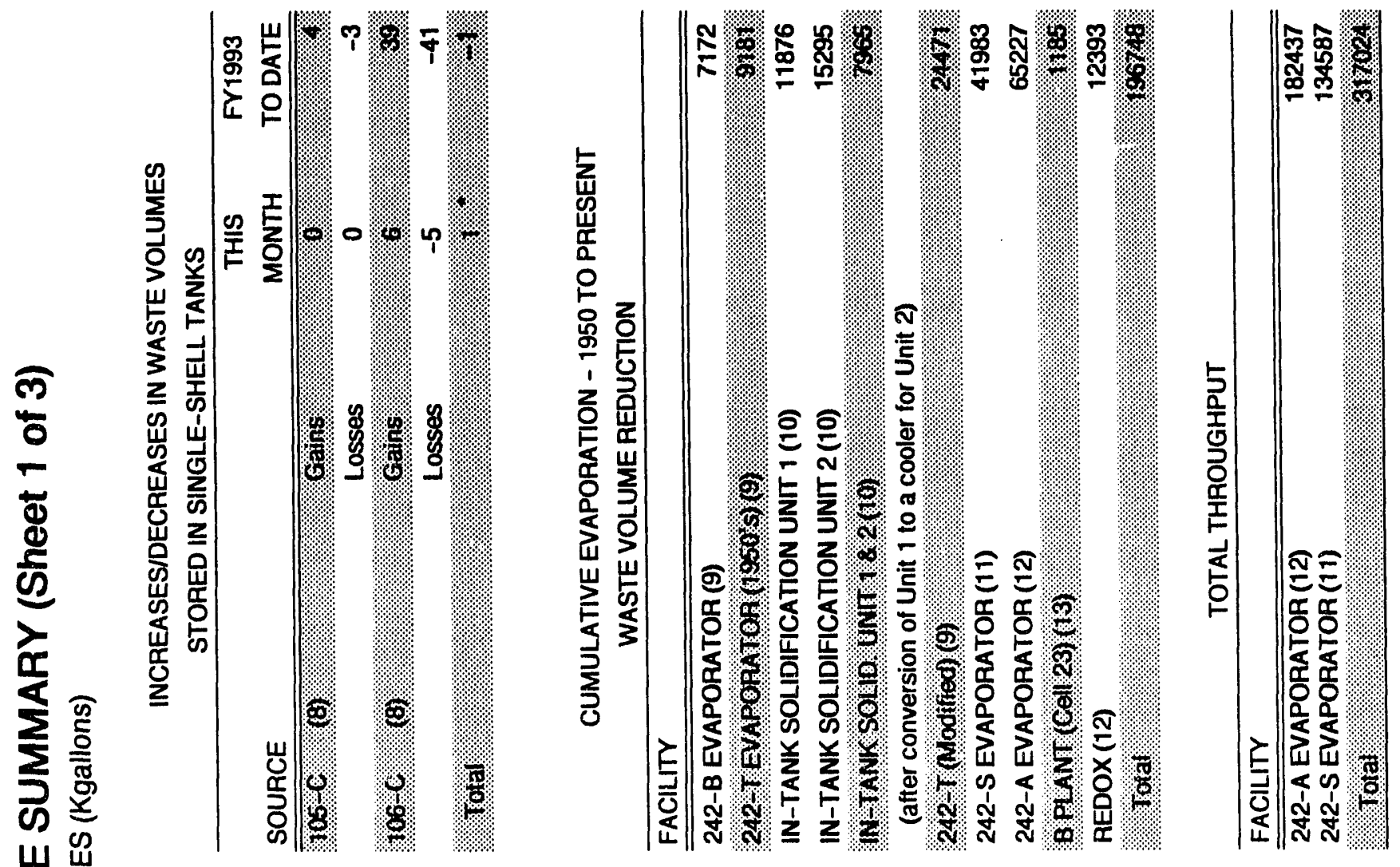

剀

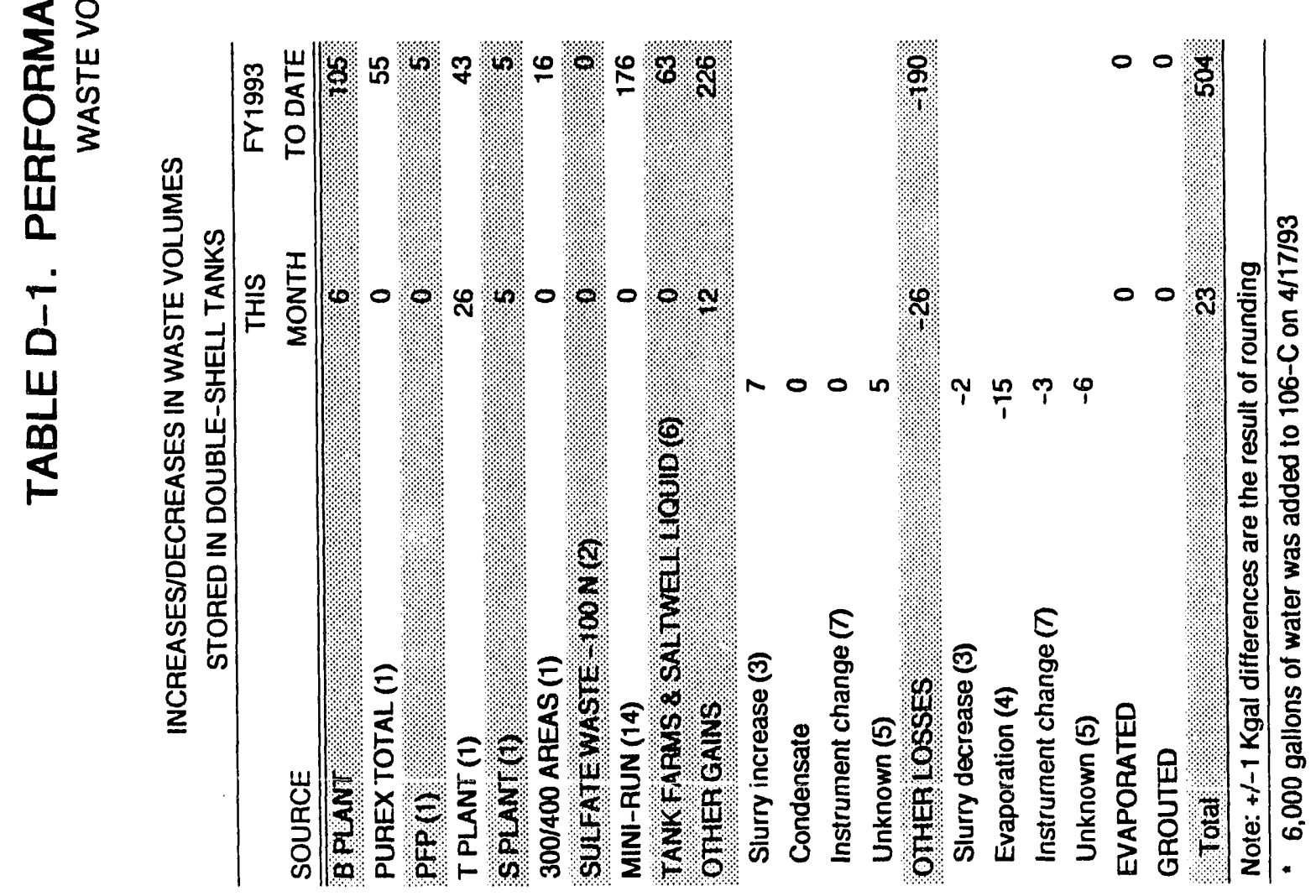

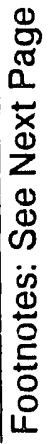


WHC-EP-0182-61

TABLE D-1. Performance Summary (Sheet 2 of 3 )

Footnotes:

\section{INCREASES/DECREASES IN WASTE VOLUMES}

(1) Including Flush

(2) Sulfate waste is generated from ion exchange backflushing and sand filter clean out, resulting in sulfate waste $\left(\mathrm{Na}_{2} \mathrm{SO}_{4}\right)$.

(3) Slurry increase/growth is caused by gas generation within the waste. The gas which is trapped in the waste expands in the tank causing the surface level and volume to increase. Slurry decrease results from the periodic release of gas in the waste.

(4) Aging waste tanks

(5) Unknown waste gains or losses may be the result of rounding calculations, clean water slowly leaking through a valve, changes in levels (expansion/contraction) because of ambient temperature changes, different measuring devices being used by Tank Farm operators, transfers taking place during the end of the month, Tank Farm activities such as miscellaneous water additions not associated with facility waste generation, or the addition of water which is added to aging waste tanks and then evaporated off.

(6) Includes Tank Farms miscellaneous flushes (flushes are used to "clean out" pipelines and reduce personnel exposure, reduce potential for waste incompatibility, prevent line plugging, and reduce waste content of potential spilis or leaks), and saltwell liquid, which results from pumping of single-shell tanks to double-shell tanks.

(7) Liquid level measurement instrument changes from the automatic FIC to manual tape (and vice versa) result in unusual gains or losses because the manual tape may rest on an uneven crust surface giving a different reading from that of the automatic FIC. These instrument changes are made when the automatic FIC is out of service and the reading from the manual tape is used for reporting purposes. The reported reading reverts back to the automatic FIC when it is repaired.

(8) Water is periodically added to $105-\mathrm{C}$ and 106-C to provide evaporative cooling. Losses due to evaporation are calculated assuming all losses are evaporative losses. Drywell monitoring for leak detection is done monthly on tank 105-C. Some drywells are monitored weekly and some are monitored every two weeks on tank 106-C. If there are any indications of a leak from these tanks, the assumption that all losses are due to evaporation will be reevaluated. 
TABLE D-1. Performance Summary (Sheet 3 of 3 )

\section{WASTE VOLUME REDUCTION}

(9) Currently inoperative. These evaporator systems (242-B and 242-T) were installed in 1952 in each of the two operating areas to remove water from the waste, and ran for approximately 4 yr after which both units were shut down. The 242-T Evaporator was reactivated in December 1965 , and shut down again in April 1976.

(10) Currently inoperative. These two in-tank solidification (ITS) units provided in-tank heating to promote in-tank boiling or evaporation. The ITS Unit 1 started up March 1965, and ITS Unit 2 started up February 1968. In August 1971, ITS Unit 1 was converted from an evaporator to a cooler for ITS Unit 2. Both units were shut down June 1974.

(11) Currently inoperative. The 242-S Evaporator-Crystallizer was started up November 1973, and shut down March 1980, when its processing campaign was completed. It is in standby mode with no future mission. This evaporator operates under a vacuum, employing evaporitive concentration with subsequent crystallization and precipitation of salt crystals.

(12) Currently inoperative. The 242-A Evaporator-Crystallizer was started up March 1977, and shut down Apri1 1989 because of regulatory issues, and has remained shut down for subsequent upgrading. The restart schedule specifies January 4, 1993, as the projected start-up date. This evaporator operates under a vacuum, employing evaporative concentration with subsequent crystallization and precipitation of salt crystals (forming saltcake).

(13) Currently inoperative. Additional concentration of wastes was completed by using the concentrators at REDOX and B Plant. The REDOX concentrator was used from July 1967 to June 1972, while the B Plant concentrator was used from July 1967 to February 1968.

(14) Waste generated for training and testing purposes prior to Evaporator restart 
WHC-EP-0182-61

This page intentionally left blank.

D-6 
WHC-EP-0182-61

\section{APPENDIX E}

LIQUID STATUS AND PUMPABLE LIQUID

REMAINING IN TANKS 
WHC-EP-0182-61

This page intentionally left blank. 
WHC-EP-0182-61
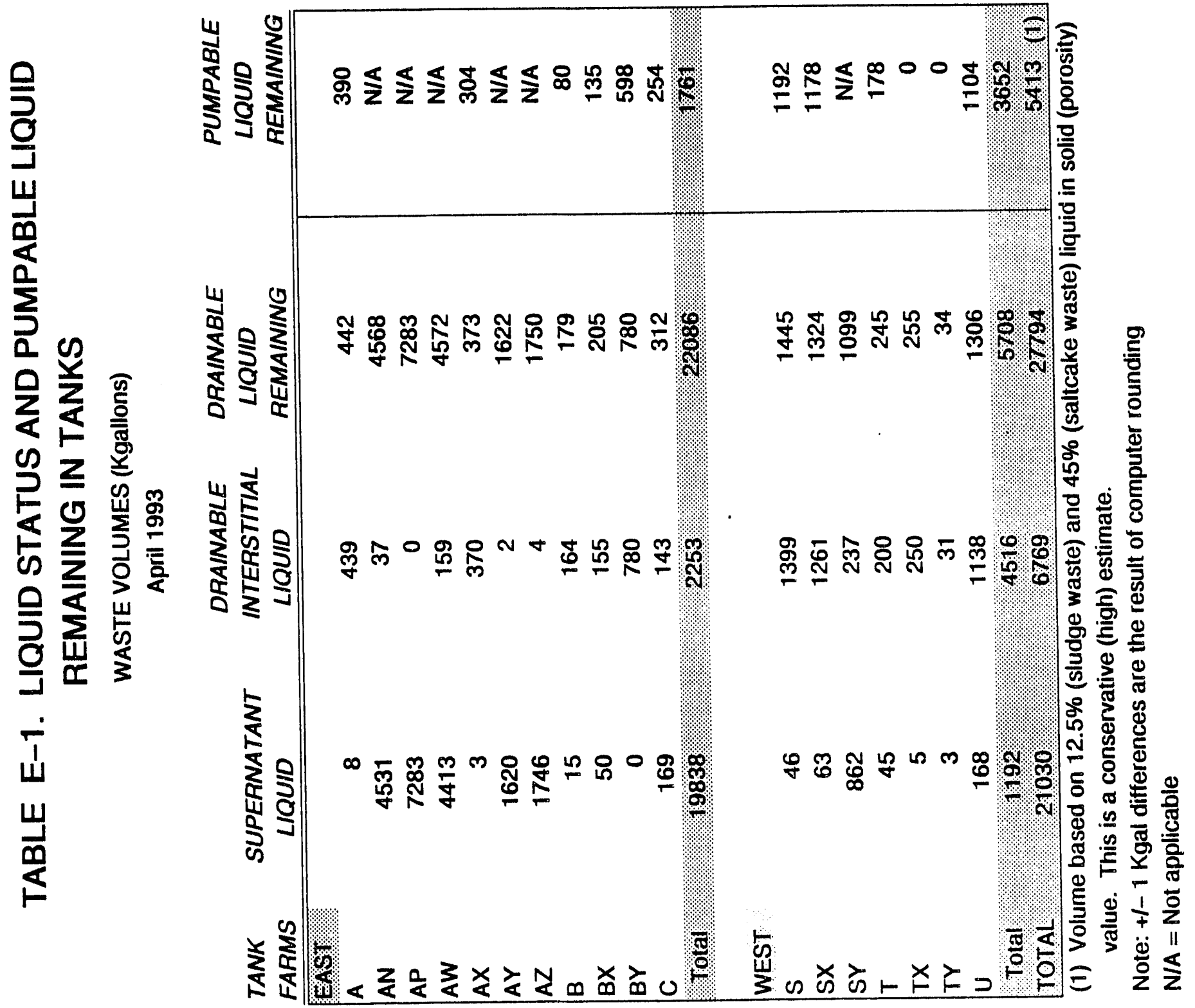
WHC-EP-0182-61

This page intentionally left blank.

E-4 
WHC-EP-0182-61

\section{APPENDIX F}

PUMPING RECORD

F-1 
WHC-EP-0182-61

This page intentionally left blank.

F-2 


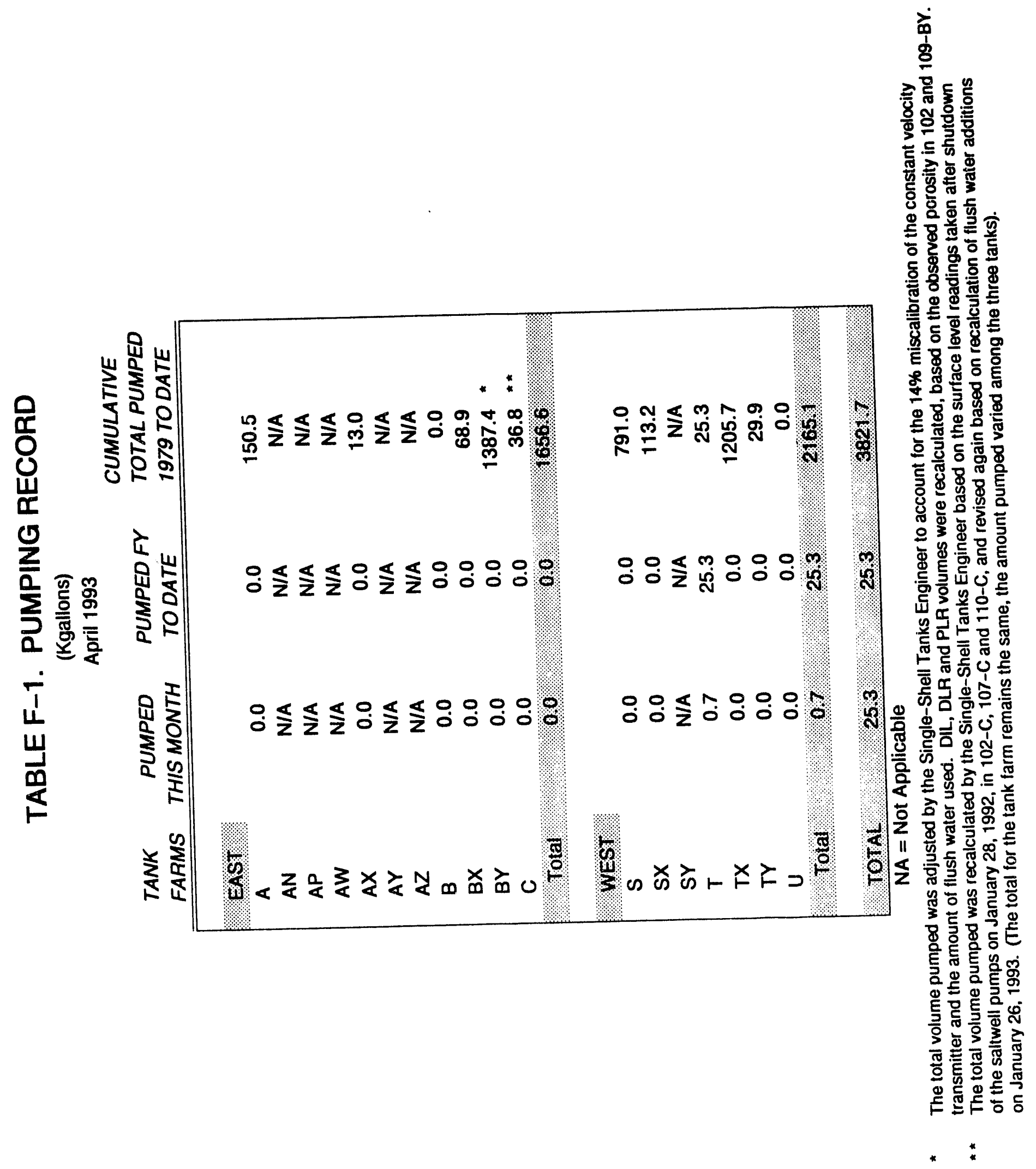


WHC-EP -0182-61

This page intentionally left blank.

$F-4$ 
WHC-EP-0182-61

\section{APPENDIX G}

CATCH TANKS AND SPECIAL SURVEILLANCE FACILITIES 
WHC-EP-0182-61

This page intentionally left blank. 


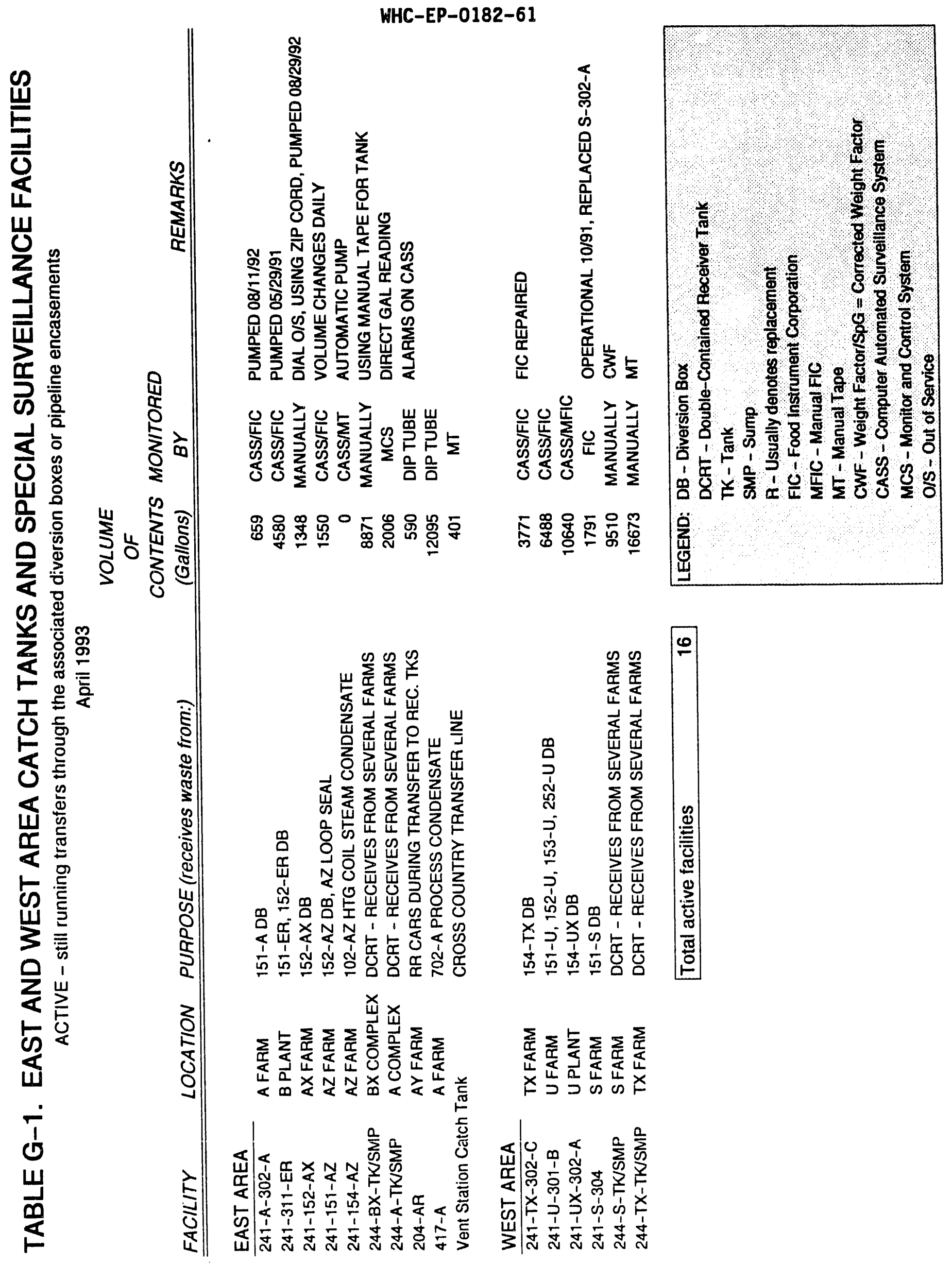

WHC-EP-0182-61 


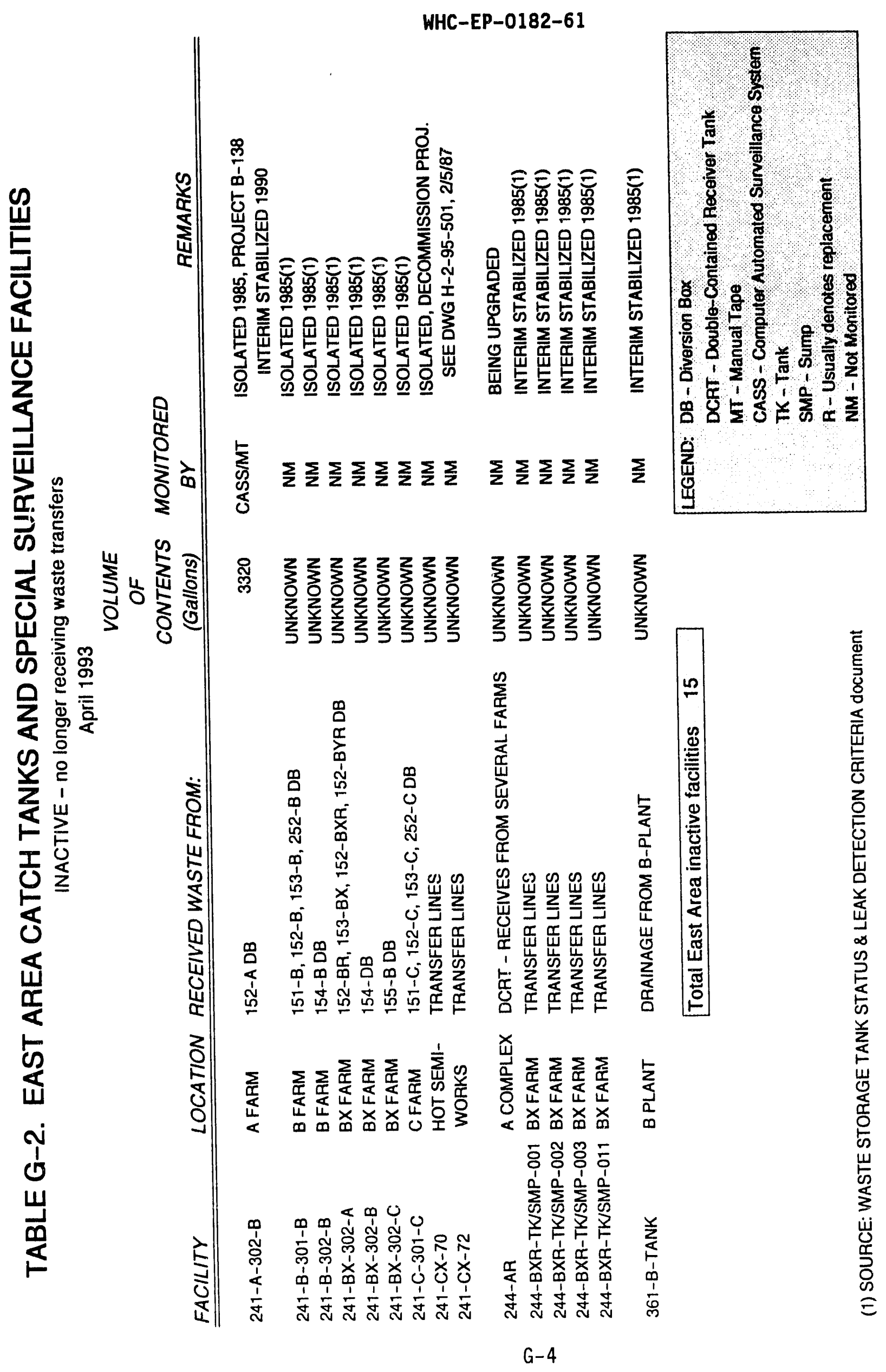




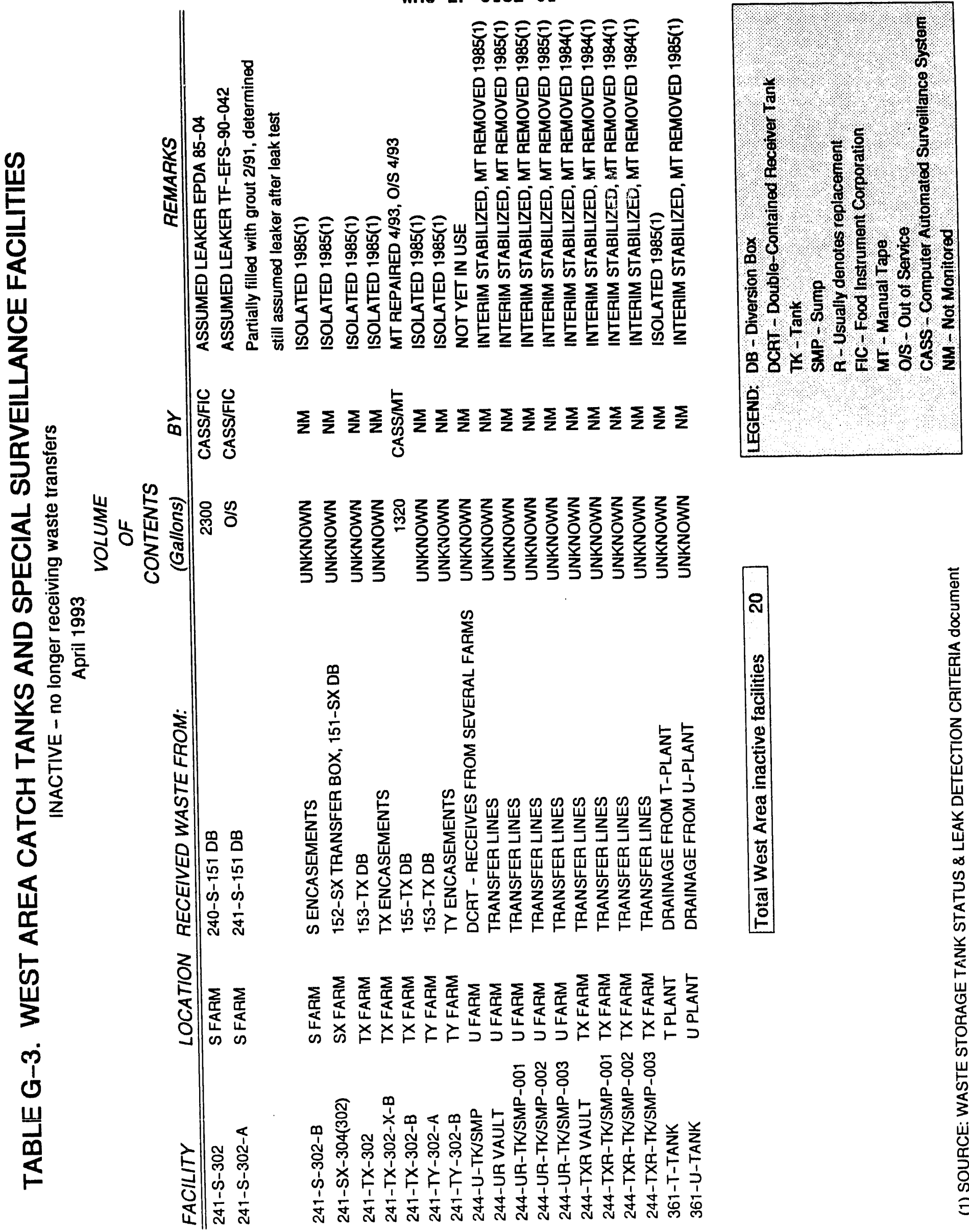




\section{WHC-EP-0182-61}

This page intentionally left blank.

G-6 
WHC-EP-0182-61

\section{APPENDIX H}

LEAK VOLUME ESTIMATES

H-1 
WHC-EP-0182-61

This page intentionally left blank.

$\mathrm{H}-2$ 
WHC-EP-0182-61

TABLE H-1. SINGLE-SHELL TANK LEAK VOLUME ESTIMATES (4) (Sheet 1 of 5)

Date Declared

Associated

\section{Interim}

Confirmed or

Volume (2)(4) KiloCuries

Stabilized

Tank No.

Assumed Leaker (3)

(Gallons)

241-A-103

$241-A-104$
$241-A-105$

(1)

1987
1975
1963

$137 \operatorname{cs}(10)$

Date

Leak Estimate

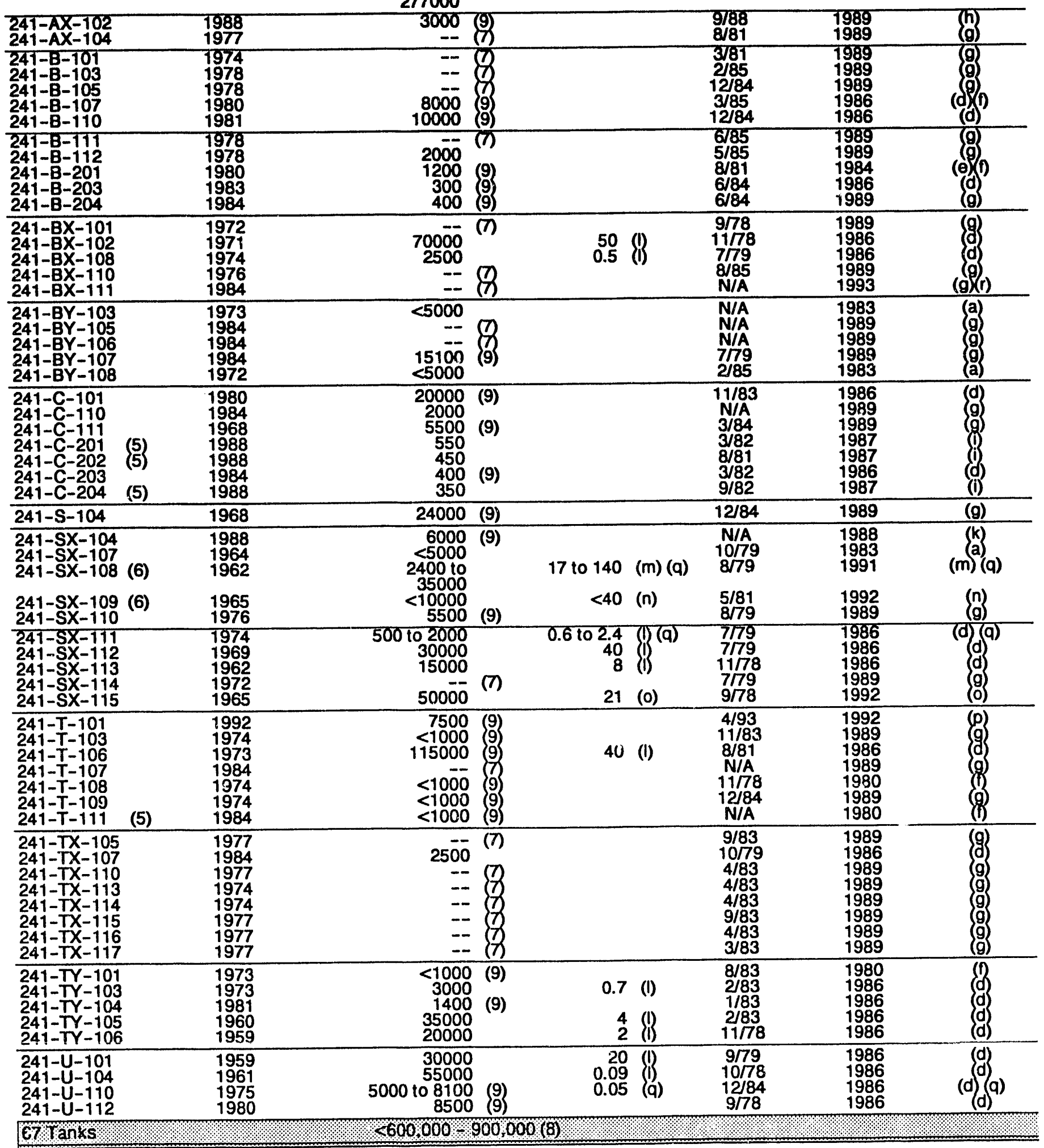

N/A = not applicable (not yet interim stabilized)

FOOTNOTES: SEE NEXT PAGE 
TABLE H-1. Single-She11 Tank Leak Volume Estimates

(Sheet 2 of 5 )

Footnotes:

(1) Current estimates (see reference b) are that $610 \mathrm{Kgal}$ of cooling water was added to Tank 241-A-105 from November 1970 to December 1978 to aid in evaporative cooling. In accordance with Dangerous Waste Regulations (Washington Administrative Code 173-303-070 (2)(a)(ii), as amended, Washington State Department of Ecology, 1990, 01ympia, Washington), any of this cooling water that has been added and subsequently leaked from the tank must be classified as a waste and should be included in the total leak volume. In August 1991, the leak volume estimate for this tank was updated and moved into compliance with the WAC regulations. Previous estimates excluded the cooling water leaks from the total leak volume estimates because the waste content (concentration) in the cooling water which leaked should be much less than the original liquid waste in the tank (the sludge is relatively insoluble). The total leak volume estimate in this report (10 Kgal to $277 \mathrm{Kgal})$ is based on the following (see References).

1. Reference (b) contains an estimate of $5 \mathrm{Kgal}$ to $15 \mathrm{Kgal}$ for the initial leak prior to August 1968.

2. Reference (b) contains an estimate of $5 \mathrm{Kgal}$ to $30 \mathrm{Kgal}$ for the leak while the tank was being sluiced from August 1968 to November 1970.

3. Reference (b) contains an estimate of $610 \mathrm{Kgal}$ of cooling water added to the tank from November 1970 to December 1978 but it was estimated that the leakage was small during this period. This reference contains the statement "Sufficient heat was generated in the tank to evaporate most, and perhaps nearly all, of this water." This results in a low estimate of zero gailons leakage from November 1970 to December 1978.

4. Reference (c) contains an estimate that 378 to $410 \mathrm{Kgal}$ evaporated out of the tank from November 1970 to December 1978. Subtracting the minimum evaporation estimate from the cooling water added estimate provides a range from 0 to $232 \mathrm{Kgal}$ of cooling water leakage from November 1970 to December 1978.

\section{Low Estimate $\quad$ High Estimate}

Prior to August 1968

August 1968 to November 1970

November 1970 to December 1978

Totals

$$
\begin{array}{r}
5,000 \\
5,000 \\
10,000
\end{array}
$$

$$
\begin{array}{r}
15,000 \\
30,000 \\
232,000 \\
\hline 277,000
\end{array}
$$

(2) These leak volume estimates do not include (with some exceptions), such things as: (a) cooling/raw water leaks, (b) intrusions (rain infiltration) and subsequent leaks, (c) leaks inside the lank farm but not through the tank liner (surface leaks, pipeline leaks, leaks at the joint for the overflow or fill lines, etc.), and (d) leaks from catch tanks, diversion boxes, encasements, etc. 
TABLE H-1. Single-Shell Tank Leak Volume Estimates

(Sheet 3 of 5 )

(3) In many cases, a leak was suspected long before it was identified or confirmed. For example, reference (d) shows that Tank 241-U-104 was suspected of leaking in 1956. The leak was "confirmed" in 1961. This report lists the "assumed leaker" date as 1961. Using present standards, Tank 241-U-104 would have been declared as assumed leaker in 1956. In 1984, the criteria designations of "suspected leaker," "questionable integrity," "confirmed leaker," "declared leaker," "borderline," and "dormant," were merged into one category now reported as "assumed leaker." See reference ( $f$ ) for explanation of when, how long, and how fast some of the tanks leaked. It is highly likely that there have been undetected leaks from single-shell tanks because of the nature of their design and instrumentation.

(4) There has been an effort in the past two years to reevaluate these leak volume estimates. During the FY 1993 funding reviews, this reevaluation of leak volumes was given a priority which resulted in this activity no longer being funded. The priority versus funding will be reevaluated as part of the prior to FY 1994 budget planning.

(5) The leak volume estimate date for these tanks is before the "declared leaker" date because the tank was in a "suspected leaker" or "questionable integrity" status; however, a leak volume had been estimated prior to the tank being reclassified.

(6) The increasing radiation levels in drywells and laterals associated with these three tanks could be indicative of a continuing leak or movement of existing radionuclides in the soil. There is no conclusive way to confirm these observations.

(7) Methods were used to estimate the leak volumes from these 19 tanks based on the assumption that their cumulative leakage is approximately the same as for 18 of the 24 tanks identified in footnote (10). For more details see reference $(\mathrm{g})$. The total leak volume estimate for these tanks is $150 \mathrm{Kgal}$ (rounded to the nearest $10 \mathrm{Kgal}$ ), for an average of approximately $8 \mathrm{Kgal}$ for each of the 19 tanks.

(8) The total has been rounded to the nearest $50 \mathrm{Kgal}$. Upperbound values were used in many cases in developing these estimates. It is likely that some of these tanks have not actually leaked.

(9) Leak volume estimate is based solely on observed liquid level decreases in these tanks. This is considered to be the most accurate method for estimating leak volumes.

(10) The curie content listed is as listed in the reference document and is not decayed to a consistent date; therefore, a cumulative total is inappropriate. 


\section{WHC-EP-0182-61}

TABLE H-1. Single-Shell Tank Leak Volume Estimates. (Sheet 4 of 5 )

References:

(a) Murthy, K.S., et al, June 1983, Assessment of Single-Shell Tank Residual Liquid Issues at Hanford Site, Washington, PNL-4688, Pacific Northwest Laboratory, Richland, Washington.

(b) WHC, 1991a, Tank 241-A-105 Leak Assessment, WHC-MR-0264, Westinghouse Hanford Company, Richland, Washington.

(c) WHC, 1991b, Tank 241-A-105 Evaporation Estimate 1970 Through 1978, WHC-EP-0410, Westinghouse Hanford Company, Richland, Washington.

(d) Smith, D. A., January 1986, Single-Shell Tank Isolation Safety Analysis Report, SD-WM-SAR-006, Rev. 1, Westinghouse Hanford Company, Rich1and, Washington.

(e) McCann, D. C., and T. S. Vail, September 1984, Waste Status Summary. RHO-RE-SR-14, Rockwell Hanford Operations, Richland, Washington.

(f) Catlin, R. J., March 1980, Assessment of the Surveillance Program of the High-Level Waste Storage Tanks at Hanford, Hanford Engineering Development Laboratory, Richland, Washington.

(g) Baumhardt, R. J., May 15, 1989, Letter to R. E. Gerton, U.S. Department of Energy-Richland Operations Office, Single-Shell Tank Leak Volumes, Westinghouse Hanford Company, Richland, Washington.

(h) WHC, 1990a, Occurrence Report "Surface Level Measurement Decrease in Single-She 11 Tank 241-AX-102," WHC-U0-89-023-TF-05, Westinghouse Hanford Company, Richland, Washington.

(i) Groth, D. R., July 1, 1987, Internal Memorandum to R. J. Baumhardt, Liquid Leve1 Losses in Tanks 241-C-201, -202 and -204, 65950-87-517, Westinghouse Hanford Company, Richland, Washington.

(j) Groth, D. R. and G. C. Owens, May 15, 1987, Internal Memorandum to J. H. Roecker, Tank 103-A Integrity Evaluation, Westinghouse Hanford Company, Richland, Washington.

(k) Campbe11, G. D., July 8, 1988, Internal Memorandum to R. K. Weity, Engineering Investigation: Interstitial Liquid Level Decrease in Tank 241-SX-104, 13331-88-416, Westinghouse Hanford Company, Rich1and, Washington.

(1) ERDA, 1975, Final Environmental Statement Waste Management Operations, Hanford Reservation, Richland, Washington, ERDA-1538, 2 vols., U.S. Energy Research and Development Administration, Washington, D.C.

(m) WHC, 1992a, Tank 241-SX-108 Leak Assessment, WHC-MR-0300, Hestinghouse Hanford Company, Richland, Washington.

(n) WHC, 1992b, Tank 241-SX-109 Leak Assessment, WHC-MR-0301, Westinghouse Hanford Company, Richland, Washington. 
TABLE H-1. Single-Shell Tank Leak Volume Estimates.

(Sheet 5 of 5 )

(0) WHC, 1992c, Tank 241-SX-115 Leak Assessment, WHC-MR-0302, Westinghouse Hanford Company, Richland, Washington.

(p) WHC, 1992d, Occurrence Report, "Apparent Decrease in Liquid Level in Single She11 Underground Storage Tank 241-T-101, Leak Suspected; Investigation Continuing," RL-WHC-TANKFARM-1992-0073, Westinghouse Hanford Company, Richland, Washington.

(q) WHC-1990b, A History of the 200 Area Tank Farms, WHC-MR-0132, Westinghouse Hanford Company, Richland, Washington.

(r) WHC, 1993, Occurrence Report, "Single-Shel1 Underground Waste Storage Tank 241-BX-111 Surface Leve1 Decrease and Change From Steady State Condition," RL-WHC-TANKFARM-1993-0035, Westinghouse Hanford Company, Richland, Washington. 

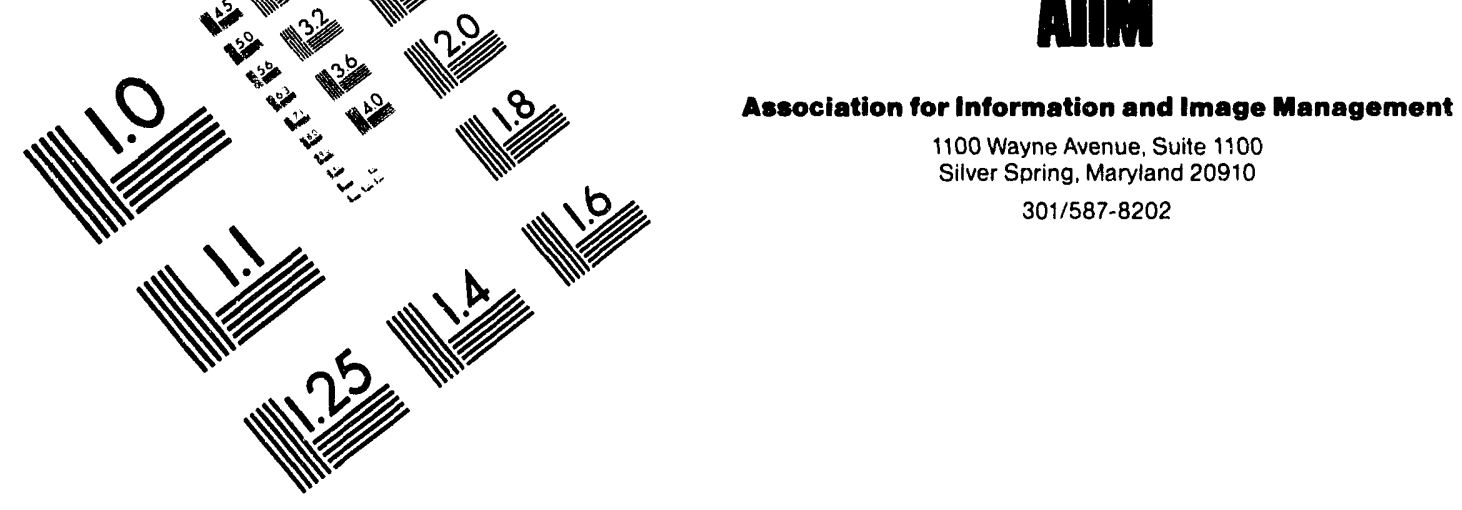

1100 Wayne Avenue, Suite 1100

Silver Spring, Maryland 20910

301/587-8202

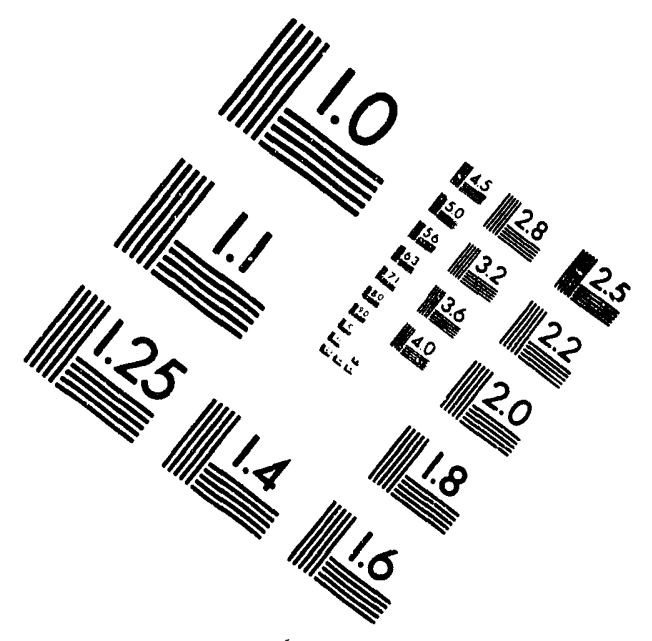

\section{Centimeter}

$\begin{array}{llllllllllllllll}1 & 2 & 3 & 4 & 5 & 6 & 7 & 8 & 9 & 10 & 11 & 12 & 13 & 14 & 15 & \mathrm{~mm}\end{array}$ Inches
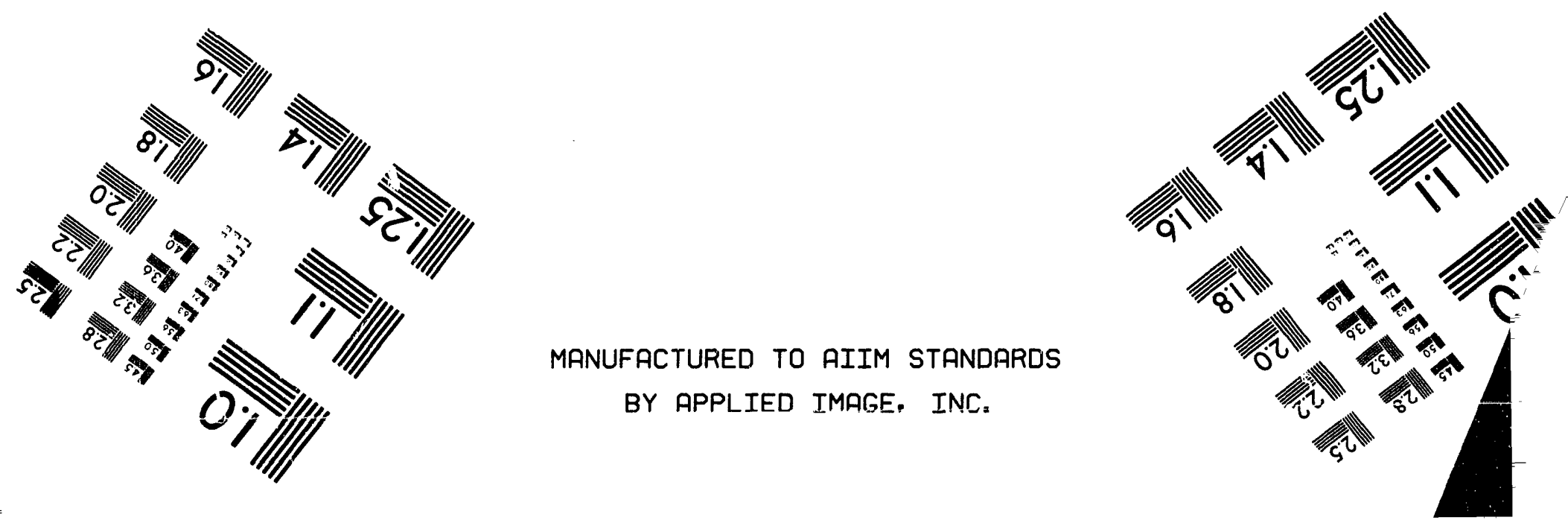

WHC-EP-0182-61

This page intentionally left blank. 


\section{DISTRIBUTION}

Number of copies

\section{OFFSITE - USA}

2

Congress of the United States

House of Representatives

1111 Longworth Building

Washington, DC 20515-3703

Ron Wyden, Member of Congress, 3rd District Josh Kardon, Legislative Director

U. S. Department of Energy-Headquarters 1000 Independence Avenue, SW Washington, D. C. 20585

\begin{tabular}{|c|c|c|c|}
\hline $\begin{array}{l}\text { Emile Bernard } \\
\text { H. Calley } \\
\text { H. Eckert } \\
\text { Teresa Fryberger } \\
\text { Sherry Gibson } \\
\text { A. Griffith } \\
\text { L. Gunn } \\
\text { D. Gupta } \\
\text { J. S. Kang } \\
\text { Kenneth Lang } \\
\text { J. C. Lehr } \\
\text { G. Mellinger } \\
\text { John Morrey } \\
\text { C. O'Dell } \\
\text { C. Pepson } \\
\text { J. C. Tseng } \\
\text { S. Woodbury }\end{array}$ & (Pac. & $\begin{array}{l}E M-50 \\
E M-36 \\
E M-36 \\
E M-542 \\
E M-55 \\
E M-322 \\
E M-36 \\
E M-36 \\
E M-351 \\
E M-36 \\
E M-442 \\
E M-36 \\
N W \text { Labs) } \\
E M-36 \\
E M-36 \\
E M-36 \\
\text { EH-222 }\end{array}$ & $\begin{array}{l}\text { TREV } \\
\text { TREV I I } \\
\text { TREV I I } \\
\text { TREV I I } \\
\text { TREV I I } \\
\text { TREV I I } / 343 \\
\text { TREV I I } \\
\text { TREV I I } \\
\text { TREV I I } / 368 \\
\text { TREV I I } \\
\text { TREV I I } / 160 \\
\text { TREV I I } \\
\text { TREV I I } \\
\text { TREV I I } \\
\text { TREV I I } \\
\text { TREV I I } / 366 \\
\text { FORS / } 3 G-092\end{array}$ \\
\hline
\end{tabular}

19901 Germantown Rd, Germantown, MD 20585
R. Lasky
EH-32.1
GTN/G-115
J. Psaras
NS-20 GTN
P. Worthington
NS-20 GTN

U. S. Department of Energy - Oak Ridge Operations Office P. 0. Box 2001 Oak Ridge, TN 37831

W. D. Adams EW-40 
WHC-EP-0182-61

Distribution - continued

U. S. Department of Energy - Savannah River Site P. 0. Box A

Aiken, SC 29808

C. Anderson

$707-\mathrm{H}$

Michael Chandler

$703-\mathrm{H}$

Mazen Shurrab

T. C. Temple

L. Sjostrom

W. R. West

V. Wheeler

$704-\mathrm{H}$

704-8H

704-S

U. S. Department of Energy - Idaho Operations 785 D. 0. E. Place Idaho Falls, ID 83402

W. Sato

MS-11-18

1

U. S. Environmental Protection Agency

Region 10

712 Swift Boulevard, Suite 5

Richland, WA 99352

P. T. Day

Washington State Department of Ecology

Nuclear \& Mixed Waste Management Program

P.0. Box 47600

01ympia, WA 98504-7600

M. T. Gordon

M. Lerchan

Scott McKinney

R. Stanley

Library

7601 W. Clearwater \#102

Kennewick, WA 99336

S. V. Moore

Office Library

Washington State Departinent of Health

Radiation Protection Section

Industrial Park Building 5, LE-13

Olympia, WA 98504

A. Conklin

General Accounting office

P. 0. Box 321

Richland, WA 99352

C. R. Abraham 
WHC-EP-0182-61

Distribution - continued

1

Oregon State Department of Energy

625 Marion St. N.E.

Salem, OR 97310

Janet Franco

1

Oregon State Water Resources Department Ground Water Hanford Studies 3850 Portland Road

Salem, OR 97310

R. 0. Patt

1

Lawrence Livermore National Laboratory

Box 808, East Avenue

Livermore, CA 94550

B. C. Hudson

$L-221$

4

Oak Ridge National Laboratory

P. 0. Box 2009

Oak Ridge, TN 37831-6385

C. Forsberg

MS-6495

T. S. Kress

MS-8088

B1dg 9108

Chemical Technology Division

P. 0. Box 2008

Emory D. Collins

C. Phil McGinnis

6

Los Alamos National Laboratory

P. 0. Box 1663

Los Alamos, NM 87545

Stephen Agnew

Group INC-14

Phyll is Baca

$C-346$

T. Larson

Sylvia Lee

A. Nuels

H. Sullivan

$\mathrm{J}-514$

C-915

$\mathrm{K}-557$

$\mathrm{N}-6$

$N-6$

Brookhaven National Laboratory Upton, NY 11973

K. K. Bandyopadhyay, B7dg 475-C

M. K. Kaisser, B1dg 475-C

P. D. Kalb, Bidg. 703

M. Reich, Bldg 475-C

J. R. Weeks, B1dg 197-C 
WHC-EP $\approx 0182-61$

Distribution - continued

Brookhaven National Laboratory

1409 Jan Drive

Wilmington, DE 19803

Michael Streicher

2

Sandia Nationai Laboratories

1515 Eubank, NE

P. 0. Box 5800

A1buquerque, NM 87185

Scott Slezak, Division 6402

Leon D. Chapman, Program Manager

Industrial Waste Reduction Program

1

Massachusetts Institute of Technology

77 Massachusetts Avenue

Cambridge, MA 02139

Mujid S. Kazimi

Professor and Head

Department of Nuclear Engineering

2

BDM International. Inc.

20030 Century BTvd, Suite 101

Germantown, MD 20874

P. Kiang

K. J. Hahoney

3

SAIC

20300 Century Bivd.

Germantown, MD 20874

J. Bunting

J. R. Pearring

R. A. Wull aert

1

102 Windham Road

Oak Ridge, TN 37830

D. 0. Campbe11

1

SAIC

$\frac{\text { SAIC }}{1845}$ Terminal Drive, Suite 130

Richl and, WA 99352

J. Mishima

1

Harvard School of Public Health

665 Huntington Avenue

Boston, MA 02115

M. First 
WHC-EP-0182-61

Distribution - continued

Confederated Tribes, Umatilla Indian Reservation P. 0. Box 638

Pendleton, OR 97801

Rick George

West Valley Nuclear Services Co.

P. 0. Box 191

West Valley, NY 14171

K. K. Gupta

S. Ketola

MS -49

D. K. Ploetz

MS -191

Ram Shukla

Don Stroud

MS-305

4

Defense Nuclear Facilities Safety Board 625 Indiana Ave, N. W., Suite 700 Washington, D. C. 20004

Dan Burnfield

Lester Clemons Suite 700

Paul Gubanc Suite 700

Dermot M. Winters, Geological Engineer

2

Westinghouse Idaho Nuclear Corporation

P. 0. Box 4000

Idaho Falls, ID 83403-4000

B. Griebenow

MS-5104

A. P. Hoskins

MS -5217

1

C. Abrams

1987 Virginia Drive

Idaho Fails, ID 83404

1

F. Carlson

6965 North, 5th West

Idaho Falls, ID 83401

1

D. Oakley

40912 th Street, SW, \#310

Washington, D. C. 20024

1

Dr. A. Veletsos

Department of Civil Engineering

Rice University

P. 0. Box 1892

Houston, TX 77252 
WHC-EP-0182-61

Distribution - continued

Westinghouse Electric Corporation

1801 K Street NW, 8th floor

Washington DC, 20006

Kevin Billings

Westinghouse Materials Company of Ohio

P. 0. Box 398704

Cincinnati $\mathrm{OH} 45239-8704$

David L. Jacoboski

Senior Engineer, Technology Demonstration

4

Westinghouse Savannah River Company

P. 0. Box 616

Aiken, SC 29802

D. M. Barnes, 773-41A

J. R. Chandler, 703-H

P. d'Entremont

F. G. McNatt, 704-8A

Institute for Energy and Environmental Reseach

6935 Laurel Avenue

Takoma Park, MD 20912

Dr. Arjun Makhijani, President

SPAR Aerospace Ltd.

20 Avon Meadow Lane, Suite 220

Avon, CT 06001

Peter W. Kruse

Advanced Technology Systems Division

Redzone Robotics, Inc.

2425 Liberty Ave

Pittsburgh, PA 15222-4639

David W. White

National Research Council, National Academy of Sciences 2101 Constitution Ave., N. W. Washington D. C. 20418

Robert S. Andrews, Senior Staff officer

Board on Radioactive Waste Management

1 Converse Consultants

18 W. Mercer Street, Suite 300

Seattle, WA 98119

David Stanley 


\section{Distribution - continued}

1

1

1

1

1

1

1

1

1
Brown \& Caldwe11

$100 \mathrm{~W}$. Harrison

Seattle, WA 98119

Hal Cooper

Benton County Department of Emergency Management

P.0. Box 6144

Kennewick, WA 99336

Gary Pira

BOVAY Northwest Inc.

660 Swift, Suite D

Rich1 and, WA 99352

T. J. McLaughl in

Omega Environmental Technology

655 Montgomery Street, Suite 1000

San Francisco, CA 94111

Mike Bailey

GEC ALSTHOM Engineering Systems

P. 0. Box 1274

Richland, WA 99352

J. W. Riddington,

Vice President, Nuclear Marketing

T. S. Elleman

North Carolina State University

Department of Nuclear Energy

P. 0. Box 7909

Raleigh, NC 27606

Mike Lingle

Stone \& Webster

7677 E. Berry Ave

Englewood, CA 80111

Bryant Mather

Corps of Engineers

WESSV-Z

$3909 \mathrm{Ha} l 1 \mathrm{~s}$ Ferry Rd

Vicksburg, MS 39180-6199

Paul Shewmon

Prof. Metallurgical Engineer

Ohio State University

2477 Lytham Road

Columbus, $\mathrm{OH} 43220$

Distr-7 
WHC-EP-0182-61

Distribution - continued

Waste Management External Advisory Committee Members

Dr. Frank L. Parker

Professor of Environmental and Water Resources Engineering Vanderbilt University

P. 0. Box 1596, Station B

Nashville, TN 37235

Dr. Bruce R. Kowalski

Professor of Chemistry, Co-director of Center for Process

Analytical Chemistry

University of Washington

Chemistry Department, B1dg 10

Seattle, WA 98195

Dr. Greg R. Choppin

Professor of Chemistry

Florida State University

Department of Chemistry, B-164

Tallahassee, FL 32306

Dr. Chester Grelecki

President, Chief Scientist

Hazards Research Corporation

200 Valley Road

Mt. Arlington, NJ 07856

Dr. Alfred Schneider

MIT Department of Nuclear Engineering

Room 24-1098

77 Massachusetts Avenue

Cambridge, MA 02139

Dr. Gary Powers

President

Design Science, Inc.

163 Witherow Road

Sewickley, PA 15143

2

Ames Laboratory

7 Spedding $\mathrm{Ha} 11$

Iowa State University

Ames, IA 50011

Bill Haas

R. B. Thompson

RKK Ltd.

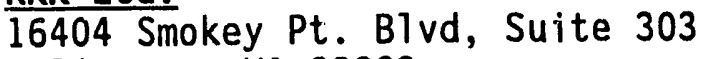

Arlington, WA 98223

Chris Reno 
WHC-EP-0182-61

Distribution - continued

1

MACTEC

8320 Centerbrook Place

Alexandria, VA 22308

Stan Blacker

1

Engineering-Science, Inc.

1955 Jadwin Ave, Suite 470

Richland, WA 99352

Matt Sakach

1

EBASCO Services, Inc.

1201 Jadwin Avenue, Suite 202

Richland, WA 99352-3429

F. J. Young

1

MTL Systems, Inc.

3481 Dayton-Xenia Road

Dayton, OH 45431-0299

E. McDaniel

1

Nuclear Consulting Services, Inc. 7000 Huntley Road

P. 0. Box 29151

Columbus, $\mathrm{OH} 43229$

Dr. J. Louis Kovach

1

Battelle Laboratories

505 King Avenue

Columbus, $\mathrm{OH}$ 43201-2693

Rob Taylor Jr., P.E.

Rm 13-6-016

1

Portland General Electric Co.

121 S. W. Salmon St.

Portland, OR 97204-2991

Wayne Lei, 3WTCBRO5

1

NORCON

7000 Huntley Road

P. 0. Box 29151

Columbus, $\mathrm{OH} 43229$

P. Kovach 
WHC-EP-0182-61

Distribution - continued

JOHN HOPKINS UNIVERSITY

1714 Eutaw Place

Baltimore, MD 21217

Morton Corn

\section{OFFSITE - FOREIGN}

1

British Nuclear Fuels Ltd

Risley Warrington

Cheshire WA3 6AS

United Kingdom

Howard A. Edwards

1

Ricardo Hitec Ltd

Club street Works, Bamber Bridge Preston, PR5 6FN

United Kingdom

P. K. J. Smith

1

Telerobot

Consorzio Telerobot

Via Hermada 6

16154 Genova, Italy

Bruno Sessarego

1

SGN

1 , rue des Herons, Montigny-C-Bretonneux

78132 Saint-Quentin-en-Yvelines Cedex,

France

Serge Merlin

2

CEA - Saclay

DCC/DIR

$\mathrm{Ba} t ! 21$

$91190 \mathrm{GIF} /$ Yvette Cedex

France

G. Baudin

R. Atabek

1

Hans Wal ischmiller GmbH

D-7778 Markdorf/Bodensee

Germany

Wolfgang Wal ischmiller 
WHC-EP-0182-61

Distribution - continued

ONSITE

24

U. S. Department of Energy-Richland Operations Office

G. E. Bishop

R3-72

K. W. Bracken

R3-73

G. J. Bracken

R3-72

S. T. Burnum

R3-74

N. R. Croskrey

R1-30

R. C. Cullison

A5-55

J. J. Davis

R3-74

L. Erickson

R3-74

R. E. Gerton

R3-72

W. F. Hendrickson

R3-72

R. D. Hildebrand

A5-55

P. E. LaMont

R3-74

T. Noble

R3-72

R. L. Person

R3-72

L. E. Petersen

G. W. Rosenwald

R3-72

G. H. Sanders

R3-72

E. J. Senat

R3-74

J. B. Sullivan

R3-72

A. D. Toth

A5-10

W. R. Wrzesinski

R3-72

R3-74

J. K. Yerxa

A5-15

Reading Room

Al -65

Kaiser Enginsering Hanford
S. A. Davidson
K6-26
C. J. Denson
E6-51
J. E. Fasso Jr.
S3-10
A. L. Huegel
E6-31
K. I. Corbin
R] -51
R. L. Newell
E6-31
D. J. Shrimpton
E6-21

Stone \& Webster Engineering Co.
E. L. Richards
R2-83

2

MACTEC

J. Janus

G6-18

L. Soler

A4-35

Pacific Northwest Laboratories
D. B. Baird
K7-34
D. W. Bennett
K5-22
S. A. Bryan
PT -25
L. L. Burger
P7-25 


\section{Distribution - continued}

$\begin{array}{ll}\text { J. F. Fletcher } & \text { K7-97 } \\ \text { L. K. Holton Jr. } & \text { P7-43 } \\ \text { J. Janata } & \text { K2-12 } \\ \text { B. M. Johnson } & \text { K1-78 } \\ \text { E. O. Jones } & \text { P8-38 } \\ \text { L. G. Morgan } & \text { P7-35 } \\ \text { B. E. Opitz } & \text { K6-81 } \\ \text { M. S. Peffers } & \text { K7-94 } \\ \text { W. G. Richmond } & \text { P7-41 } \\ \text { R. D. Scheele } & \text { P7-25 } \\ \text { E. A. Schmieman } & \text { K6-14 } \\ \text { P. A. Scott } & \text { P7-19 } \\ \text { J. C. Spanner } & \text { K2-05 } \\ \text { D. Strachan } & \text { K2-38 } \\ \text { K. L. Steinmaus } & \text { K6-84 } \\ \text { R. S. Wegeng } & \text { K7-97 } \\ \text { P. D. Whitney } & \text { K7-34 } \\ \text { T. W. Wood } & \text { K6-47 }\end{array}$

Westinghouse Hanford Company
A. T. Alstad
R1-49
R. P. Anantatmula
R2-11
J. D. Anderson
J. N. Appel
N3-11
I. J. Austin
S4-58
H. Babad
T4-01
J. K. Bajwa
R2-78
$\mathrm{H} 4-63$
A. D. Bates
T6-07
P. K. Bhatia
S4-58
T. J. Bander
$\mathrm{HO}-33$
L. L. Barry
R1-67
G. D. Bazinet
L4-71
D. L. Becker
H5-57
D. B. Bechtold
T6-09
K. H. Bergsman
L6-24
M. V. Berriochoa
B3-30
D. L. Bjorklund
S6-01
J. E. Bjorklund
R1-62
R. J. BT anchard
R1-17
D. C. Board
S1-57
K. D. Boomer
H5-49
G. L. Borsheim
R2-11
V. C. Boyles
R1-49
H. R. Brager
L5-65
D. R. Bratzel
L5-31
R. G. Brown
R2-14
J. G. Burk, Jr.
B3-25
T. M. Burke
S4-58
S. K. Burden
S4-55
J. H. Bussell
L7-06
J. A. Caggiano Jr
H6-06
K. G. Carothers
R1-51
J. W. Carey
SO-01 


\section{Distribution - continued}

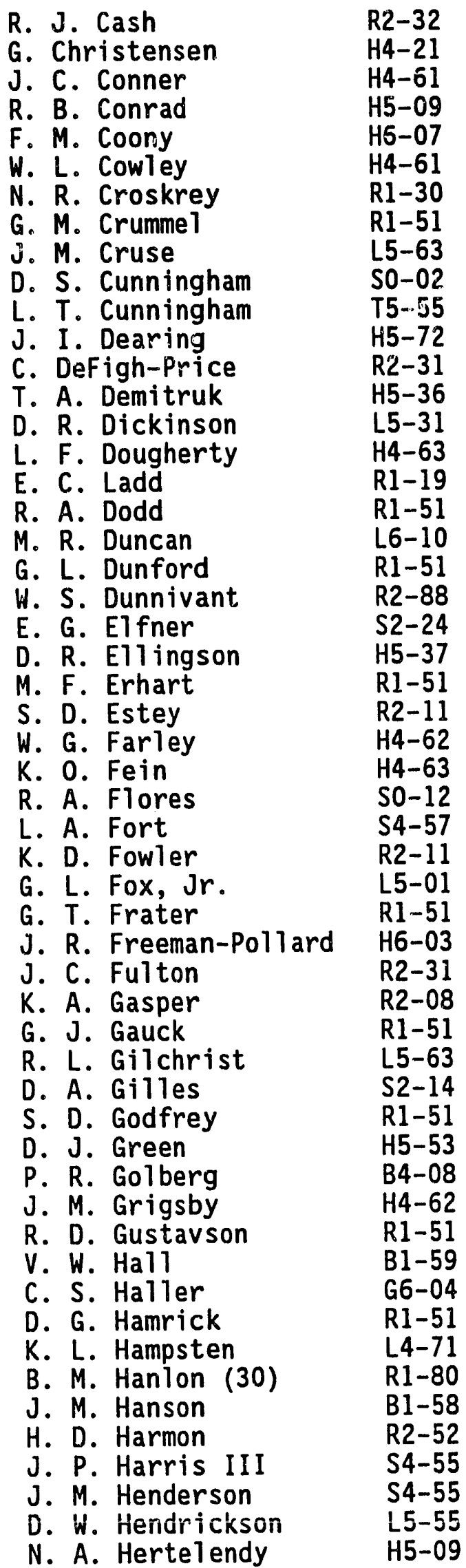




\section{Distribution - continued}

E. G. Hess

M. C. Higginson

J. G. Hi11

B. M. Hisaw

M. J. Holm

J. D. Hopkins

B. K. Horsager

R. D. House

J. H. Huber

J. L. Huckaby

L. L. Humphreys

J. E. Hysjutien

J. E. Irwin

M. N. Islam

G. D. Johnson

J. L. Juette

L. J. Julyk

R. A. Kirkbride

N. W. Kirch

W. L. Knecht

G. M. Koreski

A. G. Krasopoulos

M. Kummerer

M. J. Kupfer

D. R. Lance

D. L. Lenseigne

D. C. Lini

P. J. Mackey

G. T. MacLean

M. K. Mahaffey

R. M. Marusich

V. D. Maup in

T. B. McCall

J. D. McCormack

K. S. McCullough

M. E. McDonald

M. A. McLaughl in

J. P. Menard

W. C. Miller

N. J. Milliken

W. J. Millsap

G. J. Miskho

J. R. Mobley

T. Moleff

K. L. Morris

J. P. Mullally

L. D. Muhlestein

A. F. Noonan

T. W. Oden

P. C. Ohl

D. B. Pabst

R. B. Pan

I. G. Papp

L. D. Parchen
R3-09

A4-25

R2-12

R1-62

R1-80

R2-11

B5-24

R2-83

R1-49

R2-i1

R2-50

S0-09

B1-59

R3-08

R2-78

G6-56

H5-56

S4-58

R2-11

HO-34

R1-51

A5-55

H4-62

H5- 49

SO-09

R2-75

H5-49

B3-15

S4-58

ᄂ4-73

H4-60

R1-51

HO-33

L5-31

H5-34

X3-68

H5-09

R2-40

S4-55

H4-62

H5-68

R2-50

R2-18

H5- 09

H5- 09

B5-24

N1-28

R2-12

R2-18

H5- 03

B2-35

H5-53

R3-45

B3-63 


\section{Distribution - continued}

\begin{tabular}{|c|c|}
\hline 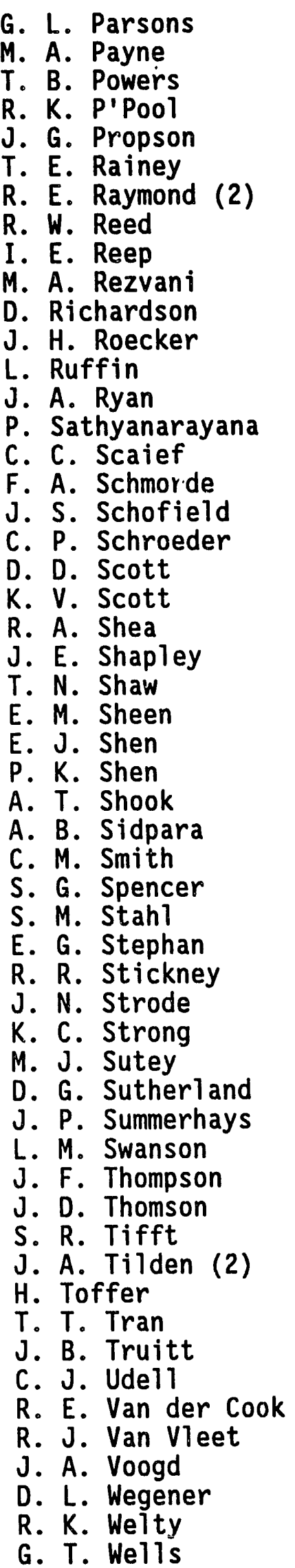 & 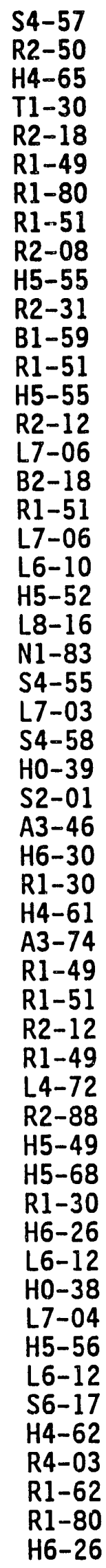 \\
\hline
\end{tabular}


WHC-EP-0182-61

\section{Distribution - continued}

K. A. White

D. D. Wodrich

B. D. Zimmerman

Docket File (2)

272-AW Shift Office

Central Files (2)

Tank Farms Info Center R1-28

Information Release

Administration (3)

Env Data Mgmt Center
$\mathrm{R} 1-51$

B1-59

LO-06

H5-36

S5-04

L8-04

R1-08

H4-22 

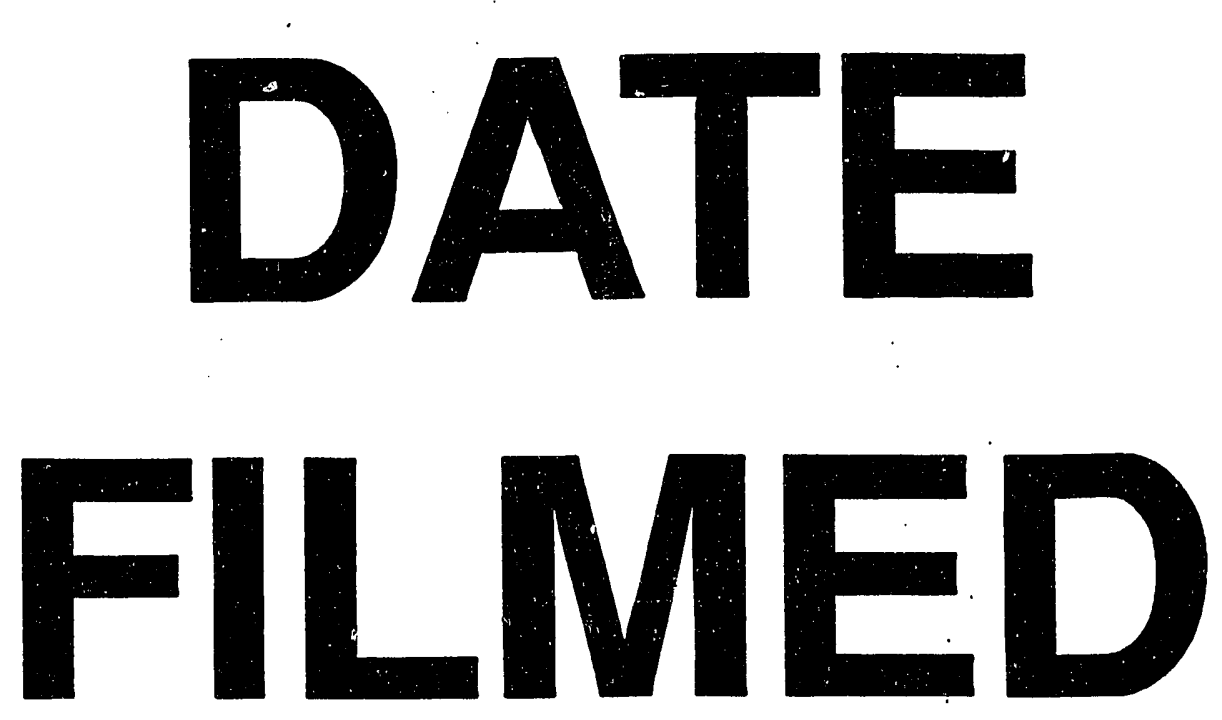

$9 / 28 / 93$
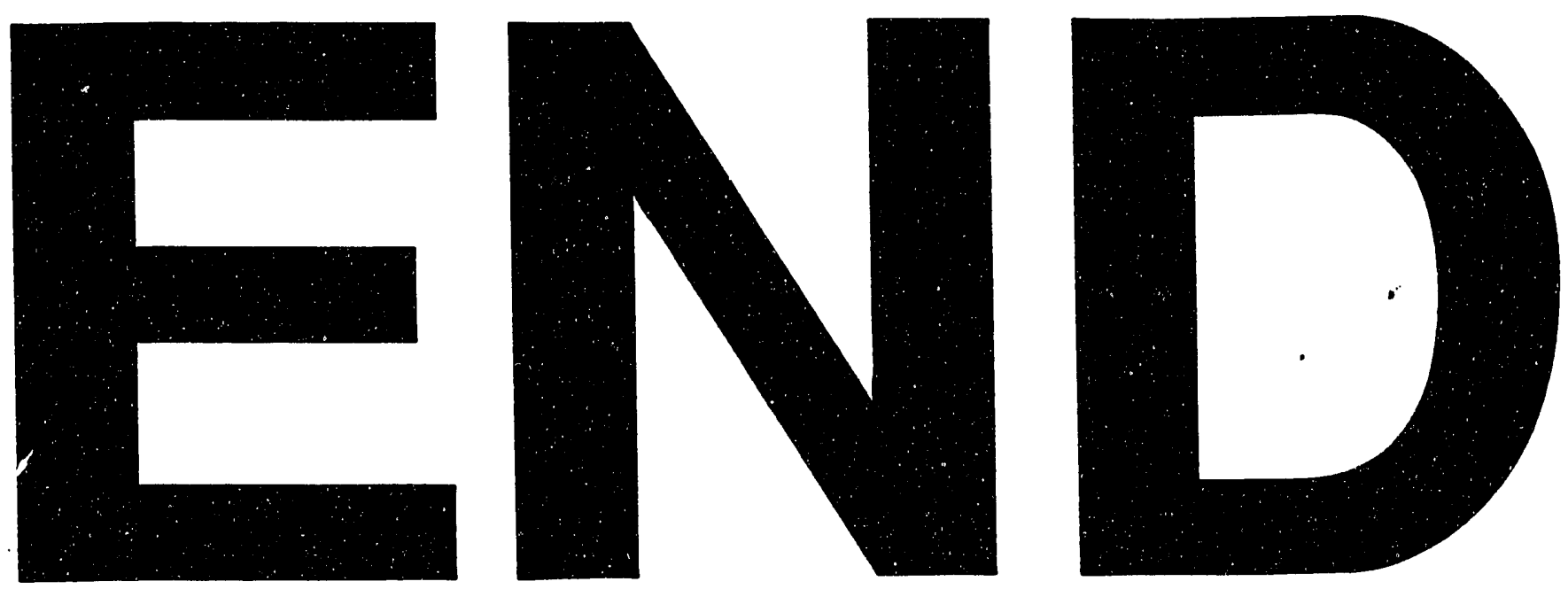
